





\section{Columbia Olnibersity}

STUDIES IN CLASSICAL PHILOLOGY

THE DREAM

IN

HOMER AND GREEK TRAGEDY 


\section{COLUMBIA UNIVERSITY PRESS}

SALES AGENTS

NEW YORK

LEMCKE \& BUECHNER

30-32 West 27th StreEt

LONDON

HUMPHREY MILFORD

AMEN Corner, E. C.

SHANGHAI

EDWARD EVANS \& SONS, LTD.

30 North Szechuen Road 


\title{
THE DREAM
}

IN

\section{HOMER AND GREEK TRAGEDY}

\author{
BY \\ WILLIAM STUART MESSER \\ INSTRUCTOR IN CLASSICAL PHILOLOGY, BARNARD COLLEGE \\ COLUMBIA UNIVERSITY
}

Submitted in Partial Fulfilment of the Requirements for the Degree of Doctor of Philosophy, in the

Faculty of Philosophy, Columbia University

\author{
Fem 国ork \\ COLUMBIA UNIVERSITY PRESS \\ 1918 \\ All rights reserved
}




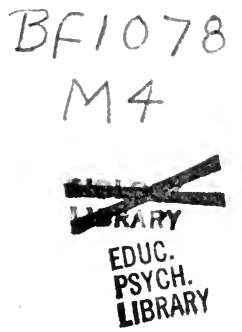

Copyright, 1918

By Columbia University Press

Printed from type, April, 1918

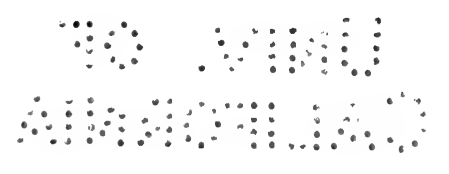




\section{NOTE}

This monograph has been approved by the Department of Classical Philology of Columbia University as a contribution to knowledge worthy of publication.

Clarence H. Young, Chairman. 



\section{- PREFACE}

This treatise is part of a broader investigation of the dream in all its aspects, literary and non-literary, to which I have devoted the spare hours of the last seven years. My primary interest in this investigation has been in the dream and its ways in Latin literature. A study published in Mnemosyne, 45, 7892 , in which I suggested a possible source for one feature of a certain type of Roman dream, may be taken as defining to some extent my interest in the dream from the literary standpoint as well as presenting my conclusions with respect to the problems involved in the particular dream considered in that study. But to treat adequately the dream in Latin literature presupposes a knowledge of its ancestor and prototype in Greek literature, and so the present introductory monograph embodies one phase of my researches in the earlier field. It discusses some aspects of the dream in a portion of that field-Homer, Hesiod and Greek Tragedy. It concerns itself with the dream as an originating cause or directing principle of the action in poem or play, a moving force in the evolution of narrative or plot and in the introduction of smaller incidents and episodes. An American scholar ${ }^{1}$ has recently complained of the lack of a proper study of the matter of motivation in Greek and Latin tragedy and comedy. This essay touches upon a limited portion of that larger investigation. From another point of view it deals, within the limits of each dream picture, with the amplification of the dream, its increasing complexity, its growth and refinement, or its decay, as an artistic literary device. I hope at no far distant date to publish further studies in other aspects of the dream.

${ }^{1} \mathrm{H}$. W. Prescott, Classical Philology, 11, 136; 141. 
I believe that few of the discussions of the dream, generally accessible, have escaped my examination. Furthermore, I have made a collection of the passages in Greek and Latin literature in which dreams are related in full or in which reference is made to dreams, scarcely short of entire completeness, down through the first quarter of the second century, so that on any point the guiding principle of a knowledge of how the dream has been treated elsewhere has always been available. On the basis of this reading I have, in the footnotes, defended positions taken in the text and discussed allied aspects of the dream, contenting myself, however, with the citation of authorities and parallel passages which may be looked upon as illustrative rather than as exhaustive.

The study of the art and the structure of poetry concerns itself with a great number of smaller problems of technique, of which that involved in the use of the dream is one. The solution of the problems of the technique of the dream, then, will to some extent throw light upon that larger field.

William Stuart Messer.

Barnard College, Columbia University. June 4, 1917. 


\section{CONTENTS}

HOMER . . . . . . . . . . . . . . 1-52

The Iliad . . . . . . . . . . . . . . . . 1

The Odyssey . . . . . . . . . . . . . . . 24

Summary for the Homeric Poems . . . . . . . 47

Hesiod . . . . . . . . . . . . . . . . 53

Tragedy . . . . . . . . . . . . . . 56-102

Aeschylus . . . . . . . . . . . . . 60

The Persae . . . . . . . . . . . . . . 60

The Prometheus Vinctus . . . . . . . . . 66

The Choephori . . . . . . . . . . . . 70

The Eumenides . . . . . . . . . . . 74

Minor References . . . . . . . . . . . 77

SOPHOClES . . . . . . . . . . . . . . . . 79

The Electra . . . . . . . . . . . . . . 79

Euripides . • • • • • • . . • . . . . . 85

The Hecuba . • • • • . . . . . . . 85

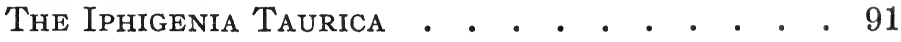

The Rhesus . . . . . . . . . . . . 97

Minor References . . . . . . . . . 100

List of AbBreviations: Bibliography . . . . . . 103 

THE DREAM IN HOMER AND GREEK TRAGEDY

\section{HOMER}

\section{THE ILIAD ${ }^{1}$}

The early conception of the dream was, as is shown by the language, extremely simple. Homeric vocabulary gives no hint of an elaborate classification, under the general term 'dream', of many types of experiences, all closely related to the experiences of the dream and yet differing from one another, such as gradually took shape and, at a later period, was widely known. ${ }^{2} /$ This classification appears in Artemidorus, Macrobius, Ioannes Saresberiensis, who all drew from a common source, and in

'For greater clearness in reference I have relegated to a List of Abbreviations, arranged alphabetically (pages 103-105), the titles of works cited two or more times. In all other cases the necessary identification will be found in the footnotes.

${ }^{2}$ The ancient classical writers on dreams and dream interpretation were legion. The chief sources for a list of them are Cicero, De Divinatione; Artemidorus, Onirocritica; Tertullian, De Anima (the earliest treatise on Christian psychology). Büchsenschütz, 47-52, gives a list of those who followed the classical period, with a short summary of the contributions of each: Antiphon, an Athenian of the time of Alexander; Straton, a pupil of Theophrastus; Demetrius of Phalerum; Aristandrus and Apollodorus of Telmessus; Philochorus, the historian; Chrysippus; Antipatrus of Tarsus; Dionysius of Rhodes; Cratippus, the Peripatetic; Alexander of Myndus; Hermippus of Berytus; Apollonius of Attaleia; Artemon of Miletus; Geminus of Tyre; Nicostratus of Ephesus; Phoebus of Antioch; Serapion of Ascalon. From these and all other sources, Artemidorus felt himself called upon by Apollo, so he declares, 2, 70, to collect material for the compilation of a comprehensive treatise, a definitive account of the dream and its interpretation. The subject-matter and the theoretical. beliefs of his predecessors are very largely preserved in his five books. 
Nicephorus Gregoras and Pseudo-Augustinus, ${ }^{3}$ who find their archetype in the writings of Macrobius. ${ }^{4}$ Macrobius' discussion is the most famous. He gives the list as follows (Somnium Scipionis, 1, 3, 2): aut enim est öveıpos secundum Graecos quod Latini somnium vocant, aut est öp $\alpha \alpha$ quod visio recte appellatur, aut est $\chi p \eta \mu \alpha \tau \iota \sigma \mu o ́ s$ quod oraculum nuncupatur, aut est évú $\pi \nu$ iov quod insomnium dicitur, aut est $\phi \alpha \dot{\nu} \tau \alpha \sigma \mu \alpha$ quod Cicero, quotiens opus hoc nomine fuit, visum vocavit. Plainly, all these conceptions, once fairly distinct, had by the time of Macrobius been merged in the general idea of dream. But in Homer, three of these words, öp $\alpha \mu \alpha, \chi p \eta \mu \alpha \tau \imath \sigma \mu \delta ́ \varsigma, \phi \dot{\alpha} \nu \tau \alpha \sigma \mu \alpha$, nowhere occur. Évú $\pi$ viov is found in Iliad, 2, 56 (repeated in Odyssey, 14, 495, a

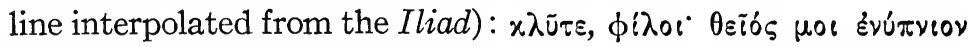

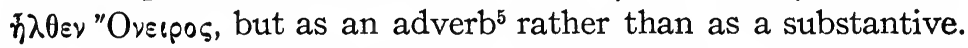
The fifth word, övespos (and its variant, övap), is the regular Homeric term for the general conception of dream.

$$
\text { ILIAD, 2, } 1 \mathrm{ff} \text {. }
$$

The first dream of importance in the earlier work comes in 2, $1 \mathrm{ff}$. Zeus, anxious to do honor to Achilles for the wrong which the latter has suffered at the hands of the ruler of the Greeks, ponders how he may beguile Agamemnon and kill many of the Achaeans; so he plans the sending of a dream. He addresses at once a dream, stationed always near at hand, it would seem from the story, to receive his commands, and bids it deliver his behests to Agamemnon. The dream flies swiftly to the Greek fleet and, likening itself to Nestor, communicates the heaven-sent injunction to Agamemnon, bidding him call

${ }^{3}$ Artemidorus, Onirocritica, 1, 2; Macrobius, Somn. Scip. 1, 3, 2 (ed. Eyssenhardt, Leipzig, 1893); Ioannes Saresberiensis, Polycraticus, 2, 15 (Migne, P. L. 199, 429); Nicephorus Gregoras, Scholia in Synesium De Insomniis (Migne, P. G. 149, 608A); Pseudo-Augustinus, De Spiritu et Anima, 25 (Migne, P. L. 40, 798).

${ }^{4} \mathrm{See}$, for the stemma showing their relation to a common source and to one another, Deubner, 4.

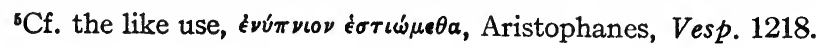


to battle the Greeks to take the Trojan city, for the gods of Olympus are no longer divided in counsel, but will deliver Troy into the hands of the Greeks. / The king, at dawn, assembles the leaders and delivers to them the exact message of the dream. On the strength of this message he announces that he will, after testing the spirit of his warriors, attack and take the city. His oldest counselor, Nestor, also takes for granted that the orders of the dream must be fulfilled. ${ }^{6}$

In this familiar account, note the entire externality, the complete objectivity, of the dream. ${ }^{7}$ The dream is an entity. ${ }^{8}$ There is no statement that Agamemnon dreamed that Nestor appeared, or that he beheld him in sleep. And Zeus, too, accosts the dream as he might accost a person. So strongly is this artistic personification felt that"Oveıpos becomes almost a proper name. The editors, indeed,- Monro and Allen, Christ,

${ }^{6} 2,79-83$. According to these lines the medium through which a dream is reported is of no small consequence. The scholiast of Venetus A (Dindorf, Homeri Ilias, Scholia, 1, 76) declares the whole passage, 76-83, spurious. He was without doubt following Aristarchus. This is of interest. Aristarchus (220-145 B. C.) was a contemporary of Polybius (205123 B. C.) The latter, writing a scientific, rationalistic, pragmatic history, declares that dreams are of natural origin and without divine genesis or prophetic force (cf., e.g., 10, 4-5; 18, 15, 13). The scepticism of the period may have influenced the mind of the scientific textual critic and have suggested his emendation.

${ }^{7}$ The following passages stress the objectivity of the dream in Homer: Iliad, 2,$6 ; 2,8 ; 2,16-17 ; 2,35 ; 2,56 ; 2,59 ; 2,71 ; 23,65 ; 23,68$; $23,97-101 ; 23,106 ;$ Od. 4,$799 ; 4,802 ; 4,838 ; 4,841 ; 6,20 ; 6,41$; 20, 87. Cf. also Hey, 10. The assumption of an 'exoteric' (the term is Hey's) dream for the earlier portions of 'Homer', I am, on the whole, inclined to accept. The lack of agreement, however, on the part of the editors as to just what constitutes the original poems renders assurance about any particular passage well-nigh impossible. See also footnotes 18 and 67.

/ ${ }^{8} \mathrm{Ghosts}$ and the persons of dreams behave alike/ cf. Iliad, 2, 20 and 23, 68; the ghost of Odysseus' mother in Hades is likened 'to a shadow or a dream', Od. 10, 207, for Sleep and Death are twin brothers (see infra, 40), Iliad, 16, 672. Cf. Seymour, 524-525. 
Cauer, Pierron ${ }^{9}$ and others-write it with a capital initial. Of course this does not mean that Homer believed in a God of Dreams. ${ }^{10}$ A11 the later literary references militate against such an interpretation. Nowhere, in the field covered by my investigations, is a dream demanded from a dream divinity or from a king of dreams. ${ }^{11}$ Even in so late a passage as Ovid, Metamorphoses, 11, $585 \mathrm{ff} .{ }^{12}$ it is from Somnus that Iris requests a dream, not from a dream divinity. The Homeric poet here distinctly says that the dream comes from Zeus, ${ }^{13}$ who has the dream daimon at hand to do his bidding. The nearest approach to a dream divinity in the Homeric poems is Hermes. $\mathrm{He}$ shows traces of a connection with sleep and the dream in the Odyssey. ${ }^{14}$ But he is not portrayed as a god of dreams and

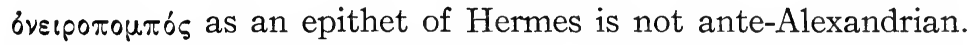
Not before the time of the late Magic Papyri is "Ovespos looked

${ }^{9}$ See their texts: $\quad$ D. B. Monro and T. W. Allen, Homeri Opera (Oxford, 1908); A. Pierron, L'Iliade d'Homère (Paris, 1883). For Christ and Cauer see List of Abbreviations.

${ }^{10}$ Nor does the reference in Pausanias, $2,10,2$, to an $\not \gamma a \lambda \mu a$ 'Ovelpov which stood in the temple of Asklepios in Sicyon, indicate a belief in an actual divinity,"Oveısos. The statue was the sculptor's plastic representation of the poet's conception, without relation to cult. Nägelsbach, Homer. Theol. 182, says: "einen solchen <i.e. Traumgott> kennt überhaupt die griechische Mythologie nicht". Cf. also ibid., 184; Nägelsbach, Nachhom. Theol. 173; Dieterich, 410.

${ }^{11} \mathrm{My}$ collection of dream references goes down into the second century A.D. See Preface, page viii.

${ }^{12}$ See infra, page $43 ;$ n. 185.

${ }^{13}$ Iliad, 1, 63; 2, 1-7.

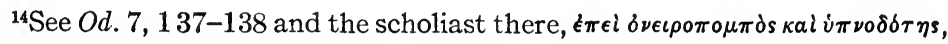
and on 23, 198: Eustathius, 1574, 40; Heliodorus, Aethiopica, 3, 5.

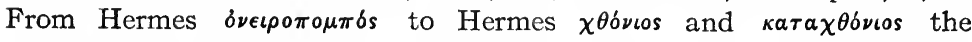
step was short, and then to call upon him in prayer, as upon other chthonic divinities, became natural. Cf. Dieterich, P. M. 802, 5, 8 (see Hey, 38), and the chapter entitled, Hermes als See lenführer, Schlaf- und Traumgott, in Roscher, 66-71. 
upon as a sender of dreams. ${ }^{15}$ We may then deny a god of dreams for this early poem.

But the strongly external origin of the dream is emphasized by the vivid personification which the poet uses here, and this personification the adjective $0^{3} \lambda \circ \varsigma^{16}$ helps. It is found in only five places in the Iliad: twice in our passage $(6 ; 8)$, descriptive of "Ovelpos; twice as an epithet of Ares, 5, 461; 717; and once as an epithet of Achilles, 21, 536. In the Iliad, then, through the connecting link of this adjective, "Ovelpos keeps virile, objective company-the god of war and ti.e Greek hero. Only in the second book of the Iliad is "Ovespos found with any limiting adjectives. These are the above mentioned o ${ }^{3} \lambda_{0 s}(6 ; 8)$, and $\theta \varepsilon \tilde{i o s}^{17}(22 ; 56)$. And so we have "Ovsıos linked with o ${ }^{3} \lambda_{0 \varsigma}$, used elsewhere in this poem of Ares and Achilles only, and with $\theta \varepsilon i 0 s$, 'having its origin from the gods', 'pertaining to the gods', a connotation which, taken in connection with the other factors mentioned, to some degree augments the objectivity of the dream. ${ }^{18}$

${ }^{15}$ Wessely, Griechische Zauberpapyri, 113, $424 \mathrm{ff} .=$ Kenyon, Greek Papyri,

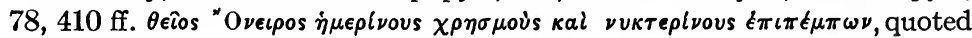
by Hey, 38 .

${ }^{16}$ Connected with $\delta \lambda \circ o s$; $\delta \lambda \lambda v \mu \iota$; see Boisacq and Prellwitz, s. v. Cf. also, L. Meyer, Handbuch der Griechischen Etymologie, 2, 214-215 (Leipzig, 1901).

${ }^{17}$ The meter will not allow $\theta$ tëos in line 22; hence Christ, Leaf, and Fick read ov̂nos, following Nauck (Ber lin, 1877), who adopts the variant reading

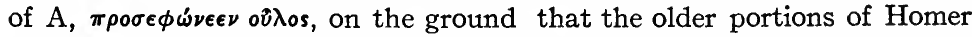

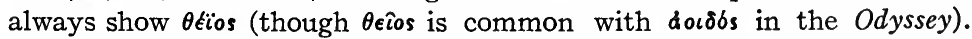
Note in regard to this argument the fact that the dream's voice is spoken of as $\theta e t \eta \dot{t}\rangle \phi \eta^{\prime}$ (41). If o ne could accept the meaning which Dieterich (Archiv für Rel.-Wiss., 9 [1906], 148) finds in this word, 'kraus', 'lockig' (he quotes the collections of passages in Deubner, 12, dealing with the ideal size and beauty of figures which appear in dreams), the objectivity

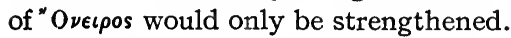

${ }^{18}$ Nowhere in the Odyssey is the personality of the word so strongly

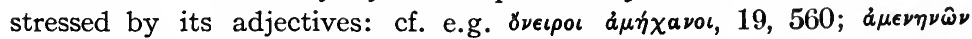
$\delta \nu \epsilon i \rho \omega \nu, 562$. The bearing of the form of dream technique upon the Homeric question is obvious. Compare notes 7 and 67 . 
Zeus sends the dream as he or his consort Hera might send forth Iris, ${ }^{19}$ and the dream acts in many ways as do the gods. ${ }^{20}$ It goes swiftly (17) ${ }^{21}$ to the Achaeans' ships and makes its way to the tent of Agamemnon. It stands above Agamemnon's head $(20 ; 59),{ }^{22}$ taking upon itself the likeness of Nestor $(20-22 ; 58)$, 'most exactly resembling him in appearance and size and form' ${ }^{23}$ The dream then addresses the sleeping chief as the gods address waking men. It declares itself a messenger from Zeus, ${ }^{24}$ warns

${ }^{19}$ Compare the sending of divinities as messengers, Iliad, 24,$143 ; 18,166$. I am not in this paragraph claiming for "Oveipos a divinity and a cult which I have denied him above (page 4), but am merely calling attention to the similarities of action which stress his personality.

${ }^{20}$ Mark the similarities of behavior in the following typical theophanies: Iliad, 3, 121 ff.; 4, 73 ff.; 11, 185 ff.; 15, 157 ff.; 220 ff.; 17, 322 ff.; 18, $166 \mathrm{ff} . ; 24,141 \mathrm{ff}$. Hypnos and Thanatos are also personified: in Iliad, 16, $671 \mathrm{ff}$. , Apollo gives Sarpedon's dead body to the twin brothers, Sleep and Death, to carry to the rich land of wide Lycia. Even more strongly is Hypnos personified in 14, $224 \mathrm{ff}$., where Hera intrigues with him

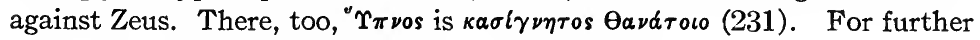
discussion of these personifications see pages $36 \mathrm{ff}$.

L 21 In the primitive belief the dream was no mere mental hallucination, but the persons who seemed to have appeared in the dream were thought to have been actually present. These persons often in the short period of sleep 'came from afar', as did Iphthime to Penelope, Od. 4, 787-841 (infra, 24-28). This necessitated the complementary supposition of great speed; cf. Od. 6, 20./

${ }^{22}$ This position of the ghost and of the person of the dream becomes conventional. The stock phrase, 'stands above the head', 'stands at the head', is common to practically all the dreams of the two early epics; cf. Iliad, 10, 496; 23, 68; Od. 4, 803; 6,21; 20, 32 . See also Euripides, Rhesus, 780; and elsewhere passim. It persists through the middle ages (cf. E. Duemmler, Poetae Latini Aevi Caroli, 2, 267 [Berlin, 1884]: adstans capiti eius, of the vision of Wettin), indeed down into modern literatures (cf. e.g. Milton, Par. Lost, 8, 292: "when suddenly stood at my head a dream"). See infra, 90; n. 68.

${ }^{23}$ In Iliad, 16, 715, Apollo takes on the likeness of Asios, in 17, 322, of Periphas. In Od. 1, 96 ff., Athene appears to Telemachus as Mentes.

${ }^{24} \mathrm{Cf}$. Iliad, 1, 63: 'for the dream too (i.e. as well as other revelations; I take kal with 6rap; see Ameis-Hentze) is of Zeus'. This is important 
Agamemnon not to let forgetfulness possess him on awaking (33-34), and departs in flight (71). In all its acts, then, the dream is objective and personal. It is artistically conceived and portrayed as an external entity, with power of moving, thinking and speaking, like to any herald sent by the gods, a genuine

information. The books on the dream in Greek and Roman cult are too prone to neglect the earlier elements entering into the growth of incubation and to emphasize the elements adopted by the priests of the Olympian deities from the Egyptian cults as something entirely foreign to earlier religious conceptions. The evidence of this line for the early importance of the dream is explicit. Equally inescapable is the inference from the phrase immediately preceding (62-63), in which Achilles links, as of equal prophetic power, the $\mu d \nu \tau \imath s$, who does his soothsaying from divine omens of many kinds, the lepév's, the priest of a definite divinity, who foretells the future from the victims offered by him to his god, and the $\delta$ veiponbios. About the meaning of this last word, there is much dispute. Nägelsbach, Hom. Theol. 172, believes that there is evidence in the two epics that incubation was practiced in the Homeric period. Rohde, 1, 37, is not entirely convinced, but maintains that the $\delta \nu \epsilon \iota 0 \pi \delta \lambda_{0}$ os is not a priest

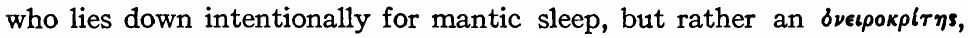
an interpreter of dreams which come unsought, a theory which postulates the recognition by the poet of the allegorical dream (see infra, 33). Hey, 10-11, attacking the problem from another side and denying for the earlier parts of Homer the conception of dream phenomena as psychic, originating within the mind, concludes: "Aus eben diesem Grunde kann $\delta$ veเ Iliad, 1, 63, nicht der Traumdeuter heissen, weil dies die Auffassung der Träume als seeliches Innenbild, den sog. allegorischen Traum, voraussetzen würde. Das Wort bedeutet vielmehr 'Traumseher', zu dem der ovecpos vorzugsweise 'kommt' $V \overline{\pi \in \lambda}$ ". I am on the whole inclined to agree with Hey; but be that as it may, the important fact here is that the dream seer is put on an equal footing, in regard to the clearness of perception with which he may see what is to come, with the two great prophetic priesthoods of the early Greek religion. It is no doubt true, therefore, that belief in the prophetic power of the dream was native to the Greek stock, as it has been found native among all primitive peoples (see Spencer, Tylor, Robertson Smith, Rohde, passim); that the Orient, especially Babylon, the home of magic (Hey, 7), may have reacted upon Greek religion in prehistoric times; but that the dream oracles greatly antedated the historical period (Rohde, 1, 123), as the antiquity of the Amphiaraus oracle at Thebes (Pausanias, 1, 34, 5; Pindar, N. 9, 24 ff.; 10, 8 f.), the Trophonius oracle at Lebadea in Boeotia (Pausanias, 9, 39, 6), the dream 
dream daimon. ${ }^{25}$ No conception could be further from the theories of Aristotle and Freud. ${ }^{26}$

The receiver of the dream is here a man, a convention which is maintained throughout the Iliad. ${ }^{27}$ The conditions inherent in the tale may have determined this, for the personae of the poem are almost entirely male. But whatever factors operated here, there arose later a different convention, first hinted at in the Odyssey, which became practically fixed for tragedythat the dream should come to a woman. ${ }^{28}$ The deity that sends the dream is Zeus, the chief Greek god of the Homeric age.

The dream in Iliad 2 appears at a great crisis of the story, after the provocation of the $\mu \tilde{\eta} \nu$ es of Achilles by Agamemnon. Through the dream the first step toward the atonement for the wrong done to Achilles is taken. Agamemnon is influenced to call a council of the elders and his own folly at this council leads him to propose a plan for testing the Greeks which almost results in the undoing of the expedition. Only the intervention of Hera and Athene (155 ff.) averts an abortive return. The evil done by the king's thoughtless test is, indeed, partially repaired; but the action started by the dream leads to the many oracle of Ge at Delphi, which was displaced by the later Apolline mantic (Euripides, Iph. Taur. 1262; Pausanias, 3, 12, 8; Rohde, 1, 133) seem to indicate; that there was a new influx of incubation influences into Greece from the Orient and Egypt in historic times, but that it merely developed and spread practices which were already known to the Greeks before the historic period. For the kernel of incubation is the belief that the dream comes from heaven.

${ }^{25}$ Cf. Od. 20, 87 ff.; Rohde, 1, 7; Hey, 10.

${ }^{26}$ Their theories would establish the basis of dream activity in memory, in internal psychic processes. In this Aristotle is in remarkable accord with modern thought. Cf. Aristotle, II $\epsilon \rho l^{\prime} \mathrm{E} \nu v \pi \nu l \omega \nu, 459 \mathrm{a}, 8,17,25$; 461a, 14 ff.; 25; Büchsenschütz, 18-20; and Freud, 56 ff. Freud's Literaturverzeichnis, $482-498$, is comprehensive and valuable for a study of the psychology of the dream.

${ }^{27}$ Iliad, 5,$150 ; 10,496 ; 23,62$. Cf: also in the early lyric, Pindar, Pyth. 4, 163, and the dream of Simonides spoken of in Cicero, Div. 1, 27, 56.

${ }^{28}$ Infra, 27. 
battles which the poet of the Iliad details at length, battles in which the death of so many Greeks expiates the contumely that Achilles was forced to endure, brings the latter finally back into the fray, and works the dénouement of the $\mu \tilde{n} v i s$. Yet in all the action which is subsequent to the appearance of the dream each separate incident is directly governed by some deity, or by some chance, or by some present human passion. One does not realize that the dream exerts any influence upon the plot beyond that shown in the immediate moves of Agamemnon. There is no referring back and forth to the mandates of the dream, comparable with what one finds in the Aeneid, ${ }^{29}$ for example, to keep it ever before the mind of the reader as playing an immanent rôle in the plot.

ILIAD, 10, 496-497

A dream reference of much less moment is that in Iliad, 10, 496-497. The content of the vision is not related. Attention is called to it here as containing a few points of artistic interest.

Hector has wrought havoc among the Greeks and has driven them to their ships, far from the city of Troy. So Diomedes chooses Odysseus for a foray, under cover of black night, into the

${ }^{29}$ Compare the frequent references in the other parts of the Aeneid to the dreams found in the following passages and the cross-references in the dreams themselves. The two great protagonists, Carthage and Rome, are brought into conflict through the action induced by dreams: Dido, warned by Sychaeus (Aen. 1, 353-359), flees from Tyre and founds Carthage; Aeneas, on the night of the sacking of Troy, is visited in a dream by Hector $(2,270-297)$; who foretells the doom of Troy and the greatness of Rome. The troubled ghost of Anchises visits Aeneas nightly to hurry him from Carthage $(4,351 \mathrm{ff}$.); the commands of this ghost Aeneas expressly tells his father, in the nekyia of the sixth book $(6,695-$ $696)$, he is obeying. See also $3,147-172 ; 4,554-570 ; 6,695-697 ; 8,26-$ 67. Silius Italicus, who adopts the whole divine machinery for his historical epic, slavishly follows Vergil in this too; cf. 3,$139 ; 4,722-738$; $10,337-386 ; 13,56-62 ; 15,1-151 ; 15,546-559 ; 17,158-169$. Rohde, 1,37 , has pointed out that the souls of departed heroes never encroach upon the guidance of the poetic action in Homer. 
lines of the Trojans, to slay them, or else to discover their secrets. Odysseus urges haste, saying (252-253):

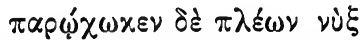

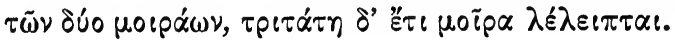

The two, going forth, come upon Dolon, the Trojan, who has left his tent to reconnoiter the position of the Greeks. They kill him, and then continue on their way till they reach the encampment of the Thracians, whom they find sunk in slumber. In the midst of these was Rhesus; beside him were his swift horses tethered with thongs to his chariot. Diomedes rushed upon them, and, after slaying twelve of the king's companions, put Rhesus himself to death: 'And when the son of Tydeus came to the king, him, the thirteenth, he reft of delicious life, as he gasped in his sleep; for an evil dream stood over his head that night, to wit, the son of Oeneus, through the crafty device of Athene' (494-497)..$^{30}$

Here again appears the primitive conception; the dream is external to the sleeper, personal, objective. It takes the position usual to the dream in literature (496); ${ }^{31}$ it disguises itself in

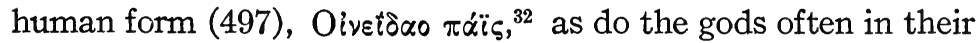

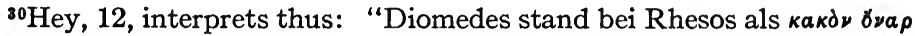

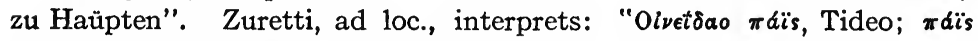
è apposizione di $\gamma_{\nu a \rho}$, è l'argomento, per così dire, del sogno". With this latter interpretation I am inclined to agree, if 497 is genuine. Cf. also Ameis-Hentze, Anhang, on this line. Aristonicus (ed. Friedländer,

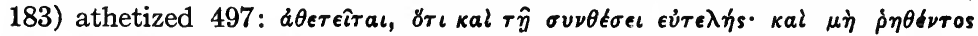

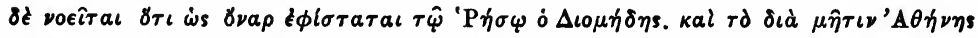

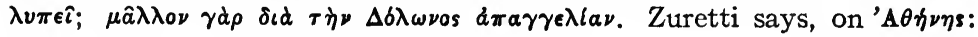
"era crudele; voler l'uccisione e il dolore e la quasi coscienza d'essa, almeno in sogno, è crudeltà raffinata", which seems nearer the meaning of the poet here. Zuretti remarks on $\kappa € \phi a \lambda \hat{\eta} \phi \iota \nu$ : "nella personificazione del sogno esso è immaginato pendere sul capo; in altri tempi l'incubo è creduto sul petto".

${ }^{31}$ Cf. Iliad, 2, 20; 2, 59; supra, 6, n. 22.

${ }^{32}$ Cf. Iliad, 2, 20-22; 2, 58; supra, 6 . 
visits to men. ${ }^{33}$ But it has no determining influence on the further development of the story. It is, however, as before, ${ }^{34}$ introduced at a critical point in the action, namely the entrance of Rhesus. For an oracle had declared that Troy could not be taken if once the horses of the Thracian king had fed upon the grass of the Trojan plain and had drunk the water of the Xanthus. The fulfilment of this oracle is forestalled by the quick action of Diomedes; and the dying Thracian king takes the substance of his dream to the grave with him. Hence it plays no part in the structure of the plot.

The deity who sends the dream is here Athene, not Zeus, as in the other passages of this earlier work; ${ }^{35}$ and the receiver is a male, as is the rule throughout the Iliad. ${ }^{36}$

Another point of interest in this passage is the time at which the dream appeared. This we may deduce from the time at which the Greeks set out upon their reconnoitering. This was during the third watch of the night, according to line $253,{ }^{37}$ or, if, as some maintain, that line is spurious, near dawn, according to line 251 , a line generally considered genuine. Hence the evil dream came after midnight. If, now, the adjective xaxóv in verse 496 means 'foretelling evil fate to him', the time of the dream's appearance is without significance. If on the other hand the

${ }^{33}$ Cf. Iliad, 16, 715; 17, 322; Od. 1, 96; see also footnote 23 .

${ }^{34}$ Supra, 8; infra, n. 200.

${ }^{35}$ In the other passages in the Iliad where a sender is mentioned Zeus is the responsible divinity: 1,$63 ; 2,1 \mathrm{ff}$. (supra, 6). Athene's activity here is an anticipation of her activity in dream sending in the Odyssey: cf. infra, 24; 51 .

${ }^{36}$ The ivelpor6 6 os of 1, 63; Agamemnon, in 2, 1-47; Achilles, in 23,62107; Rhesus, in 10, 496. Infra, 27.

${ }^{37}$ This line was rejected as spurious by the Alexandrian trio, Zenodotus, Aristophanes, Aristarchus. Fick, in his comments on 252-253, rejects both lines, partly on linguistic and syntactical grounds, partly on the authority of the above-named trio. Leaf, La Roche and others, however, retain line 253 and suggest numerous explanations of the syntax and interpretation. See their notes ad loc. 
adjective means rather 'deceptive', 'untrue', then the hour becomes important, for elsewhere'all the Greek and Roman poets place deceitful dreams before midnight. ${ }^{38 /}$ Homer's introduction of a deceitful dream just before dawn would then indicate that the opposing folk-belief and artistic convention were later in origin than the early epic. ${ }^{39}$ But this is pure conjecture; with a restraint which he does not always feel necessary the poet has refused the knowledge of Rhesus' inmost thoughts and the content of the dream is not given. And without that content one cannot control the meaning of the adjective xaxóv or determine during what portion of the night Homer would have thought of deceitful dreams as sent by the gods.

\section{ILIAD, 23, 62-107}

Another example of the objective dream in the Iliad is the appearance of Patroclus to Achilles, in Book 23. This is the starting point in European literature for the apparition of the dead

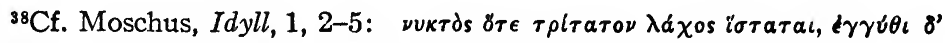

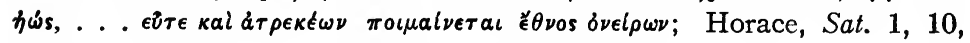
33: post mediam noctem visus, cum somnia vera; Ovid, Her. 18, 195-196: Namque sub aurora, iam dormitante lucerna, Somnia quo cerni tempore vera solent; Tertullian, De An. 48; Philostratus, Apollonius of Tyana, 2, 37. Vergil, Aen. 6, 898, indicates the time of Aeneas' exit from the lower world by dismissing him through the gate of false dreams, i.e. before midnight (this explanation of the Vergilian passage was suggested by W. Everett, Class. Review, 14, $153 \mathrm{ff}$. It has been accepted by C. Knapp, Vergil's Aeneid [Chicago, 1901], by T. E. Page, Aeneid ${ }^{2}$ [London, 1902], and by Norden in his exhaustive commentary on Aeneid 6) (Seasons also affected the reliability of dreams: autumn dreams were generally considered deceitful, spring dreams most probable of fulfilment:/ cf. Tertullian, loc. laud.: Ex temporibus autem anni verno magis quieta, quod aestas dissolvit animas et hiems quodammodo obduret, et autumnus tentator alias valetudinem succis pomorum vinosissimis diluat; Alciphron, Ep. 2, 2 (ed. Schepers, Leipzig, 1905); Plutarch, Quaest. Conv. 8, 734D; Büchsenschütz, 37-38; Granger, 32.

${ }^{39} \mathrm{Cf}$. the note on Horace, Sat. 1, 10,31-35, in Kiessling-Heinze ${ }^{4}$ and the standard editions on the other passages in the preceding note. 
in dreams. ${ }^{40}$ The ghost appeared when deep (vंjounos, 63) sleep had laid hold upon Achilles. ${ }^{41}$ The specter of Patroclus, $\psi u \times \dot{n}$, is

${ }^{40}$ The influence of dream experiences upon the belief in immortality and the conceptions of the other world is of great importance and generally recognized. The body of the sleeper lay, in the eyes of his friends, unmoved; but, on awaking, the sleeper told of the journeys he had made and the marvels he had seen. From this primitive man postulated a second self or soul, or a plurality of souls. The things which the sleeping soul had seen were no less real than the sights which met the eyes of the waking self, only different. Or else objects appeared before the sleeper or a companion returned to him from the house of the dead to tell him what his experiences had been and where he was. From this primitive man assumed a Hades or an Elysium. The sights reported by the returning soul of the ghost and the places visited by the wandering soul of the dreamer became merged, and from this merging grew the picture of the other world. Now the elements for that picture came from the mind of the sleeper and so, as his waking life increased in complexity, his picture of Hades kept pace with it. The trance and the ecstasy were physical conditions the experiences of which strengthened this belief. It is an antiquated anthropology which traces all of the elements of these conceptions back to dream experiences, but no school denies to dream experiences the great and influential part they played. Plato's sublime myth of immortality, the vision of $\operatorname{Er}$ (Res Publica, 614b), evolves the picture of the future life from the experiences of the trance, as does Plutarch's vision of Thespesius (De Sera Num.Vind.22); Cicero's Somnium Scipionis evolves it from the dream. The nekyia once established drew features from all sides and was told in many settings. For example, in the Culex, 202-384, the spirit of the murdered gnat appears to its murderer in a dream and gives him a description of Hades. For further theory or comment see de Félice, 119 ff.; Gomperz, 1, 18 ff.; 25; 32; 33; Dieterich, Nekyia (passim); Spencer, 1, 147 ff.; 3, 7 ff.; 3, 22 ff.; Rohde, 2, 392-393; V. G. Ettig, Acheruntica (cited by de Félice), 360. See, also, n. 102.

${ }^{41}$ The passage has been accepted by Fick, 202, but rejected by many others. The crux lies in the occurrence here of a conception which is in direct opposition to the views stated elsewhere in the Iliad, and also in the Odyssey (with the exception of the Elpenor episode, Od. 11, 51 ff.), the conception that the souls of the dead must await burial before entering Hades. In all other portions of the poems the belief holds that the soul enters Hades immediately on leaving the body, without the fulfilment of any previous condition. The idea involved in the opposite belief rested on the assumption that it was necessary entirely to burn the body so that 
the counterpart of the living Patroclus in stature, fair eyes, and voice. ${ }^{42}$ Though a $\psi u \times \dot{\eta}$ (65), it has a body (67); it stands above Achilles' head (68), as each of the dream forms discussed above stood over the head of him to whom it had been sent $(2,20 ; 2,59$; $10,496) ; 4$ it cannot enter the gates of Hades, for the other souls keep it afar off (72); $;^{44}$ these souls are $\varepsilon(\delta \omega \lambda \alpha \kappa \alpha \mu \delta \nu \tau \omega \nu(72)$, phantoms, illusive images of dead men; by the action of these phantoms Patroclus is not allowed to cross the river (73); $; 5$ the ghost asks for Achilles' hand. This is not the customary gesture at parting, but the soul desires, in view of their separa-

the soul freed from it could come to rest. On the ground of this difference Lange, Nitzsch, Kammer reject the lines which contain the conflicting conception and Kiene considers the whole narrative of the appearance of the ghost of Patroclus foreign to the original Iliad. (For the views of these critics, see the Einleitung to Book 23 in the Anhang of Ameis-Hentze).

${ }^{42}$ The ghosts of the dead, whether seen in the lower world or appearing in dreams, retain the marks of the wounds by which they came to their death or the traces of the funeral fires by which their bodies were destroyed. This idea is naive and universal. It is said that the Chinese mutilate their criminals so that their spirits may forever carry their disgraceful wounds. Professor K. F. Smith's fine note on Tibullus, 1, 10, 37-38 (in his edition of Tibullus, New York, 1913), discusses this primitive belief. The idea recurs in the Oresteia fragment of Stesichorus (fr. 42, ed. Bergk), where Agamemnon appears in a dream in the form of a serpent bearing on its head wounds from Clytaemestra's ax. Vergil repeats it in his description of Hector, Aen. 2, 270-297. See also, 6, 450; 498. The elegists, perhaps under Alexandrian influence, carried further the identification of corpse or ashes and surviving wraith: Tibullus, 3,2 ; Propertius, $1,19,18 ; 2,13,32 ; 58 ; 3,5,30 ; 4,5,4 ; 4,7,12 ; 94 ; 4,11,3 ; 8 ; 20$; 58; Ovid, Met. 10, 49; 11, 691; Persius, 1, 38; Silius Italicus, 12, 457. See also Hardie, 94-95.

${ }^{43}$ Supra, $6 ; 10$.

${ }^{44}$ The demand of the weary soul, that would enter Hades, for burial is paralleled in the early literature by the dream of Pelias in regard to Phrixus, Pindar, Pyth. 4, 163 (infra, 66). See also, for a similar conception, Euripides, Hec. 30 (infra, 85). This idea appears innumerable times in the later literature.

${ }^{45}$ Always the Styx in the Iliad; in Odyssey, 10, 513, Acheron is mentioned. 
tion forever, to give by this unusual form of leave-taking a more powerful expression to their feeling of nearness. ${ }^{46}$ In making this request the soul wishes something incompatible with its nature (99 ff.); it cannot return from Hades after it has been given to the fire $(75-76)$. The soul has a wider vision than Patroclus had possessed in life; it knows now that bitter fate surrounded it even from birth (78-79); it prophesies that Achilles, too, is doomed to die beneath the walls of Troy $(80-81) .^{47}$ One last request it makes, that its bones shall not be buried apart from those of Achilles (83), but that a common cinerary urn (91) shall contain their ashes, that in death they may lie together even as in life they had been reared together. Achilles thereupon asks the spirit why it has come to him with such commands (94-95), promises to execute its every injunction (95-96), and finally entreats Patroclus' spirit to stand nearer so that they may embrace each other and share their grief in common (97-98). Upon stretching out his arms to seize the spirit of his friend, Achilles failed in his attempt, ${ }^{48}$

${ }^{46}$ Cynthia's ghost, Propertius, $4,7,94$, will rub bone on bone, mixtis ossibus ossa teram.

${ }^{47} \mathrm{Such}$ prophetic power shows itself in dying heroes. In Iliad, 22, 356360 , Hector, at the point of death, foretells to the exulting Achilles that the latter will die at the hands of Paris and Phoebus Apollo, a more definite prophecy than that here uttered by the returning wraith of Patroclus. The wraith had shown this prophetic power, also, when at the point of death he foretold to his foe, Hector, that he would fall at the hands of Achilles: see Iliad, 16, 851 ff. Cf. Cicero, Div. 1, 30, 62-65; Diodorus Siculus, 18, 1 (ed. Fischer, Leipzig, 1896).

${ }^{48}$ Lines $93-98$ are rejected by Kammer, 505 f., as a later interpolation. But this view has not found acceptance; for, if $93-98$ be eliminated, then it is the spirit of Patroclus which stretches out its hands, not Achilles, and $\psi v \chi \eta^{\prime}(100)$ would be the subject of $\dot{\omega} \rho \epsilon \xi a \tau o$ (99) and $\ddot{\varphi} \chi \epsilon \tau o$. But it is only by stretching out his arms that Achilles can make the discovery which he records in line 104 . It is the effort to clasp the spirit which wakes him. A similar physical effort arouses the charioteer in the Rhesus, 780-788; infra, 97. 
for the soul, like smoke, departed beneath the earth, gibbering

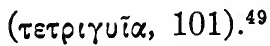

So powerfully does the vision affect Achilles that he is stirred from slumber (101) and cries out in the famous lines, so important for a correct understanding of the Homeric theory of the nature of the soul after death if they were not so baffling to positive exegesis (103-104):

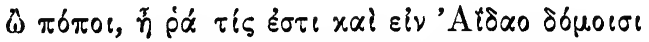

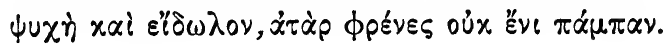

The three words which cause the difficulty are $\psi u x \eta^{\prime}, \varepsilon^{\prime \prime} \delta \omega \lambda$ ov, and фpéves. Hardly two scholars can be found in agreement concerning the meaning of any of them. ${ }^{50}$ The common sense

${ }^{49}$ This word is used of the cracking of the backs of wrestlers, Iliad, 23, 714. Elsewhere in the early epic it is confined to the sounds uttered by birds: in Iliad, 2, 314, it is the noise made by the young of the sparrow. Ameis-Hentze, Anhang, take the word to mean in Iliad, 23, 101, "zirpend", remarking: "denn auch die Stimme der Psyche ist nur ein schwaches Abbild der Stimme des Lebenden". This, however, is probably not the meaning. In Od. $24,1-10$, souls are likened to bats in action and utterance; $\tau \rho l \zeta \omega$ is there used of both bats and souls. Vergil, Aen.6, 282-284, pictures dreams clinging (batlike) beneath every leaf of an elm in the entrance to Hades. Cf. also, Euripides, Hec. 70-71; Silius Italicus, 13, 595-600. This likening of souls, dreams, and kindred conceptions to birds is an ancient bit of folk-lore. Homer, in using $\tau \epsilon \tau \rho \iota \gamma v \hat{\imath} a$, was writing under the influence of that conception. See below, note 184, for bibliography. Add Granger, 42; and 44: "There was an old belief that dreams became false at the fall of the leaf".

${ }^{50}$ The materials for a reconstruction of the Homeric view of life after death and the nature of the soul are the accounts of the funcrals of Patroclus and of Hector, Iliad 23 and 24 respectively, the two nekyiae in the Odyssey, 11 and 24, and smaller references throughout. Rohde has distinguished sharply two conceptions of the departed soul, which he designates as the ghost faith and the shade faith, and these demand, he declares, a radically different treatment of the corse. The former conception is that the soul can return to its old home and haunt the living. It is capable of doing immense and unearthly injury; it is a ghost which must be placated by offerings of clothing and food and all the things the living man had needed. Mummification was practiced to preserve for the ghost its old 
interpretation, however, seems to be that $\psi \cup \times \eta \dot{n}$ is adequately represented here by 'soul'. It, among the Greeks, as among all primitive peoples, escapes out of the mouth of the dying or the wound of the mortally wounded.51 With the rise of Pytha-

abode to which it might return. Ancestor worship was naturally conjoined with such a belief. The 'shade faith' was based on entirely different premises, to wit, that the spirit can be absolutely banished from earth and shut up in Hades, whence it cannot return to help or to harm the living. Starting from this conception, relatives burned the body to cut the spirit off all the more from communication with the living. When the body was once reduced to ashes, the soul no longer constituted a menace. As a resultant there was no offering of gifts to the dead and no form of ancestor worship. The first of these beliefs is primitive and unreflecting; as including ancestor worship, it is the most extensively held of all faiths (cf. e.g. W. Crooke, Popular Religion and Folk-Lore of Northern India, 1, 175 [London, 1896]). The part the dream has played in developing such a faith Spencer has demonstrated and exaggerated (see his indices). The second is the belief of a more advanced peoplethe product of intellectual growth and reflection. These beliefs exist nowhere pure, and least of all in Greece during any period which can be controlled by literary evidence. In the epic the predominant belief, however, was the shade faith; for this period there is little evidence for the cult of ancestors, or for a belief in the power of the dead to return and work vague but terrible injury. To the shade faith belongs the account of the funeral of Hector, Iliad, 24, 718-804, completely. But such consistency is not universal and there are numerous traces of the survival of the older ghost belief. To it the description of the funeral of Patroclus does not entirely belong, nor is this description a conscious reconciliation of the older and the newer conceptions, as Lang (82-107) cleverly maintains by assigning a short period during which the soul can return to earth before it is finally confined to Hades-a period for giving gifts to the dead, a period, however, to be made as brief as possible for the sake of the dead itself. Rather is it a cento of elements from both conceptions. The burning on the pyre belongs to the later shade belief; the sacrifice of horses, cattle, hunting dogs, Trojan captives, the offerings of two-handled jars of honey and oil $(23,166-177)$, the promise of Achilles that he will give to Patroclus a share of the ransom for the dead body of Hector $(24,592-595)$, are all survivals of the ghost belief. A knowledge of these conflicting elements is necessary for an understanding of the account of the Patroclus dream.

${ }^{51}$ Examples of this are found in Iliad, 9, 409; 14, 319; 16, 505. 
goreanism it was considered the real self, the personality, which entered into each incarnation..$^{52}$

The $\varepsilon$ ' $\delta \omega \lambda_{\circ} \nu$, 'wraith', is the part which endures when the body disintegrates; it is, so to say, the Platonic 'idea' of the dead person. It is similar to the wraith of Helen which Stesichorus ${ }^{53}$ pictured, in his recantation, to explain the Trojan war; similar to the phantom of Helen in Euripides' Helena ${ }^{54}$ which went to Troy with Paris; similar to the ghost ( $\varepsilon^{\prime}(\delta \omega \lambda \circ \nu)$ of the mighty Heracles, which Odysseus met in Hades while the real soul of the hero was away banqueting with the immortal gods ${ }^{55}$ similar to the phantom, fashioned in the likeness of Iphthime, which Athene sent to the anxious Penelope. ${ }^{56}$ It is the same as the facies of Anchises which appears to Aeneas in the fifth book of the Aeneid, ${ }^{57}$ for this facies is not the in spite of the fact that the poet, a few lines further on, ${ }^{58}$ makes

${ }^{52}$ W. R. Hardie (The Classical Quarterly, 193-195), in a discussion of the dream in the proem to Ennius' Annales, 1, i, v and xi (Vahlen), where Homer appears to the Roman poet, assumes that it can only be a wraith of Homer, an $\epsilon^{\prime} \delta \omega \lambda o \nu$, which thus appears; that the real self, the $\psi v \chi \gamma$, went, according to Ennius' Pythagorean tenets, into each of the successive

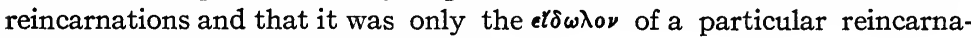
tion that could appear to the dreamer.

${ }^{63} \mathrm{I}$ refer to the fragment from the Helena palinode, Bergk, 26. The story of the $e^{t} \delta \omega \lambda$ ov of Helen rested upon the conflicting legends in regard to her adventures after she had been carried away from the home of Menelaus. One legend, the Homeric story, took her to Troy; another, of like currency, took her to Egypt. Herodotus, 2, 112-120, tells the Egyptian version at considerable length and discusses Homer's reason for choosing the Trojan legend. That Stesichorus made use of the legend of the wraith is a conjecture of Hardie's (see n. 52).

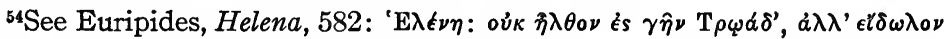
in. Especially pertinent are 608-615, where the messenger reports how the $\epsilon \iota \delta \omega \lambda o \nu$ escaped them and went to heaven, announcing that Helen was guiltless and had never gone to Troy.

${ }^{55} \mathrm{Od} .11,602$.

${ }^{56} \mathrm{Od}$. 4, $795 \mathrm{ff}$. Compare below, 24-28.

${ }^{67}$ Vergil, Aen. 5, 722-723.

${ }^{58}$ Aeneid, $5,731$. 
the phantom speak as if it were the anima. It is the $\varepsilon^{\prime}(\delta \omega \lambda \circ \nu$, since it comes down from Heaven (caelo . . . delapsa, 722), whereas the Vergilian Elysium is consistently represented as subterranean. It is an $\varepsilon i \delta \omega \lambda \circ \nu$ by which Juno lures Turnus from battle. ${ }^{59}$ It is the $\varepsilon i \delta \omega \lambda \circ \nu$, says Pindar, which alone remains throughout all time. ${ }^{60}$

In regard to $\phi p \varepsilon \dot{v} \varepsilon \varsigma$ the strife among scholars has been between the meaning 'Lebenskraft' (Ameis-Hentze) ${ }^{61}$ and the meaning

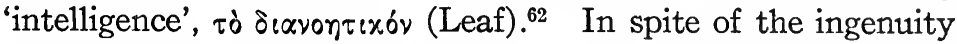
of the critics oúx हैvı $\pi \dot{\alpha} \mu \pi \alpha \nu$ seems to me to exclude the latter interpretation. The ghost does give evidence of possessing memory, perception, thought, if not omniscience; what it lacks is shown to Achilles by his inability to grasp it. The corporeal substance together with the life principle inherent therein has left the ghost.

And so this dream apparition has a $\psi v \times \dot{\eta}$, an airy soul, and a shadowy wraith, or $\varepsilon l \delta \omega \lambda \circ v$, but it is unsubstantial and there is no life-giving principle in it. Its intelligence, if in some respects greater than that of the living person, is not all-knowing: it has not the full report of what has been happening on earth; the ghost of Patroclus is quite unaware of the grief Achilles has suffered and of the preparations which he has made fittingly to celebrate the funeral of his comrade. This, then, is the artistic

${ }^{59}$ Aeneid, 10, 636 ff. See Hardie (cited in note 52), 188-195, for a more detailed discussion of some of these passages.

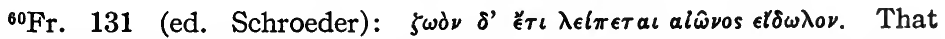
the distinction between $\psi v \chi \eta$ and $\epsilon \ell \delta \omega \lambda o \nu$ was not always clearly drawn is shown by the words with which Plutarch (Consol. ad Apoll. 35, 120)

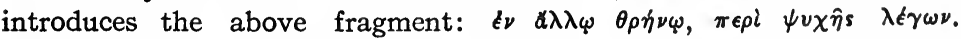
Kammer, $516 \mathrm{f}$., decides that the common belief assumed no life, not even dream life, after death, and so sees in this dream-vision of Achilles a marked advance on the theory prevalent in the poet's day.

61Anhang: "im Gegensatz zur luftigen $\psi v x \eta$ und zum schattenhaften et $\delta \omega \lambda o \nu$ das $Z$ werchfell als feste Substanz und Hauptträger des physischen, wie des geistigen Lebens gedacht".

${ }^{822}, 621$. 
theory that lies behind the picture which the poet draws of the dream ghost.

No deity sends this ghost. ${ }^{63}$ The dream comes of its own volition. The cause which brings it is a personal one, a desire of the restless spirit to enter the gates of Hades and be at peace (71). Perhaps this explains why this dream plays so small a part in advancing the plot. The machinery of the action of the Iliad is frankly controlled from Olympus. Whatever does not emanate from that source may create a powerful episode or adorn an attractive incident, but it does not play a large rôle in shaping the outlines of the story. But, though the dream under consideration does not affect the economy of the poem, it is, considered by itself, a truly Homeric dream of the early, objective, naive kind. The description of Achilles, as he awakes and cries aloud, impresses us with this external and objective origin of the dream.

ILIAD, 22, 199-200

Of far different type is the dream conception in Iliad, 22, 199-200:

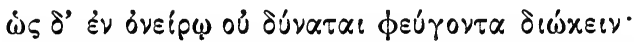

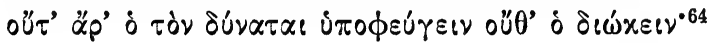

${ }^{63}$ Seldom is a deity mentioned as sender of the vision when the dead appear in dreams. One is often left to infer that the dead themselves are responsible for the dream-visitation; cf., for this early period, Darius in Aeschylus, Pers. $176 \mathrm{ff}$. (infra, $60 \mathrm{ff}$.); Agamemnon in the Choeph. $526 \mathrm{ff}$. (infra, $70 \mathrm{ff}$. ) and also in the Oresteia fragment of Stesichorus (infra, 73; quoted below, 82), Bergk, 42; Clytaemestra in the Eumen. 94 ff. (infra, 74 ff.); Phryxus in Pindar, Pyth. 4, 163 ff.; Agamemnon in the Electra of Sophocles, 417-425 (infra, 79 ff.); Polydorus in Euripides, Hec. 1-58; the dead unknown, to Simonides in the story told by Cicero, $D i v$. $1,27,56$. The instances in the later period, for both Greek and Latin literature, are innumerable. The Aeneid will illustrate for the Roman epic: Sychaeus in 1, 353; Hector in 2, 270-297; Dido's threat, 4, 384; Anchises in 4, 351; 5, 721-740; 6, 695-697.

${ }^{64}$ Compare the similar conception in Aen. 12, 908-914, evidently copied from this and expanded. 
We have here a dream reference which is very modern in its tone and in the phenomenon which it notices. It is the description of a dream state. That is to say, the dream in this passage has lost all personality; there is no dream phantom or dream daimon. The vision-experience exists only in the mind of the sleeper. Achilles is pursuing Hector under the walls of Troy and his inability to overtake him is likened by the poet to the attempted pursuits and escapes of our dreams. Into the psychological and philosophical conception upon which this phenomenon is based I have no intention, at this time, of going ${ }^{65}$ But from an artis-

${ }^{65}$ For the study the science and philosophy of the dream and its use in cult one may compare, on the Greek side, the following monographs: B. Büchsenschütz (94 pages); F. O. Hey (40 pages); F. O. Hey, Religion (60 pages). The short treatise by Büchsenschütz is to a certain extent antiquated; it antedates the vast amount of work that has been done in Greek philosophy, and especially on the philosophic fragments, during the last fifty years. Nevertheless it was based on a fresh examination of the sources which he had before him and his work is still to be superseded. He traces the history of the scientific theory of the dream down through the Ionic and Eleatic schools; Pythagoras, Democritus, Socrates, Xenophon, Plato, Aristotle and the Peripatetics, the Epicureans, the Stoics, early and late, the physicians (Galen, etc.). He then turns to the books containing collections of dreams and their interpretations, concluding with a résumé of Artemidorus' Onirocritica. Hey's two short monographs were written later; consequently he could take advantage of the vast strides which had been made in the study of anthropology and comparative religion. In the first programm he studies the dream from the standpoint of cult and religion as found (1) in the Homeric period, (2) on the Greek mainland in the early classical period, in which there was interaction of oriental and native elements, and (3) in incubation and dream interpretation in its relation to medicine. In the second programm. he traces the influence of the dream and dream experiences in fashioning the religious conceptions of the Greeks. He shows, however, a Spencerian overfondness for the dream in attributing to it a much greater influence in the realm of religious ideas than recent scholars are willing to grant. Furthermore, he is not always judicious in the distinctions which he draws between the conceptions which any given author accepts for artistic purposes and the scientific explanation of dream phenomena which that same author may hold. Literary convention often causes the former to limp behind the latter. There are accessible no corresponding mono- 
tic standpoint, certainly, it is unlike the other dream pictures of this earlier work, which are so clearly external, originating from without the sleeper. If, as Aristonicus, Leaf, Fick, Bekker, and Düntzer ${ }^{66}$ maintain, these lines are a later addition, we find in them exactly what we might expect, to wit, a development from the more primitive and lively conception of the personality of the dream, such as we see in Iliad 2, to the belief, belonging to a later, more reflective period, in a psychological dream state. ${ }^{67}$

graphs on the dream in Latin literature. In Harvard Studies in Classical Philology, 24, 163-164, there is a summary of an unpublished Harvard dissertation by S. H. Newhall, Quid De Somniis Censuerint Quoque Modo Eis Usi Sint Antiqui Quaeritur. It is to be hoped that this dissertation, containing valuable epigraphical material, a "complete collection of dream inscriptions and dedications" (ibid. 163), may before long be made more accessible (see the indicated volume of Harvard Studies for an outline of Dr. Newhall's investigation). On the narrower side of incubation, there are two fair-sized treatises: L. Deubner, De Incubatione Capitula Quattuor (Leipzig, 1901), a painstaking, careful study. Its contents are indicated by the chapter headings: (1) De Somniis Divinis, (2) De Incubandi Ritibus Symbolisque, (3) De Carmine Delphico Euripideo, (4) De Incubatione Christiana. The second treatise is that by Mary Hamilton, Incubation or the Cure of Disease in Pagan Temples and Christian Churches (London, 1906). Pp. 223. The treatment is popular and the scope of the work is correctly indicated by the subtitle. The ground is covered with intelligence, but without originality, and the citation of authorities and sources is totally unsatisfactory. Henri Lechat in Daremberg-Saglio, Incubatio, can also be consulted with profit. In addition to these special treatises there is much to be gleaned, from general works in a larger field, on what may be called the non-artistic aspects of the dream, Greek and Roman. Of particular value are the following: Bouché-Leclercq, 2, 251; $260 ; 269 ; 301 ; 3,76-77 ; 275 ; 310 ; 380-381$; Campbell, 144; 180; 227; 231; 368; De Marchi, 1, 37; 238; 239; 240; 285-289; Dill, 445; 448-469; Dyer, 235-248; Gilbert, 251-252; Gomperz, 1, 18 ff.; Gomperz, Essays, 72-79; Granger, 28; 31-33; 35-37; 42; 44; 46; 48; Hardie, Lectures, 71-84; 91; 94-95; Maury, Magie, 229-255; Maury, Histoire des religions, 2,447 ff.; Rohde, 1,$5 ; 37 ; 113-125 ; 131-134 ; 184 ; 186$; $189 ; 2,57-58 ; 392-393$.

${ }^{66}$ See the List of Abbreviations for the full titles of these works. The comments to which I refer will be found in notes on lines 199-200.

${ }^{67} \mathrm{This}$ observation hints at the possible bearing of the artistic form in which the dream is found upon the question whether a given passage 
These, then, are the dream references in the Iliad of significance for a study of the use of the dream as a literary device. ${ }^{68}$

belongs to the original 'Homer'. Personally I believe that these verses are late. For, however much the more primitive conception may appear in later literature as an artistic convention or affectation, it is certain that the belief in a psychological dream-state could not have been found in the earliest form of the Homeric epic. See also notes 7 and 18.

68In 24, 682 ff., Hermes appears to Priam while the latter is slumbering and 'stands above his head' (682), an echo of the formula used of the dream (cf. $\mathrm{n}$. 22). The boundary line between dreams and visions is nowhere drawn with that definiteness which would make dogmatic statement possible. But I consider this a waking vision, not a true dream. Hermes' coming seems to wake Priam, for in the lines which follow (689-691), Hermes is there in physical presence before their waking eyes to yoke the mules and drive them through the camp. This then is a waking visitation of the god. I have excluded such from comment in accord with the aim of this study. Cf. n. 22 . 


\section{THE ODYSSEY}

In the later poem, the Odyssey, the treatment of the dream in some respects follows the same lines as in the Iliad. In other respects, however, there are evident advances. The longer passages to be taken into consideration are $4,787-841 ; 6,13-51$; 19, 509-581. Of less import are 20,61-90, and the still shorter references, $11,207,222 ; 14,495 ;{ }^{69} 19,581 ; 21,79 ; 7024,12$.

\section{Odyssey, 4, 787-841}

The first dream described in the Odyssey appears to Penelope ${ }^{71}$ after the departure of Telemachus to consult with Nestor. Athene fashioned a phantom, in form like Iphthime, sister of Penelope, and sent it to cheer the wife of Odysseus. The phantom of Iphthime, entering the chamber, carries on a long dialogue with the sleeping queen. It bids her to be of good courage in regard to her absent son, but refuses to tell her aught of Odysseus.

In some features this dream is identical in character with the naive dreams of the Iliad..$^{72}$ It comes from without the dreamer; it is objective and personal, sent by a divinity. But there are differences in detail, with obvious changes, additions, improvements, refinements, showing a more mature art, and conscious reflection. Here the sender is the gleaming-eyed Athene ${ }^{73}$ (795), who takes upon herself in the Odyssey the dramatic function performed in the Iliad by Zeus. For as Zeus is the active divinity in the Iliad, so Pallas Athene is the chief agent in the

${ }^{69}$ This line, 14, 495 (cf. supra, 2), has, from the time of Aristarchus on, generally been regarded as an interpolation from Iliad, 2, 56 .

7021, 79 is identical with line 19, 581 .

${ }^{71}$ Od. 4, 787-841.

${ }^{72}$ Compare with Iliad, 2, 1-47; 10, 496-497; 23, 62-107 (supra, 2-20).

${ }^{73}$ In one passage in the Iliad, 10, 496-497, she is the responsible divinity who sends the evil dream (supra, 11, n. 35). 
restoration of the hero of the Odyssey. That which is sent is a phantom $\left(\varepsilon^{\prime} \delta \omega \lambda\right.$ ov, 796), which the goddess had fashioned in the likeness of Penelope's sister, as in Iliad, 2, $1 \mathrm{ff}$. the dream had taken upon itself the form of Nestor. ${ }^{74}$ This phantom, Iphthime, is sent from afar $(798 ; 811)$; she comes in the dead of night (841) $;^{75}$ her entrance and her exit are minutely described; she enters by the strap of the bolt (802), and leaves by the bolt that fitted into the doorpost (838) $;{ }^{76}$ she 'stands above the head' $(803)^{77}$ of Penelope as she 'sweetly slumbered at the gates of dreams' (809). Like the baneful dream of Iliad 2, the phantom names the divinity who sent her (828-829). She comes to impart one bit of encouragement and refuses to divulge anything else, in spite of Penelope's requests: $\gamma \alpha \times \delta \nu \delta^{\prime} \alpha \dot{\alpha} \varepsilon \dot{\mu} \omega \lambda_{\imath} \alpha$

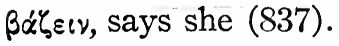

The dream, as in the earlier work, appears at a time of crisis, ${ }^{78}$ at one of the dramatic turning-points of the poem, the departure of Telemachus to visit Menelaus, the so-called secondary plot of the action of this epic. Its influence upon the economy of the narrative is implied rather than openly or definitely stated by the poet. Penelope had despaired of the life of her son, exposed as he was to the wrath of the suitors, and had become fainthearted about the return of Odysseus. Though the $\varepsilon(\delta \omega \lambda$ ov refuses to tell Penelope whether Odysseus is alive or dead (831-837), its words of comfort about the journey of Telemachus suggest an affirmative answer to the queen's query. The strengthening of this hope fortifies her resolution to

${ }^{74} \mathrm{The}$ fact that this passage is an imitation of Iliad, 2, $1 \mathrm{ff}$., Hey, 12, has demonstrated (supra, 2).

${ }^{75} \mathrm{I}$ follow the usual interpretation, which explains $a \mu 0 \lambda \gamma b s$ as an old word for $a \kappa \mu \eta \eta$.

${ }^{76} \mathrm{This}$ description is drawn with 'Homeric' simplicity and attention to detail. It shows, however. an amount of detail which is foreign to any description of a dream in the earlier work.

${ }^{77} \mathrm{Cf}$. Iliad, 2, 20; 59 (supra, 6); 10, 496 (supra, 10); 23, 68 (supra, 14); and supra, n. 22.

${ }^{78}$ Cf. Iliad, 2, 1-47; 10, 496-497; 23, 62-107. See supra, 8, 11, 20. 
await further her wandering hero's return and to withstand the importunities of the suitors. The continued opposition of the queen to their assaults upon her fidelity is necessary to the story. Courage in resistance, while not visibly affecting the plot, is none the less essential to its being. This courage the dream secures; for that it is important to the economy of the poem. Such a method of motivation is less direct than that of the dream in the second book of the Iliad and less direct than much that is found later. ${ }^{79}$ But in proportion to its lack of directness it gains in artistic refinement. It shows a technique that indicates familiarity with the medium in which the poet is working and a correspondingly increased skill in execution. It indicates a sophistication such as one might expect in a later poem.

The structure of this dream when compared with that of the dreams of the earlier work is seen to be very complex. It is what we may call a dialogue dream. The germ of this type of dream is found in Iliad, 23, 62-107;/ the ghost of Patroclus speaks once and Achilles replies once before it vanishes. But in the passage in the Odyssey the poet has accepted this model and has expanded it into a dialogue of considerable proportions, in which the phantom speaks three times and Penelope twice addresses it in turn and questions it. This expansion into a longer dialogue inevitably introduces further refinements in technique. In Iliad 2, for example, Zeus gave to the baleful dream a definite message for it to deliver in the exact words of the sender (10):

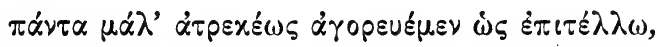

says he. A comparison of the words which the dream spoke (28-32) with the phrases of the original injunction (11-15)

${ }^{79}$ There is later, in many cases, an assumption of simplicity which is just as artistic and quite as artificial as a natural sophistication. For more direct motivation in later works of the classical period, see my discussions of Aeschylus, Pers. (infra, 60-66), Prom. Vinc. (infra, 66-70), Eumenides (infra, 74-77), Euripides, Hec. (infra, 85-90), Iph. Taur. (infra, 91-96). 
indicates how literally the dream carried out the wish of Zeus. In the present passage in the Odyssey the amoebaean form which the poet gives to his description of the dream confines the charge of Athene to general terms. The orders are not given in the original words of Athene, but are reported briefly, sketched only in the vaguest outline (800-801):

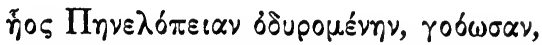

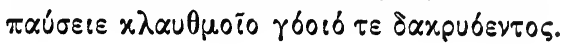

If Athene had demanded of the dream that it should carry a verbatim message to Penelope, a dialogue would have been either impossible, or else so mechanical as to preclude any impression of epic verisimilitude. Here the spontaneity of the dialogue is preserved by controlling the form of the goddess' communication. The dramatic force of the incident is greatly enhanced by this innovation. In Iliad 2, one knows in advance what the dream will say; but here the treatment is more subtle. There is effectively introduced the element of suspense. What form will the words of comfort take? What news of importance to the story will the dream impart? Will it refer only to the departure of Telemachus, or will it announce that Odysseus is alive and on his homeward journey? The answers to these questions the reader does not know until the dialogue is ended; there is no anticipatory address to Iphthime, as there is to "Oveıpos. ${ }^{80}$ The word for word repetition of Iliad 2, essential in the ballad, but an accident in the epic and not of its essence, is omitted in this later, more studied example of the employment of the dream.

Another innovation is to be noticed in the change in the sex of the recipient of the dream. Athene sends her phantom in sleep to a woman, whereas the visions of the Iliad come to males. ${ }^{81}$ Granted that the greater rôle played by the female personae in the Odyssey helps this change in convention, still

${ }^{80}$ That is in Iliad, 2, 11-15, referred to above, 26.

81To Agamemnon in Iliad, 2, 1-47; to Rhesus in 10, 496-497; to Achilles in $23,62-107$. 
that one factor alone is not serious enough wholly to condition the change. Odysseus is quite as much the hero as Penelope is the heroine of the tale, and there are evident in it no natural difficulties to prevent the poet from sending dreams to his hero. $\mathrm{He}$ does indeed send numerous waking visions to his male characters throughout this epic. ${ }^{82}$ The Iliad is a saga of males. The female figures, Helen, Briseis, Chryseis, are assumed as a necessary part of the story, form a background for the action of the heroes, but never play more than a passive rôle. To send dreams, therefore, to the male heroes is natural and largely dependent upon the conditions imposed by the narrative. But no condition such as would demand a different convention controls the practice in the Odyssey. The poet's preference for sending dreams to his heroines rather than to his heroes would seem to be the result, then, of deliberate design. There are no data for determining whether this change was original with the poet or for deciding what factors influenced him in his choice. Though later epic poets did not see fit to follow him, the tragic poets, at any rate, found his practice congenial and sent dreams to women. ${ }^{83}$

\section{Odyssey, $6,13-51$}

In Odyssey, $6,13-51$ is the story of Nausicaa's dream, in which she is directed to go to the shore, ostensibly to wash her shining raiment, but actually so that she may aid the ship-

${ }^{82} \mathrm{Athene}$, for example, appears in a waking vision to Odysseus, $1,118 \mathrm{ff}$; to Telemachus, taking on the likeness of Mentor, 2, $399 \mathrm{ff}$.; in the guise of a youthful shepherd, to Odysseus, 13, $221 \mathrm{ff}$.; in the form of a woman fair and tall, to Odysseus, 16, $155 \mathrm{ff}$.

${ }^{83}$ In the tragedy of the classical period there is just one exception to this convention. In the plays which portray dreams, Aeschylus, Persae, Choephori, Eumenides, Sophocles, Electra, Euripides, Hecuba, Iphigenia Taurica, the woman is the recipient of the dream. As in the realm of the supernatural the oracle is regularly sent to the man, so the dream is sent to the woman. The one exception in regard to the dream is found in the Rhesus, 780-788. There the poet, following the story of the Iliad, reverts to the convention of that earlier work. See infra, 65, n. 252, for further comment upon this feature. 
wrecked Odysseus. Athene is again the active divinity, as in $4,787-841$; but instead of sending a phantom, as she did before, she comes in person (15). Note how much in the descriptionin accord with the universal tendency of the epic to use formulae -has become stereotyped even thus early. The goddess comes quickly, even 'as a breath of wind' $(20) ; 84$ she enters though the doors are shut $(19) ;{ }^{85}$ she stands above the head of Nausicaa (21) $;{ }^{86}$ she likens herself to the daughter of Dymas, a friend of equal age with Nausicaa, dear to her heart (22-23), as Iphthime was to Penelope; ${ }^{87}$ she directs Nausicaa what she is to do (31 ff.). ${ }^{88}$

The experiences of the dream are here, as before, looked upon as real occurrences, which are as actual to the mind of the princess as her waking visions. There is no suggestion of a dream state. In this respect the dream is cut on the usual pattern of the dream in the Homeric poems. It is non-allegorical; it gives its commands in a straightforward manner without need of interpretation. The goddess appears to a woman;89 in this matter the poet employs again the innovation noticed in the preceding dream. But outside of that feature this dream is closely akin to the primitive vision of Iliad 2 .

The place of introduction of the dream is again a crisis, a pivotal point in the story. For from this incident the lot of Odysseus changes, his ill-luck seems at last to end. The value of the dream, in this passage, for the economy of the plot is explicit and direct. It is in pursuance of the dream's mandate that Nausicaa goes to wash her raiment and so meets Odysseus on the shore. From that encounter all his blessings flow. This meeting introduces the whole Phaeacian episode. Nausicaa

${ }^{84}$ Compare Iliad, 2, 17, and supra, 6, n. 21.

${ }^{85}$ Compare Od. 4, 802; 838.

${ }^{86}$ Compare supra, 6, n. $2 ?$.

${ }^{87}$ For other dream disguises of the early epic, cf. Iliad, 2, 21; 10, 496; Od. $4,787 \mathrm{ff}$.

${ }^{88} \mathrm{Cf}$. Iliad, 2, 28.

${ }^{89}$ Od. 4, 787-841; supra, 27, n. 81; infra, 65. 
guides Odysseus to her father's court, where he makes himself known to the king. Alcinous feasts him and draws from him, on two successive nights, ${ }^{90}$ the story of his ten years of adventure since the fall of Troy, a narrative which Homer, true to the principle which Horace later formulated for him, ${ }^{91}$ had previously omitted. He finds favor in the king's eyes and is escorted on the magic ship, the speed of which excelled the hawk's, back to long-sought Ithaca, ${ }^{92}$ where in one short week the story hastens to its close. For importance to the development of the plot this dream stands second to the pernicious dream of Iliad $2 .{ }^{93}$

\section{Odyssey, $19,509-581$}

The third dream of importance in the Odyssey is entirely different in content and form from every other dream of the early epic. It is Penelope's dream of the geese and the eagle, which she tells to the still unrecognized Odysseus. It is a dream in which appear animate objects, but no persons. ${ }^{94}$ It is an allegorical dream, a dream that demands and yet at the same time contains its own interpretation. An eagle came from the mountain and killed Penelope's twenty geese; as she lamented the loss, a second time it came, and, perching upon a rafter, proclaimed itself Odysseus. It then explained the first or

${ }^{90}$ The story of his wanderings, which he tells to Alcinous, comprises books 7-12.

${ }^{21}$ Epp. 2, 3, 148-149:

semper ad eventum festinat et in medias res non secus ac notas auditorem rapit . . .

${ }^{92}$ The story of his return is told in Od. 13.

${ }^{93} \mathrm{Od} .15,1-43$, the appearance of Athene to Telemachus, is quite indubitably a waking vision. It lacks entirely the elaborate framework which we have found in the dreams. Furthermore the poet is explicit (7):

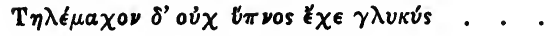

${ }^{94} \mathrm{I}$ have summarized the forms in which the Homeric dream appears, infra, 51-52. See the footnotes to those pages. 
allegorical part of the dream: the geese were the suitors, the neagle Odysseus, arrived to bring doom upon his false friends. $\mathrm{n}$ This interpretation, included within the dream itself, Odysseus (will not disturb (555-557):

$\mathrm{t}$

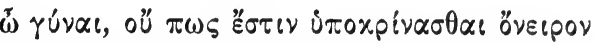

$\mathrm{c}$

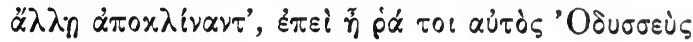
$\pi \varepsilon \dot{\varepsilon} \phi \alpha \delta^{\prime}$ ö $\pi \omega \varsigma \tau \varepsilon \lambda \varepsilon \varepsilon_{\varepsilon} .^{95}$

But Penelope is not yet satisfied that the dream is sure of fulfilment. Not all dreams come to pass for mortals. For there are two gates of fleeting dreams, one of horn, through which pass visions that bring true messages for men, the other of ivory, which gives egress to deceitful dreams. ${ }^{96}$

From the standpoint of its relation to the plot this dream forms the prelude to the last great act of the Odyssey, appearing immediately before the trial of the bow, the slaughter of the suitors, and the restoration of the long-wandering hero to his home. It cannot, however, be rated with Iliad 2, $1 \mathrm{ff}$. or Odyssey, $6,13-51^{97}$ for its influence upon the plot, for the assistance it gives in advancing the action. Penelope has already determined to abide the trial of the axes and to follow the lot of the successful contestant. ${ }^{98}$ The dream does not affect this decision. The most that it does for the actors of the poem is to give them

${ }^{95}$ This passage, conveying one meaning to Penelope and another quite different to the audience, is an early example of that tragic irony which finds its grandest example in the Oedipus Tyrannus of Sophocles.

${ }^{96}$ For the many echoes and imitations of this description of the gates of dreams (quoted below, 35), compare infra, 44-46, and the footnotes there.

${ }^{97}$ Supra, $2-9 ; 28-30$.

${ }^{98}$ Penelope expresses her fear that the dream may be deceitful, in spite of the confident interpretation of the stranger (Odysseus), and tells him of the contest which she has determined upon for the following day, a contest in which she herself is to be the prize for the successful suitor, $570-581$. 
hope in varying degrees. Odysseus is sure that the suitors will perish at his hand (557-558). Penelope, who would gladly take comfort from the dream, can only wistfully express her hope that it came not through the gate of ivory (568-569).

The encouragement given by the vision steadies and strengthens the action, but does not originate it or control it as the dreams cited above controlled the action. ${ }^{99}$ But the effect at this crisis on the mind of the reader is impelling. As a part of the elaborate epic properties with which the stage is set for the great scene of the last act, it strikes the keynote of what that scene shall be. It prepares for the quick ending of the ten years' wandering and suffering of Odysseus and for the quick coming of the reward for his faithful wife. It gives an atmosphere of swift decision and rapid disaster and restitution. And so, though the rôle which the dream plays in the structure of the plot is small, it does not follow that the epic writer was toying with his device, or adding it as a mere prettiness. That degradation of the dream device was left to Euripides, ${ }^{100}$ the earliest of the Alexandrians. ${ }^{101}$ Here the part the dream plays is still impressive and significant for what it adds of the intangible in tone and color, suggesting an impending crisis and hinting broadly at the solution of the story, though not actually guiding the catastrophe.

The nature and the number of epithets applied to dreams in these lines are worthy of note: dreams are $\alpha u \eta^{\prime} \chi \alpha \nu o$, 'inexplica-

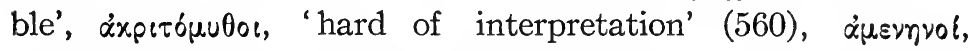
'fleeting', 'unreal', 'unsubstantial' (562), an adjective in these early epics regularly used of ghosts or of the disembodied spirits

${ }^{99}$ Iliad, 2, 1-47; Od. 6, 13-15.

${ }^{100 I}$ refer here to the dream in the Rhesus, 780-788. For the discussion of the mean rôle it plays, see below, 98-100.

${ }^{101}$ Euripides as the precursor of Alexandrianism is a commonplace of the handbooks. Cf. especially, Couat, vi, and 59. 
of the dead;102 they deceive, ${ }^{10} \lambda \varepsilon \phi \alpha i p o v \tau \alpha \iota,{ }^{103}$ and bring words

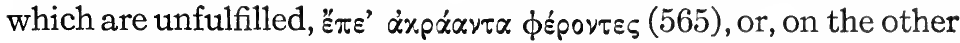

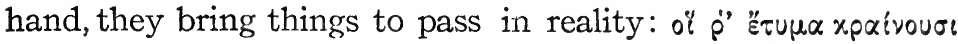
(567). The writer has gone far from the o o $\lambda_{0 \varsigma}$ "Ovecpos ${ }^{104}$ of the earlier work.

The most remarkable difference, however, is the changed conception of the dream. The first portion of it is allegorical:

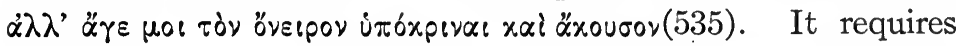
nterpretation. This is a new departure for the epic and a nodel for the allegorical dreams of tragedy. ${ }^{105}$ To be sure

${ }^{102}$ This connotation emphasizes the partial dependence of the eschatology of all peoples upon dream experiences; see the discussion and bibliography in note 40, above, and add the following references for comment on additional features: Frazer, Belief in Immortality, 1, $27 \mathrm{ff} . ; 136$; 139; $141 ; 193 ; 321$; Golden Bough, Index, s. v. Dreams; Hardie, Lectures, 91 ff.; Granger, 33; 42; Tylor, 1, 430; 440 ff. The close relationship between the descriptions of the dream and of the ghost, in similarity of action, of imagery, and of vocabulary, in Greek or Roman epic, appears in the following passages: Iliad, 23, 72; 97-98; 100; 104; Od. 4, 824; 835; 11,$83 ; 206-207 ; 211-213 ; 222 ; 476 ; 20,355 ;$ Aeneid, 1,$353 ; 2,772 ; 773$; $793 ; 4,353 ; 554-572 ; 5,636 ; 736 ; 6,390 ; 480 ; 894 ; 10,519 ; 636$; 641-642.

${ }^{103} \mathrm{Iliad}, 1,63$ and 5, 149-150 admit inferentially that dreams may need interpretation, that is, may be allegorical and capable of misconstructions, unless we reject, with Hey, 11 (see above, n. 24), the equation $\delta \nu \epsilon \iota \rho \circ \pi \delta \lambda_{0 s}=$ 'interpreter of dreams'. If $\delta \nu \epsilon \iota \rho \circ \delta \boldsymbol{\lambda}$ os were used in the passage in the text, it would certainly mean 'interpreter of dreams', as it surely does in Herodotus, 5, 56 and probably in 1, 128 also. Cf. also Buchholz, 2, $33 \mathrm{ff}$., the chapter entitled, Die Seher.

${ }^{104}$ Iliad, 2, 1-47 (supra, 2-9). Hey, 16, insists that the nature and the number of epithets support the theory of a later interpolation.

${ }^{105}$ The allegorical dream is the usual form of the dream in tragedy; it is more congenial to the nature of that literary genre, as indicated infra, 56-59. The allegorical dreams in classical Greek tragedy are: Aeschylus, Pers., infra, 64; Prom. Vinc., irfra, 69; Choe., infra, 71; Sophocles, Electra, infra, 84; Euripides, Iph. Taur., infra, 91 ff.; Rhesus, infra, 97. The non-allegorical dreams are in the Eumenides, infra, 77; and in the Hecuba, that part of the queen's dreams which has to do with Polyxena: that which is concerned with Polydorus is portrayed as external in origin; infra, 90. 
there is one hint, possibly two, in the earlier work, of a knowledge of the nature of the dream, that the vision may exist only in the mind of the dreamer and correspond to no external objective thing. These are the assumptions of Iliad, 22, 199$200,{ }^{106}$ and also of the reference to $6 v \varepsilon \iota p o \pi \delta \lambda_{0 \varsigma}$ in Iliad, 1, 63 and 5,149, if this word does not mean rather 'one to whom dreams come'. ${ }^{107}$ But this dream of Penelope is the first allegorical dream in extant Greek literature. Dreams which presumably demanded interpretation must, from the physical nature of dreams, have been frequent in the everyday life of mankind from most primitive times. Hence it is difficult fully to realize how slow and halting is the process of transferring such experiences to the realms of literature. One has only to recall, however, the resistance which the different departments of modern literature, for example the novel, have offered to the adoption of changes, obvious enough after their incorporation, to appreciate fully the advance which the account of Penelope's dream marks. When the mould was once cast, other poets could imitate and refine the technique.

The lack of familiarity on the part of the poet with his new dream form leads him into a strange contaminatio in this passage. The second part of the dream, in which the eagle returned and announced itself to be Odysseus and interpreted the first or allegorical part of the dream, shows that the poet felt uneasy in connection with a vision which is not direct,- - a vision, that is, the symbols of which must be translated if its meaning is really to be grasped. And so the poet adds a second part in the manner of the older type, the objective dream, which was direct and told its own story, that his hearers or readers might not be confused by the novelty which he had introduced. Later writers handle the interpretation of the allegorical dream

${ }^{106}$ Aristarchus athetized lines 199-201, which contain the offending conception, and some modern editors have followed him. Ameis-Hentze, Anhang, ad loc., give the evidence and the bibliography.

${ }^{107}$ See Rohde, 1, 37; Nägelsbach, Nachhom. Theol. 172; supra, 6, n. 24, and 33, n. 103. 
with the greater skill which comes of practice. But there is much charm in the rough pioneer work displayed in the economy of this Homeric dream and there is no lack of artifice and polish in its details.

Among these highly sophisticated details is Penelope's statement about the two gates of dreams (562-567):

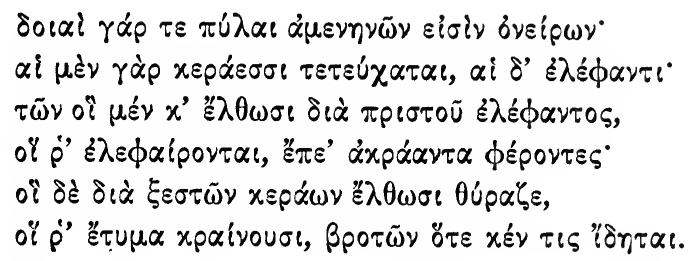

The conscious artifice in these lines is shown in the play ${ }^{108}$ upon the similarity of sound in $\varepsilon \lambda \varepsilon \dot{\phi} \phi \nu \tau \iota$, $\varepsilon \lambda \varepsilon \phi x i p o \nu \tau \alpha \iota$, and $x \varepsilon p \dot{\alpha} \varepsilon \sigma \sigma \iota$, xpalvouo - a play which can hardly be accidental. The epic masterpiece is always the product of an advanced art, and so this intermixture of art with artlessness, the ingenious with the ingenuous, the embellished with the unembellished, does not of itself argue a date of the time of Hesiod, or later, for this passage on the gates of dreams. ${ }^{109}$ To be sure, the predominant note in the Homeric dream, as the discussion hitherto has shown, is, artistically, the rudimentary, the early, the primitive. But the acknowledgment of this feature does not exclude the recognition of the presence of later, less rudimentary elements. A combination of the old and the new, such as exists in the descriptions of the dream and in about the same proportions, can be illustrated in conjunction with a survey of the companion and allied conceptions, sleep, death, the land of dreams.

${ }^{108}$ This word-play was noticed as early as the scholiast; cf. his comment on line 562 .

${ }^{109} \mathrm{Hey}, 15$, discussing the dream from the philosophic side, excludes everything from the 'original' Homer which does not conform to his theory of the "exoteric" dream. He says of the word-play under discussion: "Solche Wortspiel verbricht kein homerischer Dichter, sondern höchstens ein vernünftelnder Katalogiseur hesiodischer Schule". 
In the portrayal of sleep, for example, in the Iliad and the Odyssey, we find the same duality of artistic theory-the naive picture of external, objective sleep, existing side by side with descriptions containing such adjectival and verbal adjuncts as seem to indicate a more advanced psychology and so sound quite natural to a modern ear. What proportion of this objectivity is a survival of an earlier belief and what proportion can be ascribed to conscious artifice there is no means of determining. In a given passage sleep may be at the same time a personal deity and a substance that can be poured upon mortals by that deity; and at once the two conceptions may be linked with

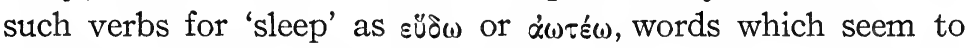
contain essentially the modern idea. The noun for 'sleep' is found with many epithets which are figurative in origin, however much consciousness of the figure may have been lost.

Some epithets of sleep are common to both poems. Thus,

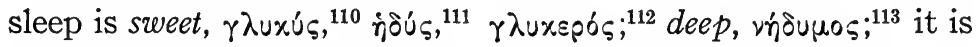
soft, like the fresh-plowed fallow, or the grassy meadow, or the unshorn sheep, $\mu \alpha \lambda \alpha \times \sigma_{s} ; ;^{114}$ it is the all-subduer, the all-tamer, $\pi \alpha \nu \delta \alpha \mu \alpha \tau \omega \rho^{115}$ In the Odyssey, especially, 一an indication perhaps of a later technique - several of these adjectives show a slightly greater tendency to become stereotyped, as the approximate count of my footnotes shows.

The Iliad further calls sleep ambrosial, $\alpha \mu \beta p o ́ \sigma \iota_{0},{ }^{116}$ an epithet used of night and things pertaining to the gods, their hair, their sandals, their anointing oil; like wine, it is sweet to the mind, $\mu \varepsilon \lambda i \phi \rho \omega \nu ; 117$ it is gentle and balmy, like a warm wind, $\dot{\alpha} \pi \dot{\eta} \mu \omega \nu$

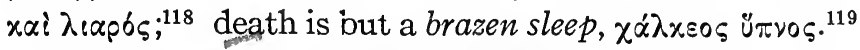

The later poet adds some touches of his own to the picture. With him sleep is also, on occasion, merciless, cruel, like an Achilles, a Patroclus, or a Zeus, $\sigma \chi \varepsilon \varepsilon^{\prime} \lambda_{105}, 1^{120}$ it is pitiless,
${ }^{110}$ Iliad, 3 times; Od., 11 times.
$1162,19$.
${ }^{111}$ Iliad, once; Od., 5 times.
${ }^{117} 2,34$.
${ }^{112}$ Iliad, 3 times; Od., 4 times.
${ }^{113}$ Iliad, 7 times; Od., 5 times.
$11814,164$.
${ }^{114}$ Iliad, twice; Od., once.
$11911,241$.
${ }^{115}$ Iliad, 24, 5; Od. 9, 373.
12010,69 . 
relentless, like the sword of steel or the day of death, $v \eta \lambda \eta_{s} ;^{121}$ it relaxes the limbs, $\lambda u \sigma u \mu \lambda \eta^{\prime} \varsigma^{122}$ as does love in Hesiod ${ }^{123}$ or Sappho, ${ }^{124}$ death in Euripides, ${ }^{125}$ wine in the Anthology, ${ }^{126}$ or the Furies in the Orphic Hymn; ;27 it has its gifts, of which man par-

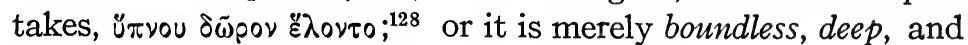

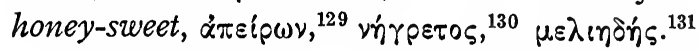

In the use of verbs with the noun for sleep as subject the variety is equally great in the two epic poems. Each shows approximately a score ${ }^{132}$ of different verbs so used; the total number of occurrences is greater in the Odyssey in proportion as the theme of sleep plays a more important rôle. In the Iliad

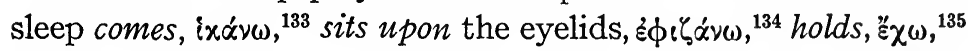

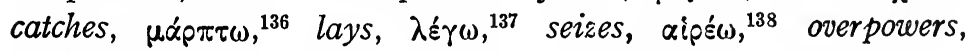
$\delta \alpha \mu \alpha{ }^{\prime} \zeta{ }^{139}$ rushes violently at, like a hound that rushes upon a

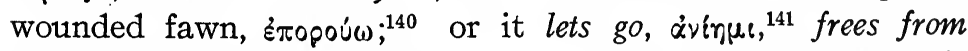

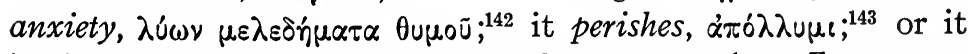
is pictured as a liquid and is poured upon mortals as Zeus pours rain, $\chi \hat{\varepsilon} \omega .^{144}$

Of these verbs the Odyssey repeats many: ${ }^{\prime} \chi \omega,{ }^{145} \chi \chi^{\prime} \omega,{ }^{146} \dot{\alpha} v i \eta \mu \iota,{ }^{147}$

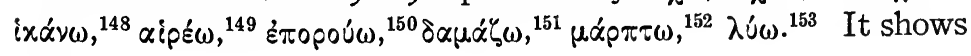
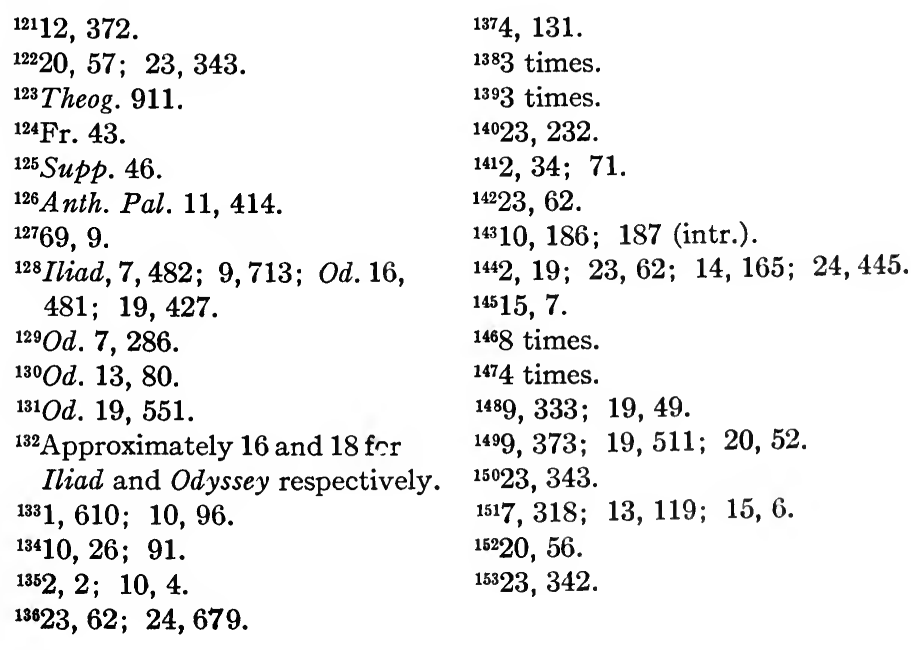


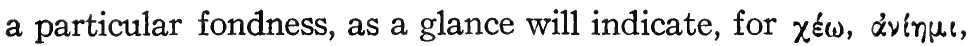
$\alpha i p \varepsilon \omega, \delta \alpha \mu \alpha^{\prime} \zeta_{\omega},{ }^{154}$ and in the case of the others it often imitates passages from the earlier poem. ${ }^{155}$ It also adds several, some colorless, some highly figurative. Sleep is used with the wonted

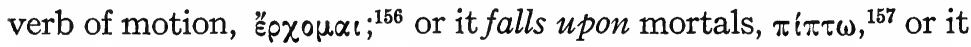

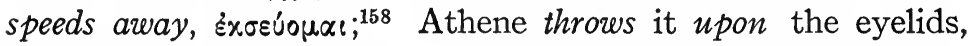
$\beta \alpha \lambda^{\prime} \lambda \omega{ }^{159}$ it joins with the evil companions of Odysseus to

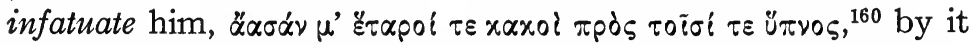
are men sated, $\alpha \dot{\alpha} \delta \dot{\varepsilon} \omega,{ }^{161}$ or worn out, $\dot{\alpha} \rho \dot{\alpha} \omega,{ }^{162}$ or caused to forget, $\varepsilon \pi \imath \lambda \dot{n} \theta \omega .{ }^{163}$

After a survey such as this from the Index Homericus one gets no nearer, perhaps, to the poet's explanation of the psychic processes of sleep, if he had any such explanation. Furthermore, many of the ideas can be exactly paralleled in modern poetry in the works of authors to whom the scientific phenomena of sleep are no closed book. It is not a question, then, of the epic poet's psychological or philosophical theories as to the nature of sleep, but a question of what his prevailing artistic conception was. Viewing the Homeric treatment from this latter standpoint, we may say that the cumulative evidence of so many touches leaves an undoubted impression of sleep as something external, objective, corporeal. Whether the portrayal is in accord with the writer's scientific belief, or is only his poetic fancy, sleep nevertheless appears as something material, physical, existing outside the sleeper.

When one has accustomed oneself to this recurrent and artistically primitive giving of substance to sleep, one is prepared to accept without surprise the detailed pictures of sleep as a personality and a god. Hence, in spite of the elusive dualism, the occasional combination of a primitive psychology

$\begin{array}{ll}{ }^{154} 8,4,3,3 \text { times respectively. } & 1591,363 ; 16,450 . \\ { }^{155} \text { Cf. Iliad, 23, } 62 ; 24,679 ; \text { Od. } 20, & 16010,68 . \\ 56 ; 23,342 ; \text { etc. } & 16112,281 . \\ 1565 \text { times. } & 1626,2 . \\ { }^{157} 4 \text { times. } & 16320,85 . \\ 15812,366 . & \end{array}$


with intimations of a more enlightened view of sleep and dream experiences, the picture of Sleep in Iliad 14 and 16 does not strike one with that high degree of artificiality and unreality which attends the personification of those pale abstractions which we find so freely introduced by a Silius Italicus ${ }^{164}$ or a Valerius Flaccus. ${ }^{165}$ This full-length portrayal of Sleep in Iliad 14 and 16 does not suggest, in the same way, the study and the lamp. To be sure the naiveté of Homeric epic is an artistic naiveté. ${ }^{166}$ Yet one must admit that the picture of Sleep, thus personified, glides into the mind of the reader here without any lack of verisimilitude. Sleep is here as truly a god as Zeus or Aphrodite, if on a lower plane.

In Book 14, $225 \mathrm{ff}$. Hera speeds to Lemnos, city of divine

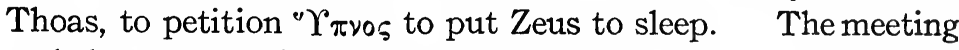
and the conversation are most natural and vivid. No divinity could be more completely equipt with all the attributes of personality than Hypnos is in these verses. Hera in return for this favor will give him a fair golden throne, imperishable forever, with a footstool for him to put his gleaming feet upon (238-241). But Sleep is cautious of granting her request. His previous plot against Zeus, when the latter, after awakening, tossed the gods in anger about the Olympian mansion and forced Hypnos to flee for refuge to $N u ́ \xi$, of whom even Zeus stood in awe, had fallen too little short of disaster. So Hera is forced to offer him one

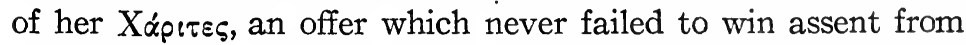
male divinity. Hypnos puts her to a solemn oath, invoking all the gods by name, then promises to do her bidding. He accom-

${ }^{164}$ Cf. $2,548-552 ; 4,89 ; 7,204 ; 10,345 ; 13,560$; and passim.

${ }^{165}$ Cf. 1,$796 ; 8,70$. The personifications of Sleep, Death, and similar conceptions in the Latin poets are of a purely literary character; cf. the passages referred to under the words, Somnus, Mors in J. B. Carter, Epitheta Deorum (Leipzig, 1902).

${ }^{166}$ We must remember what Professor K. F. Smith so judiciously says, Elegies of Tibullus, page 68 (New York, 1913): "No competent critic in these days, certainly no classical scholar worthy of the name, needs to be reminded that in a literary masterpiece simplicity is always deliberate and naiveté always artistic". 
panies her to Mt. Ida and, taking on the likeness of a bird, ${ }^{167}$ nestles in the highest tree (286 ff.), waiting to do his part. At the right moment he puts sleep as a cloak around Zeus (359), and dashes off to Poseidon to deliver the injunctions of Hera. A short passage here, 352-360, combines all the different conceptions with delightful inconsistency- $\varepsilon \tilde{u} \delta \varepsilon \varepsilon \alpha \tau \dot{\eta} \rho$ (352), $\check{\pi \nu \varphi ~ . ~ . ~ . ~}$ $\delta \alpha \mu \varepsilon i \varsigma$ (353), $\mu \alpha \lambda \alpha x \dot{\partial} \nu \pi \varepsilon p i x \tilde{\omega} \mu^{\prime} \varepsilon \dot{\alpha}^{\prime} \lambda u \varphi \varphi \alpha$, the material in the hands of Hypnos (359)-without detracting in the slightest degree from the personality and verisimilitude of Sleep.

In Iliad 16, too, we find a personal Hypnos linked with a personal Thanatos. The body of Sarpedon is given to the 'swift conveyors', the twins Sleep and Death $(454 ;$ 681-682), who carry it quickly to Lycia. ${ }^{168}$

Death and Sleep are joined as brothers in these two passages (Iliad, 16, 454, and 682). In later literature the idea is widespread. Hesiod, who elaborates still further the relationship between Sleep and Death, calls them children of Núg. ${ }^{169}$ One of the scenes on the chest of Cypselus, as described by Pausanias, ${ }^{170}$

${ }^{167}$ For a note on dreams and the comparison of them to bats, etc. see below, $A 3 ; n$. 184. The conception of sleep as winged does not occur until the Alexandrian period. Callimachus, Hymn to Apollo, 234, supplies the earliest extant reference to the wings of Sleep. This may be a development of the hint given in this Homeric passage. After the Alexandrian age the conception is frequently met; cf. Tibullus, 2, 1, 89; Nonnus 5, 411; 31, 175 (ed. Ludwich, Leipzig, 1909); Fronto, De Feriis Alsiensibus, 229 (ed. Naber); Claudius, In Rufinum, 2, 325 (ed. J. Koch, Leipzig, 1893).

${ }^{168}$ Sleep and Death, carrying off a long-haired hero, either Memnon or Sarpedon, have been portrayed on Greek vases. Cf. for the illustration, Baumeister, 1, 727, fig. 781; and for the discussion and literature, 2, 922; and Preller-Robert, 1, 844-845.

${ }^{169}$ Theog. 212; 756-759. Sleep is child of Night also in Euripides, Cyclops, 601; Nonnus, 31, 117; etc. Dreams are the children of Night in Hesiod, Theog. 212; Euripides, Hec. 70; Ovid, Fasti, 4, 662; and they accompany Sleep in Ovid, Met. 11, 613 and Statius, Theb. 10, 112, while Sleep is king of Lucian's Isle of Dreams, Ver. Hist. 2, $32 \mathrm{ff}$.

${ }^{170}$ Pausanias, 5, 18, 1; cf. Frazer, Pausanias, ad loc. and on 2, 10, 2. Here Sleep is represented passively, as slumbering; compare the citation below, n. 181, where Sleep is active, lulling to rest a lion. 
represented Sleep and Death reposing in the hands of Night. Sleep was clad in white and slumbered in the right hand of Night; Death was clad in black and slumbered in her left. Though this particular composition is not fully paralleled on the extant vases, Sleep and Death do appear together on the vases. Attic lekythoi portray them so. ${ }^{171}$ Plutarch, Cleom. $9,{ }^{172}$ says that there was in Sparta a shrine to Death. Sisyphus tricked and bound Death, a theme used by Aeschylus for a satyr drama. ${ }^{173}$ Euripides boldly portrayed Death upon the stage, with lowering mien, black wings, and a knife with which to cut from the dying a lock of hair. ${ }^{174}$ This gloomy conception of Death was not, however, universal. Where the similarity of Death to Sleep was realized on its beneficent side a milder conception of Death was the rule. Thus Sophocles ${ }^{175}$ called

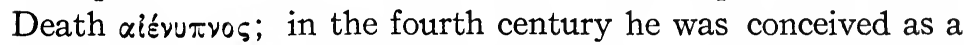
young man, until finally he was likened to an Eros, winged or unwinged, usually sleeping. Then entered the euphemistic use of Sleep for his brother Death. ${ }^{176}$

But let us return to the matter more immediately in hand. This very live and vivid picture of Sleep and the portrayal of a

${ }^{171}$ Cf. Robert, Taf. 2, p. 20. For numerous representations of Death on Athenian lekythoi, cf. Dumont et Chaplain, Les céramiques de la Grèce propre, par. 1, p1. 27-28 (Paris, 1888-1890); Baumeister, 3, 1729.

${ }^{172}$ Cf. also Pausanias, $3,18,1$. See Preller-Robert, 1, 843 for bibliography.

${ }^{173}$ See Preller-Robert, loc. laud., footnote 5.

${ }^{174}$ Alcestis, $25 ; 261 ; 843 ; 1140$. Robert, 34 ff. discusses this portrayal at length.

${ }^{175}$ Oed. Col. 1578.

${ }^{176} \mathrm{~A}$ very valuable presentation of the conception of Death which was held by the Greeks of the Classical period can be found in A. de Ridder, De l'idée de la mort en Grèce à l'époque classique (Paris, 1896). See also A. Maury, Du personnage de la mort et de ses représentations dans l'antiquité (in Rev. Arch. 1847-1848); Robert, Thanatos. Robert, 36 ff., finds no popular cult of Death corresponding to the plastic and pictorial representations. 
likewise personal Death must be kept in mind in studying the poet's conception of the dream, because of the close interdependence of these three conceptions. For, to the two brothers, Sleep and Death, Dream, or the race of dreams, was related. ${ }^{177}$ In the Hesiodic passage cited above, ${ }^{178}$ Night was their mother as she was of Sleep and Death. Euripides calls them black-winged children of Earth;179 Sophocles ${ }^{180}$ makes Death the son of Earth. Again, the statues of Sleep and Dream in the inner chamber of the enclosure of Asklepios at Sicyon ${ }^{181}$ repeat the family connection of the dream with Sleep and Death.

Since, then, Homeric epic connected the dream with these predominantly external and personal daimons, the additional picture of a country and dwelling-place of dreams, $\delta \tilde{\eta} \mu \circ 5$ oveip $\omega \nu$, was a natural extension. This home of dreams is situated beyond the streams of Oceanus and the White Rock, beyond the gates of the sun, near the asphodel mead which the shades of heroes haunted, Odyssey, 24, 11-14. By comparing this passage with Odyssey, 11, 14, we see that the region is further defined as the land of the Cimmerians.

The interest which these descriptions of the country of dreams aroused is shown by the wide-spread imitation of them. Vergil follows Homer ${ }^{182}$ in speaking of a home of dreams; he places the home of vain dreams primis in faucibus Orci, and represents

${ }^{177}$ For the representation of the family relationships supplied by art: see note 174 above.

${ }^{178}$ Theog. 212. Cf. n. 169.

${ }^{179} \mathrm{Hec} .70-71$. Compare this passage with Iph. Taur. 1262-1263.

${ }^{180}$ Oed. Col. 1574.

${ }^{181}$ Pausanias, $2,10,2$. In the outer chamber of the sacred enclosure was the head of a statue of Sleep; in the colonnade a statue of Sleep and a statue of Dream. In this representation Sleep is active, putting a lion to sleep; cf. G. Krüger, Hermes und Hypnos, (in Fleckeisens Jahrbücher, 9, 288-301), and other bibliographical references in Frazer's Pausanias, ad loc.

${ }^{182}$ It must always be remembered, however, that the Vergilian Hades is subterranean, while the Homeric Odysseus does not find the shades beneath the earth at all. 
such dreams as clinging beneath all the leaves of a huge black elm (Aeneid, 6, 273, 282-284). The source of this dream-elm is undetermined. ${ }^{183}$ The continual likening of the soul to the dream-image suggests that, as souls are compared to bats (Od. 24, 6 f.), Vergil is here transferring to the companion conception of dreams the bat-like habits of the souls of the suitors which Hermes was conducting to the mead of asphodel. ${ }^{184}$

Ovid, Met. 11, 592-593, places his home of Sleep and its creatures, dreams, near the Cimmerians:

est prope Cimmerios longo spelunca recessu, mons cavus, ignavi domus et penetralia Somni. ${ }^{185}$

Apuleius, Met. 6, 21, has Psyche bring up her box of infernus somnus ac vere Stygius from the home of Proserpina. Lucian, Vera Hist. 2, 32, has an island of dreams. The late writer

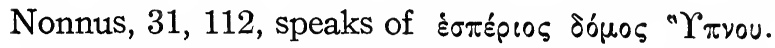

These are literary, artistic extensions of what their authors found in their predecessors, with no relation to contemporaneous

${ }^{183}$ See Hey, 17.

${ }^{184} \mathrm{This}$ picture of the dream-elm in the entrance of Hades contradicts the later passage, 6, $893 \mathrm{ff}$., in the opinion of Norden, 47 (he quotes in support A. Gercke, Neue Jahrbücher f. d. klass. Alt. 1901, 110 f.). Norden, 216, cites parallels: the tree of the Hesperides, the golden apples of which Heracles had to pick before he could receive immortality, a myth of chthonic character, in which the Hesperides were originally pictured as birds; Lucian, Ver. Hist. 2, 33, the Island of Dreams with the wood in which the bats nested. Souls, which by a process of idealizing personification were later looked upon as 'winged', were originally conceived as birds. Vergil, who here evidently pictures dream-beings under the form of soulbeings, reverts to that primitive conception.

${ }^{185}$ The whole of the long passage should be read in this connection. A comparison of the Hypnos of the earlier poet with the Somnus of Ovid here, or the pale Somnus-Scpor of Silius Italicus, 10, $340 \mathrm{ff}$., will give a clear insight into the difference in treatment between the old classic picture of Sleep and the later imitation. In the Ovidian reference an intermediate Greek source-'Alexandrian' shall we say?-seems to be indicated by the Greek names of three of the thousand sons of Somnus, Morpheus (635), Icelos-Phobetor (640), and Phantasos (642). 
folk-beliefs or philosophical theories. Their sources are entirely bookish. When one gets back to Homer, however, that assumption cannot be so confidently made. Homeric epic was much nearer the soil and the incorporation therein of such portrayals as that of the country of dreams may represent current folkbeliefs.

To the country of dreams gates are given in two places in the Odyssey -in 4, 809, where the phantom Iphthime, sent by the gleaming-eyed Athene, finds Penelope 'very sweetly slumbering at the gates of dreams', and in the longer passage, 19, 562-567. ${ }^{186}$ The allusions to these lines and the imitations of them are numerous in both Greek and Latin literatures: Plato, Charm. 173a:

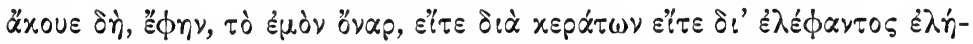
$\lambda \cup \theta \varepsilon v$; Sophocles, Elect. 645, perhaps (one may see a hint of it in

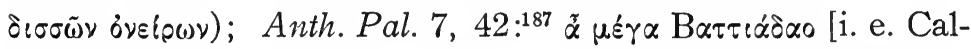

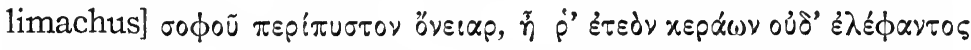
हैทs; Horace,Carm. 3, 27,41: ludit imago vana quae porta fugiens eburna somnium ducit?; Propertius, 5, 7, 87; Statius, Silv. 5, 3, 287; Lucian, Ver. Hist. 2, 32; Somn. 6; Macrobius, Somn. Scip. 1,3,20; Tertullian, De An.46; Philostratus (Maior), Imagines, 333, 1-3 (Benndorf and Schenkel, Leipzig, 1893); Babrius, Fabulae, 30, 8 (Schneidewin, Leipzig, 1880); Julian, Epistolae, 17 (Hertlein, Leipzig, 1875); Nonnus, Dion. 34, 90; 44, 53; and Coluthus, Raptus Helenae, 367 (Abel, Berlin, 1880). But the most famous of all the imitations is the account of the twin

${ }^{186}$ The lines are quoted in full above, 35 .

${ }^{187}$ For a discussion of this poem from the Anthology and the light which it throws upon the 'Alexandrianism' of Ennius see Messer, 78-92. This discussion, indeed, is, in addition to being an independent study in the dream technique of the classical Greek period and to that extent an end in itself, a preliminary survey of the pre-Alexandrian elements. My final aim is to sift and classify the elements-in whatever sphere they liewhich went into the make-up of the description of dreams in Latin literature: to determine which of these elements are native, which Alexandrine, which go back to the classical Greek period. 
gates of Sleep ${ }^{188}$ in Vergil (Aeneid, 6, 893-898), ${ }^{189}$ in which the Roman poet uses the old conception to indicate the time at

${ }^{188}$ Norden says on line 893: “'Tore der Traüme' (Somni portae, da oblique Casus von somnium unbrauchbar waren, vgl. Conington)". The editors have as a rule followed him. There is no inherent impossibility in such an interpretation: the poetical singular for the metrically inconvenient plural is no rare phenomenon (Norden's typography, however, is not in accord with his note; for he capitalizes the initial $S$ [Somni], which is surely impossible with his interpretation). Ribbeck (bracketing the whole passage) writes Somni. That can only mean-if referred to somnium at all-the personification of the true singular of somnium, which is inconsistent with all the other passages in Vergil, where the poet regularly conceives of many dreams, not one; so, e.g. in Aen. 6, 282-284, the dreams clustering beneath the elm are legion; furthermore umbris (894) and insomnia (896) would be very harsh in such close connection with Somni. To consider Somni the singular of the personified Somnus, Sleep, is simpler and open to no serious objection. Vergil, though admittedly writing under the influence of the Homeric tradition, nowhere held himself rigidly to one source (on the philosophic side, for example, cf. the numerous sources which he laid under contribution, cited by Norden in his introductory excursus, Die Quellenfrage, $20 \mathrm{ff}$.). Somnus as the marshaler of dreams, in Latin as in Greek literature, is a familiar figure. Ovid, Met. 11, 585 , gives the most elaborate picture, where Somnus is the father of a thousand dreams. The conception is Vergilian also: in Aen. 5 , $835 \mathrm{ff}$., Somnus comes in person to Palinurus 'bringing dreams of bale', somnia tristia portans (840). The passage as a whole (quoted below, footnote 189) has been the subject of much exegesis. Ribbeck, finding it inconsistent with $6,282-284$, where dreams hang bat-like beneath the leaves of an elm, secludes 893-896 (this inconsistency Ettig, Acheruntica, 354, 4 [cited by Hey, 16], denies) and changes eburna to Averna. The Heyne-Wagner excursus $\mathrm{xv}$ to Book 6, Norden's notes on 893-896 and his Einleitung, $47 \mathrm{f}$, and $\mathrm{Hey}, 16$, give the important literature and the plausible explanations.

${ }^{189}$ Aeneid, 6, 893-898:

Sunt geminae Somni portae; quarum altera fertur cornea, qua veris facilis datur exitus umbris; altera candenti perfecta nitens elephanto, sed falsa ad caelum mittunt insomnia manes. His ubi tum natum Anchises unaque Sibyllam prosequitur dictis, portaque emittit eburna. 
which Aeneas and the guiding Sibyl left the underworld, i. e. before midnight. ${ }^{190}$

The importance of all these to our study of the Homeric dream consists in the general acceptance of a country of dreams with a definite poetical situation and poetico-physical doors. By their imitations other poets bear witness to the vivid objectivity and personality with which Homer, to their minds, had portrayed the dream. This picture, once fastened upon poetry by its great originator (or adapter), maintained its commanding position and forced its conceptions upon poets who had long outgrown any naive belief in the source of dreams.

The few remaining passages in the Odyssey in which the dream is mentioned are of little importance, but are included here for completeness. In 20, 61-90 Penelope prays to Artemis to slay her. She complains that even the dreams which the gods send are evil (87), for that very night one like to Odysseus seemed to lie by her side, and she rejoiced, thinking it not a dream, ovvap, but a real vision, ü $\pi \alpha \rho(90) .{ }^{191}$ A woman here, as is the rule in the Odyssey, beholds the vision, but what specific god sends the likeness we do not learn. In 11, 207 Odysseus likens the spirit $(\psi \cup \times \dot{n})$ of his mother to a shadow $(\sigma \times i \tilde{n})^{192}$ or even a dream (oveipu); in 222 the mother's ghost tells him that the human

${ }^{190} \mathrm{Cf}$. supra, n. 38 ; but for other theories, stretching back to Macrobius, see the bibliography referred to in note 188, and add Granger, 44.

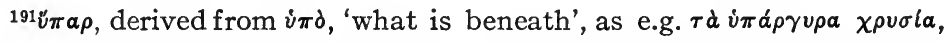
counterfeit gold coins, i.e. what is in reality silver (beneath), designates the real essence in contrast to the accidental, the transitory, perishable appearance or dream. $\delta \nu \alpha \rho, \delta \nu \epsilon \iota p o s$, are derived from $a \nu d$, 'oben auf', 'on the surface', 'apparent'. See Prellwitz. Boisacq does not accept positively the suggested derivations of Prellwitz, though he refers to his theory of the derivation of $u^{\pi} \pi \rho \rho$. See E. W. Fay, The Classical Quarterly, 11,212 , for a different view.

${ }^{192} \mathrm{Frazer}$, Belief in Immortality, 207, states that at Wagawaga, among the Massim in British New Guinea, the name for the spirit or soul of the dead person is arugo, the word used for a man's shadow or reflection in a glass or in water. This simile is an anthropological commonplace: see Spencer, Tylor, Rohde, for abundant references. 
spirit $(\psi \cup \times \dot{\eta})$ flies away like a dream from the charred body. ${ }^{193}$ In 19, 581 past joys are to be remembered in dreams. ${ }^{194}$

These shorter references are of little moment for the study of the economy of the plot or of the internal development of the dream device, but they throw light on the confusion which I have emphasized (supra, $35 \mathrm{ff}$.) as existing between the artistically primitive descriptions and the more advanced portrayals.

\section{Summary for the Homeric Poems}

In a rapid review of these passages, we find the poet of the Iliad experimenting in the use of the dream as a means of advancing the plot. He has no great familiarity with this device; hence he employs it only once. ${ }^{195}$ In addition, the loose structure of the Iliad demanded such frequent divine intervention for the practically independent incidents that the poet was forced back upon artifices with which, we may suppose, the poetry of the day was better acquainted,- waking visions, the physical appearing of present, living deities, and other divine machinery, frankly employed. Consequently the dream in this early form shows no complexity as a factor in advancing the narrative. It is elemental, straightforward, and directly applied. It does not work on the plot through an intangible emotion, as in the

${ }^{193}$ See Granger, 42. For the influence of the dream-image upon primitive and more advanced eschatology, see above, note 40 . Add Spencer (1906), 1, 185; 784; A. Lang, Book of Dreams and Ghosts, 109 (London, 1897); F. B. Jevons, An Introduction to the History of Religion, 43 (London, 1896).

${ }^{194}$ The idea here expressed closely approximates two modern conceptions of the dream: first, that which finds its psychical basis largely in memory (this theory is by no means new. Aristotle had formulated it: cf.

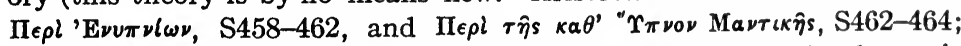
Büchsenchütz, 17 ff.); secondly, the theory of Freud that the dream is the fulfilment of a (suppressed) desire: see his third chapter, Der Traum ist eine Wunscherfüllung, 94-102. A closer approximation to the latter is found in Euripides, Iph. Taur. 44-46; see below, 95, n. 369. For Od. 24,12 see supra, 42 .

${ }^{195}$ Iliad, 2, 1 ff.; supra, 2-9. 
encouragement of Penelope in Odyssey, 4, 787-841, or prepare us for the developments of the plot by creating an atmosphere, as in Odyssey, 19, 509-581.196

With the Odyssey it is different. While the plot of the Iliad seems to be staged on Olympus, the plot of the Odyssey rests more largely on earth. And so it is easier, in the former, to show the gods acting; in the latter, it is easier to portray the means, less patently supernatural, through which the gods act. The dream is suited to fill this want and so the poet of the later work accepts the dream and develops it to meet this need. In the first place the dream is more frequently used to forward the action and with a quite noticeable advance upon the ruder pioneer work of the earlier poet. In the Odyssey the influence of the dream on the plot is, at times, more indirect and subtle; for example, in 4,787-841 the dream affects the action of the plot through the encouragement of Penelope. ${ }^{197}$ Or the influence may extend to a greater number of links in the chain of incidents which form the story, as in $6,13-51$, where the whole Phaeacian episode is made possible by Nausicaa's nocturnal vision. ${ }^{198}$ Or, again, it may simply strike the keynote, give the atmosphere, add a color-effect to prepare for what is to come, uses to which the earlier poet had not learned to put it..$^{199}$

In both poems the attitude of the poet toward the dream is one of respect and honor. He never debases it by employing it merely to add a petty prettiness, but always introduces it at a crisis. ${ }^{200}$

${ }^{196}$ Supra, 26 and 32 , respectively.

${ }^{197}$ Supra, 25-26.

${ }^{198}$ Supra, 29-30.

${ }^{199}$ Od. 19, 509-581; supra, 31-32.

${ }^{200}$ Supra, $8 ; 11 ; 25 ; 29 ; 31$. The mention of dream phenomena described on page 20 is an exception to this statement. This debasing was left for Euripides; at least we must so conclude from the evidence supplied by the extant literature. The introduction of a dream at the crisis became an unfailing convention for many non-Alexandrian writers, so that the turning point of an action was almost invariably 
In the Iliad Zeus is usually the divinity that sends the dream and he is generally regarded as its source by the persons of the

attended by the relation of a pertinent dream. Especially is this true of the writers of romantic (as opposed to pragmatic) history. Consider the following examples (from three writers of this class, a Greek, a Roman, and a Greco-Roman) of dreams at or preceding the crisis in personal or national fortunes: Herodotus, 1, 33-45, the dream of Croesus bereft of his son Atys; $107 \mathrm{ff}$., the dream of Astyages concerning Mandane; 209, of Cyrus immediately after crossing the Araxes, before his defeat and death at the hands of the Massagetae; 2, 139, 152, the dream of Sabaco, king of the Ethiopians, which led to his withdrawal from Egypt; 2, 141, the dream of Sethon before the successful battle with Sanacharibus, king of the Arabians and Assyrians; 3, 30, 65, the dream of Cambyses before he slew his brother Smerdis; 3, 124, the dream of the daughter of the Samian tyrant Polycrates before his departure for Magnesia and his death there; $5,55,56,62$, the dream in which Hipparchus was warned of his death at the hands of Harmodius and Aristogeiton; 6, 107, Hippias' dream before the battle of Marathon; 6, 131, the dream of Agarista, wife of Xanthippus, a few days before she gave birth to Pericles; $7,12-19,48$, the famous dream which, appearing to Xerxes and Artabanus, forced the momentous decision to invade Hellas (two other dreams are introduced, also, fittingly to mark this mighty crisis); 8,54 , Xerxes, at the height of his success, after the sacking of Athens and just before Salamis, repents of his sacrilege and sends the exiles back to the Acropolis to sacrifice as was their wont. Herodotus suspects that his action may have been prompted by a dream. Livy, 2,36, dream of Titus Latinius; $8,6,9-10$, dream of the consuls, Titus Manlius and Decius Mus, before the battle of Mount Vesuvius; 21, 22, Hannibal's encouraging dream before he crossed the Ebro; 25, 38, dream of Lucius Marcius which inspired him to save the armies after the defeat of the leaders, Publius and Cornelius Scipio; 26, 17, Scipio Africanus Maior, on setting out to retrieve the province of Spain, declares that his dreams portend success (feigning dreams for his guidance at important crises was one of Scipio's strongest holds upon the imagination of the people: 26, 19). Plutarch, Agesilaus, 6, dream of A. before his ill-fated expedition into Asia; Alcibiades, 39, dream of A. just before his tragic death; Alexander, 2, dream of Olympias, wife of Philip, bcfore Alexander's birth; 18, of Darius before he set out from Susa to meet Alexander; 24, at siege of Tyre, Alexander and the Tyrians dream pertinent dreams; 26, a dream directs Alexander to the site on which he was to build Alexandria; 41, dream of A. at a time of critical illness to his friend, Krateros; 50, dream of A. about Kleitos before A. ran him through the body in a brawl; Anto- 
story. ${ }^{201}$ Still, there is one case in which the dream is credited to Athene, ${ }^{202}$ and another in which the dream comes without reference being made to any deity who may be considered as

nius, 22, warned by a friend's dream, Octavius escapes from death at Philippi (cf. also, Brutus, 41; Dio Cass. 47, 41); Aristides, 11, in a dream Zeus points out the field at Plataea on which the battle should be fought; 19, death of Mardonius at Plataea foretold by a dream; Brutus, 20 , Cinna's dream before he was torn to pieces by the angered mob; 41 (cf. Ant. 22, above); Caesar, 32, allegorical, sexual dream before C. crossed the Rubicon (according to Suetonius, Caes. 7 and Dio Cass. 41, 24, this dream came to Caesar at Gades); 42, dream of Pompeius before Pharsalus (cf. Pomp. 68); 63, very elaborate tale of Calpurnia's dreams before the murder of Caesar; 68, Cinna's dream (cf. above, Brutus, 20); Cimon, 18, C.'s dream when all was ready for the expedition against Cyprus and Egypt during which he met his death; Cicero, 44, dream which attached C. to Octavianus (cf. Dio Cass. 45, 2, for a different version of the same dream; also, Suetonius, Aug. 94); Cleomenes, 7, C.'s dream before he abolished the ephors; Coriolanus, 24, dream of Titus Latinus (Livy, 2, 36, reads Latinius) when Rome was threatened by the Volscians; Crassus, 12, Onatius Aurelius' dream brings about the reconciliation of Crassus and Pompey (cf. Pompey, 23); Demetrius, 19, dream of Medius before the disaster which befell Antigonus; 29, dream of Demetrius before his defeat in battle; C. Gracchus, 1, dream of G. which forced him from retirement into public life and to his death (cf. Cicero, Div. 1, 26); Demosthenes, 29, dream of D., just before his death, about the tragic actor Archias; Eumenes, 6, E.'s dream before his decisive victory over Krateros (cf. also 13); Lucullus, 10, dream of Aristagoras when Cyzicus was in straits from the siege by Mithridates; 12, dream of Lucullus before his naval victory; Pelopidas, 20-22, dream of the leader of the Sacred Band of Thebans before the battle of Leuktra; Pericles, 3, dream of Agariste before the birth of her son Pericles; Pompeius, 23 (cf. above, Crassus, 12); 68, P.'s dream before Pharsalus; 73, dream of Peticius, shipmaster, before he received Pompey in distress; Pyrrhus, 11, dream of P. before capture of Beroea; 29, dream of P. before his failure at Sparta; Themistocles, 26, T.'s dream before his successful flight to Xerxes; 30 , a dream gives $T$. a warning which is responsible for his escape from assassination; Sulla, 9, S.'s dream when he was about to attack Rome, which was in the hands of the Marians; 28 , S.'s prophetic dream the night before a victorious contest with the Marians.

${ }^{201}$ Iliad, 1, 63; 2, 26.

${ }^{202}$ Iliad, 10, 496. 
having sent it. ${ }^{203} \mathrm{But}$ in the Odyssey, where the supreme divine direction of the plot (which in the Iliad is in the hands of Zeus) falls to the lot of Athene, this goddess is responsible for the majority of the dreams, ${ }^{204}$ although there is a very elaborate dream $^{205}$ which is not ascribed to any particular divinity. The receiver of the dream in the Iliad is in each case a male; ${ }^{206}$ in the Odyssey it is a woman. ${ }^{207}$ The latter conception becomes the usual convention for tragedy, though other departments of poetry show eclecticism. ${ }^{208}$

The two poems show five forms in which the dream appears. Of these, two are peculiar to the Iliad, two are restricted to the Odyssey, and one is common to both poems. Peculiar to the Iliad are (a) "Oveıрos or a dream daimon which the gods send to the sleeper, ${ }^{209}$ and (b) the ghost of the dead which appears in a dream. ${ }^{210}$ In the form common to both poems (c) an unsub-

${ }^{203}$ Iliad, 23, 62-107. This sending of dreams by the dead is characteristic of the only dream which is common to the three writers of tragedy, Aeschylus, Choe. 526 ff. (infra, 70-74); Sophocles, Electra, 417 ff. (infra, 79-84); Euripides, Orest. $616 \mathrm{ff}$. (infra, 102). The ghosts of the dead return to haunt or send dreams to plague those who have done them ill, even though the wrong was unintentional. Cf. the following references: Vergil, Aen. 4, 385; Horace, Epod. 5, 91; Tibullus, 1, 5, 51; 2, 6, 37; Propertius, 4, 7, 89; Ovid, Fasti, 3, 639; Ibis, 141; Plutarch, De Sera Num. Vind. 566c; Valerius Flaccus, 3,384 ; Statius, Theb. 3, 74; Diogenes Laertius, 8, 32; Ammianus Marcellinus, 14, 11, 17.

${ }^{204}$ Od. 4, 787-841; 6, 13-51.

${ }^{205}$ Od. 19, 535-581.

${ }^{206}$ Iliad, 2, 1-47; 10, 496; 23, 62-107.

${ }^{207}$ Od. 4, 787-841; 6, 13-51; 19, 535-581; 20, 87-90.

${ }^{208}$ The sending of the dream to the woman is, with one exception, the unbroken rule in tragedy wherever the dream is related in extenso. See my discussion, infra, 65, and except the charioteer's dream in the Rhesus. 10.

${ }^{209}$ Iliad, 2, 6-82, supra, 2-3; but cf. Od. 20, 87-90; Rohde, 1, 7; and Hey,

${ }^{210}$ Iliad, 23, 62-107; supra, 12-20. I distinguish, for this classification, the $\epsilon \ell \delta \omega \lambda o \nu$ of the dead from the phantom of a living person or of an immortal god such as I mention in (c). 
stantial wraith, phantom, $\varepsilon^{\prime} \delta \omega \lambda$ ov, appears. ${ }^{211}$ The two conceptions restricted to the Odyssey are (d) the dream in which the divinity in person comes to the sleeper in whom the god is interested, ${ }^{212}$ and (e) the dream in which neither men nor gods appear, but only things, and that too in an allegorical relation. ${ }^{213}$

The external origin and the objectivity of the major dreams in both poems I have frequently commented upon. ${ }^{214}$ The.first allegorical dream appears in the Odyssey, the evident product of a later technique. Yet even in this case the poet's lack of familiarity in the handling of the allegorical dream forces him to couple the interpretation with the allegory to soften the innovation. ${ }^{215}$

There are other evidences in the Odyssey of increased study and improved form. For example, in the conversation of Achilles with Patroclus' ghost, Iliad, 23, 62-107, there is the germ of a dialogue-dream; this germ a dream in the Odyssey presents in a later and more highly developed form in the longer dialogue of Penelope and Iphthime, 4, 787-841. This growing elaboration in the Odyssey affords striking confirmation of the later date commonly accepted for this poem. 26

A glance thus in review shows the dream-device in the making and indicates the wide range, in embryo at least, of the employment and the technique of the dream from which later writers could choose.

${ }^{211}$ Iliad, 10, 496-497, supra, 9-12; Od. 4, 787-841, supra, 24-27.

${ }^{212} \mathrm{Od} .6,13-51$, Athene.

${ }^{213} \mathrm{Od}$. 19, 535-581, supra, 30-34.

${ }^{214}$ Supra, 3, 10, 12, 22, 29.

${ }^{215}$ Supra, 34. 


\section{HESIOD}

Though much is said of sleep in Hesiod's poems, one would expect, a priori, from their undramatic nature, little resort to the dream-device. ${ }^{216}$ That expectation is confirmed; there is only one passage which is pertinent to a study of the dream. This passage is the prologue to the later poem, the Theogony. ${ }^{217}$ The discussion as to whether the appearance of the Muses here is a waking vision or a dream is as old as the day of the Emperor Marcus Aurelius and Fronto. ${ }^{218}$ Into that, however, we need not go. Suffice it to say that the Muses (whatever may be our decision as to the exact force of the tenses of $\dot{\varepsilon} \pi \varepsilon p \rho \dot{\omega} \sigma \alpha \nu \tau$ [8] and

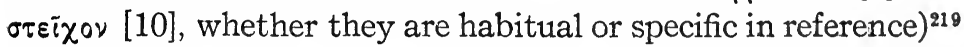

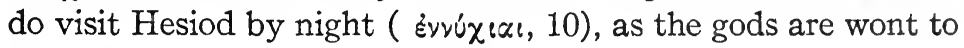

${ }^{216} \mathrm{Hesiod}$ really lies outside the scope of this present narrowly circumscribed study. I include him roughly among the writers of epic in accord with the definition of Aristotle. In my discussion of Hesiod I cite from the edition of Rzach, Leipzig, 1902. In the Theogony, 211-212, Night is the mother of Death, Sleep and the tribe of Dreams, $\phi \hat{v} \lambda o \nu$ ' $O \nu \in \ell \rho \omega \nu$; in 756, Hypnos and Thanatos are brothers, and in 758, the sons of black Night; in 762-766, the two brothers are contrasted, the one gentle to mortals, the other with a heart of bronze; in fr. 121 (157) we have $\mu a \lambda a x d s$ vinvos; in fr. 188, 3-4, sleep 'falls upon the eyelids'. These descriptions may be compared with my discussion of the same conceptions in Homer, supra, 36-42.

${ }^{217}$ For this decision about the chronology, compare the following note from Messer, 79: "Horum duorum carminum recentius esse Theogoniam inter omnes constat: cf. Dimitrijevic, Studia Hesiodea, 5-10; A. Meyer, De compositione Theogoniae Hesiodeae, Berol. 1887, 83; E. Lisco, Quaestiones Hesiodeae, Goett., 1903, 4-6; Rzach, Pauly-Wissowa, 8 (1913), 1178".

${ }^{218}$ Fronto, 1, 2. See Messer, 80. For this confusion of dream, vision and real appearance, cf. Vergil, Aen. 4, 222-278 and 4, 554-570, 7, $341 \mathrm{ff}$. and 7, 413-460; Plutarch, Brut. 36-37 and Valerius Maximus, 1, 7; Ovid, Met. 8, 453 and Diodorus Siculus, 4, 34, 6; Hey, 14.

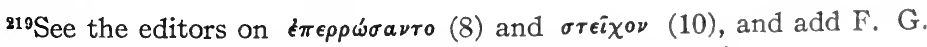
Welcker, Die Hesiodische Theogonie, 59 ff. (Elberfeld, 1865). 
visit bards ;20 they commune with him, and inspire him to song. But dream or waking vision, this passage is of supreme importance as the ancestor of many dream-prologues in ancient and mediaeval literature. ${ }^{221}$

The Muses have been dancing on Helicon (9); thence they make their way by night to the poet, who is 'tending his flock beneath divine Helicon' (23). They order him to compose a song and they give to him a branch of the bay tree, sacred to Apollo, as a symbol of his profession as a bard.

The Muses come to him of their own volition. The nearest approach here to the idea of a guiding divinity is in the presentation of a staff of Apollo's bay tree, but that gift would be a conventional gift from Apollo's choir to a poet, for the poet was under Apollo's protection.

This method of indicating the source of the poet's inspiration is a distinct advance upon the Homeric appeal to the Muses. The Homeric form of address is found in lines 104-115 of the Theogony. And so the prologue as a whole would seem to be an artistic compromise between an old form such as is found in Homer and a new form of the poet's own invention (or adoption). There may be many good reasons for believing this prologue (1-115) a hotch potch of successive recensions and interpolations by the early rhapsodists;222 but the existing contaminatio of two

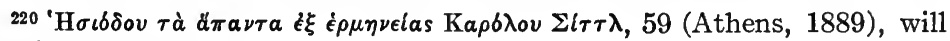
furnish parallels.

${ }^{221}$ Callimachus, Aitia, according to Anth. Pal. 7, 42 (see Messer, 81); Eratosthenes, Hermes (cf. Dilthey, De Callimachi Cydippa, Leipzig, 1863, 15); Alexander Aetolus, A pollo (Meineke, Analecta Alexandrina, xx, 59 and Dilthey, 1. c. 15, n. 4); Ennius, Annales, 1, iv-xi (cf. Vahlen, cxliv ff.); Propertius, 3, 3; Ovid, Amor. 3, 1-70; Fasti, 1, 99-282; 3, 167 ff.; 4, 193 ff.; 6,$9 ;$ Ex Ponto, 3, 3; 4, 4. For the mediaeval visions consult $M$. Dods, Forerunners of Dante, chap. 6, Mediaeval Legends (Edinburgh, 1903). The footnotes throughout this work are of exceptional value in tracing the development of the dream and the vision through the postclassical period and the Middle Ages, down to Dante.

${ }^{222} \mathrm{On}$ the composition and authorship of the prologue, see O. Gruppe, Die Griech. Kulte u. Mythen, 1, 599 ff.; Ellger, Die Zusatze zu dem Prooemium der Hesiod. Theogonie (Berlin, 1883); Fick, Hesiods Gedichte (Goett., 1887). 
types of introduction is no argument in support of that theory. To be sure, lines 104-115 are cast in an earlier artistic mould, but the practice of combining a primitive with a later poetical form found favor even as late as Ennius. ${ }^{223}$ If then, Ennius, a writer drawing his poetic inspiration from so many literary, bookish sources, could adopt and use in juxtaposition two forms for showing the divine authorization of his poem without feeling that there was anything incongruous in this combination, surely an equal liberty might safely be assumed for the earlier poet, Hesiod.

I have had occasion to treat at length, in another connection, the problems of this dream in the Theogony, tracing its line of descent in the literature, by a chain of exposition frankly based on mere inferences, down through the Greek and the Roman poets. I refer the reader to that discussion. ${ }^{224}$ For the present discussion the importance of this dream or vision is, not that it guides and controls the action-action the didactic poem has not-, but that it supplies the raison d' être of the whole production. For Homer appeals to the Muse to sing through him the wrath of Achilles or the many wanderings of Odysseus, but Hesiod is ordered by the Muses to sing for them. Not only will he be an inspired bard, but he will be a poet drawing his original command from deity.

${ }^{223} A n n .1$, I-xi (cf. Vahlen, cxlvi ff.). Cf. also the contamination of the primitive, direct dream with the allegorical dream, Od. 19, 535-581, supra, 34. My point here is that lines 104-115 cannot be secluded as spurious merely on the ground that the conception differs from that in the earlier part of the prologue.

${ }^{224}$ Messer, 78-92. 


\section{TRAGEDY}

As we turn from one department of literature to another we often find that the dream which is of the same type in essence may be so disguised in its superficial aspects by the limitations of the new genre that we have difficulty in identifying it in its new form. In tragedy the dramatic background, the change in the relations of the poet with his audience, the conventions of the different field, all force modifications which make it difficult, at times, to trace back to their archetype dreams having a common origin. In the epic we have the omnipresent, omniscient narrator, who can see not only through walls and doors, but through minds and hearts and motives, even those of deity and fate; he is present at and beholds every action and has entry to every public council and knows every secret thought of Olympus. From him the objective machinery of the dream is not concealed.

In didactic poetry the poet speaks in propria persona. He may claim that the Muses have inspired him; but after this original authorization he continues his teaching as a mortal having a greater or smaller measure of expert human knowledge of the subject in which he professes to instruct. In this department a wide play of the imagination, which is necessary for any extensive employment of so highly artificial a device as the dream, is lacking. This lack leads to an almost total absence of the dream.

In the department of tragedy the omniscient narrator and the didactic poet cannot appear as the reporters of the plot, and the story must be told and the action furthered by the living people involved in the toils of the plot. They cannot have the insight of the epic poet, who knows all happenings and all thoughts in heaven and among men. They cannot have the privilege of explaining to their audience the cause or the background of the story, as can the poet who speaks in his own person. The extent of the knowledge of each dramatis persona is limited, as 
is the knowledge of persons in real life, to the bounds demanded by verisimilitude.

The dream as it passes through the different departments of literature naturally assumes different accidental shapes. A dream daimon sent by Zeus will not often appear upon the stage. The objectivity, the personality of the dream must usually correspond to the experiences and the knowledge of the person represented by the actor on the stage. Deities will rarely be found telling the audience of their plans in respect to sending dream daimons, or intangible wraiths, or of coming themselves to appear to mortals. The dramatic poet must get his effects through a different medium, and this medium will govern and change the form of dreams in tragedy which are in essence the same as their prototypes in some other department. I desire to stress this point, for I am fully convinced that the different types of dreams employed in tragedy find their being in an imitation, more or less direct, of the dreams used by Homer. Freely as the dramatic poets handled the dream and much as they developed its content and its technique, the embryo of all the various forms is extant in the early epic.

Tragedy took over numerous motifs which already existed in the epos-anagnorisis, ${ }^{225}$ the deus ex machina, and a host of others. Among these were mantic and the dream. The dream exists in many cases in the $\mu \tilde{u} \theta 0 \mathrm{~s}$ which the epic tells, and so, when the narrative is dramatized, the tragic poet often adopts it. Or else the dream is imported by the tragic poet into the tale, which did not originally contain it, on the model of the dream in the epic. The point to be remembered is that the immediate source of the dream in tragedy is to be found not in religion and cult, but in the literature, that is, the source of the

${ }^{225}$ The origin of the anagnorisis of tragedy, P. Hoffmann, De Anagnorismo, 61-69 (Diss. Vrat. 1910): Unde Anagnorisis in Dramata Pervenerit, traces back through the lyric and the epic to the original mythos. Cf. also Staehlin, 35; 212-213. Much that Staehlin says here about mantic is equally applicable to the dream. 
dream in tragedy is a bookish, artistic source. ${ }^{225 a}$ This distinction holds throughout for Greek and Latin belles-lettres. For there is a gulf fixed-Aristophanes and the comedy in general form an exception ${ }^{226}$ - between the dream gods of the literature and the dream gods of the people, which is never spanned till the popularity of the dream cult forced the adoption of that cult by the priests of all the Olympian deities. The interaction between the two conceptions before that adoption seems to be practically negligible. ${ }^{227}$

${ }^{225 a}$ For the defense of this statement, see infra, n. 227.

${ }^{226}$ Comedy busied itself with a satire of contemporaneous beliefs and contemporaneous practices. Its function was to lampoon and correct the life which the audience knew. It could not limp behind that life. So one does not wonder that the popular equivalent of the dream which the tragic poets used for purposes of motivation, to wit, incubation, was ridiculed in comedy. The scene in the Plutus, $659 \mathrm{ff}$., in which this practice is so uproariously burlesqued should occasion no surprise.

${ }^{227}$ Incubation, Tempelschlaf, is the popular form in every day life of the literary motif which is here discussed. The works on incubation (i.e. the non-literary form of the divinely sent and the divinely acting dream) agree in holding that widespread practice of incubation was confined to the worship of Asclepius and of the allied Amphiaraus, Trophonius, Faunus, Podalirius, Calchas, Isis, Sarapis, and, in general, the chthonic divinities. Cf. Deubner and Hamilton, passim; Büchsenschütz, 35-37; Campbell, 227; 231; 368; Bouché-Leclercq, 2, 251; 269; 301; 3, 76; 275; 310; 380-381; Friedländer, Sittengeschichte Roms ${ }^{6}, 3,440$ ff.; De Marchi, 1, 238-239; Dill, 459-460; Maury, Magie, 231; 237-240; Dyer, 235-236; 242; 248; Gilbert, 251; Gomperz, Essays, 72. The artistic literature of the Greeks and the Romans shows no such preference. To the Greek examples which I cite in the text of this discussion, add the following divinities which appear in dreams or send dreams in Latin literature: Plautus, Jupiter, Aesculapius; Vergil, Great Mother, Apollo, Mercury, Jupiter, Somnus, Juno; Horace, Quirinus; Livy, Jupiter; Tibullus, Apollo; Propertius, Apollo; Ovid, Cupid, Venus, Jupiter, Pan, Faunus, Ceres, Somnus, Isis, Aesculapius; the Ociavia, the gods above (superos), 755; Petronius, Priapus, Neptune; Statius, Jupiter, Apollo, Mercury, Juno, Venus, Somnus; Valerius Flaccus, Jupiter, Somnus; Silius Italicus, Juno, Mercury, Somnus, Minerva, and the deified Virtus, Voluptas, Oenotria Tellus. My collections show indubitably that the belletristic dream divinities and those of the popular cult remained 
The dream is often unnecessary to the myth and hence the tragic writers, who handled the myths so freely, could have suppressed it had they so desired. But they found in it an artistic medium through which they could secure definite literary effects and not only adopted it when treating the epic legends in which it already existed, but often added it to those that did not contain it. For example, in the Persae, the story, though it has a historical background, pretends to no authenticity in its details. The dream was probably incorporated of choice by the author. ${ }^{228}$

Divination played in the tragedies the principal rôle, and was the main guide of the plot; the rôle of the dream was admittedly secondary. But the importance of the latter should not be underrated and is more often neglected and overlooked than too greatly emphasized.

almost entirely distinct. There is this reservation to be made, however: a time came when coincidence-even without interaction-could not be avoided. The divinities of the Roman Olympus of the decadence were so little differentiated theologically, their powers and their hierarchy so confused, that it is incredible that there corresponded to the invoked deity any precise conception of the activity which he was able to exercise. When, therefore, the popularity of the dream cult spread, the priests of all these divinities adopted dream-sending as a further activity of their gods. / Under these conditions all gods, even the exclusive circle of Olympus, became incubation gods. For this adoption of dream-sending by all the Olympian gods, cf. De Marchi, 1, 242; 285-289, and the following inscriptions quoted by him; CIL 6,520 , where Mercury is called Somniorum Iovis Nuntius; 8, 2632, Liber; 8, 4468, Saturn; 6, 663, Silvanus; 14, 2, Ceres and the Nymphs; 6, 288, Silvanus; 6, 367, Iuppiter Dolichenus; 3,1962 , Venus; 10, 1575-1576, Iupiter O. M. Dolichenus; 2, 5521, Mater Deum.

${ }^{228}$ O. F. Gruppe, Ariadne, Die Tragische Kunst der Griechen, 623 (Berlin, 1834): ". . . dann aber kann Phrynichus <i.e. in his Phoenissae> auch den Traum der Königin nicht gehabt haben, dieser aber scheint doch überhaupt das Vorkommen des Schattens erst zu motiviren. . . ." 


\section{AESCHYLUS}

LAeschylus, whose innovations in tragedy are well recognized, was probably the first dramatist successfully to employ the dream. Through its use he secures some of his most effective situations. He recognized, to some extent at least, as did Homer, ${ }^{229}$ the psychologic aspects of the dream. When, in $\mathrm{Ag}$. $420-426$, he speaks of the dreams aroused by Menelaus' longing for Helen, we must assume a knowledge on his part of the physical source of the dream that goes beyond the earlier explanation which bases the phenomena of the dream upon mere mental receptivity, passivity. ${ }^{230}$ But even here the terms are the terms used for the external dream $\left(\delta \delta \xi \dot{\alpha}_{l}, b \psi \iota \varsigma\right.$, as the lexicon shows). Still his artistic belief is, in general, pledged to that conception of the dream which represents its origin as from without, external to the mind of the dreamer. This artistic faith he accepted from the epic story together with the myths which he dramatized, 'slices from the great banquet of Homer', as he says in the account of Athenaeus. ${ }^{231}$

\section{The Persae}

In the extant plays of Aeschylus there are no indications of the growth of the dream from a less to a more artistic device.

${ }^{229}$ See the discussion of Iliad, 22, 199 and Od. 19, 535-581, supra, 20-22 and $30-35$, respectively.

${ }^{230}$ The primitive view is that the phenomena actually appear, and are not merely present to the mind of the dreamer. The persons whom he has beheld in sleep have stood in very truth before him. Such a theory presupposes no more mental activity than is required by the receptive function which it exercises for the sights and sounds which meet the waking mind.

${ }^{231}$ Athenaeus, $8,347 \mathrm{a}$ (see Christ, 1, $303 \mathrm{ff}$. for interpretation). The reader need not be reminded that I refer here not only to our extant epics, the Iliad and the Odyssey, but to the supplementary epics of the Trojan Cycle, to the epics of Thebes, and to the epics of Argos. Cf. Croiset, 185. 
In one of his earliest and most original dramas, ${ }^{232}$ the Persae (472 B. C.), he bursts upon us wit what I consider the most impressive dream known to literature, the dream of Atossa, mother of Xerxes (176 ff.). The play deals with what many regard as the most important episode in the history of the ancient world, the contest of Oriental despotism with Greek freedom, and the victory of the latter in the defeat of Xerxes. On this crisis in the life of the civilized world, Aeschylus, who had fought at Marathon and in all probability had seen the rout at Salamis, composes a drama and elects to guide the action of the plot by the introduction of a dream. The effect upon the audience of this dream, appearing, as it did, in a play which portrayed that great conflict, must have been stupendous.

The situation leading up to the episode of the dream and the story of the vision are as follows: Atossa (176 ff.) has been haunted by troublesome dreams ever since her son's departure for Greece. But in the night before the opening of the play a dream comes to her which excelled all the others in vividness. She tells it to the chorus. 'There seemed to appear before my sight two women, one in Persian, the other in Dorian attire, in size surpassing mortal women. Though sisters, they lived apart, one in Greece, the other in barbarian lands. ${ }^{233}$ They fell into a quarrel, whereupon Xerxes yoked them to his chariot.

232The Persae is the only tragedy upon a historical subject which has come down to us from the classical Greek period. In this, according to the notice of the ancient argument to the play, attributed to the grammarian Glaucus, Aeschylus was following the Phoenissae of Phrynichus (see Richter, 81). However, as Ribbeck (Über einige historische Dramen der Griechen, Rheinisches Museum, 30, 145) points out, no definite dividing line was drawn between myth and history, and the tendency was to look upon the tales which formed the subject of tragedy as historical, even if only remotely so. Cf. further M. Patin, $210 \mathrm{f}$.

${ }^{233}$ The aim of the poet was to bring to the minds of his auditors in the most impressive manner the political and historical significance of the struggle which had, temporarily at least, ended in the great national victories. The Persae was the second of a trilogy dealing with this mighty national conflict; cf. Christ, 1, 290. 
The Persian willingly bent to her task, but the Dorian plunged and broke the harness, dragged the chariot madly along, splintered the yoke, and threw Xerxes to the ground. As he fell, the figure of his dead father, Darius, stood beside him, commiserating him. On seeing Darius, Xerxes rent his clothes'. ${ }^{334}$

The queen mother's presaging fears of disaster to her absent son are increased, in the morning, as she is offering the customary sacrifices to the gods who avert the evils of the night, ${ }^{235}$ by the confirming omen of the attack of the hawk upon the eagle which flew for refuge to the altar of Apollo. ${ }^{236}$ The forebodings of ill from this omen prepare the minds of Atossa and the chorus

${ }^{234}$ Persae, 176-199.

235201-204. Purification after evil dreams or other horrors of the night is a practice to which onc finds constantly recurrent reference in both Greek and Latin literatures. The person thus visited by the chthonic divinities had suffered pollution by that contact (for, as I have stated frequently, the dream was looked upon as an objective thing). Certain rites of purification were to be performed in the bright light of day, corresponding to those which followed any sorrow, ill news or sickness. These rites took three forms: washing in running water, offering sacrifices to

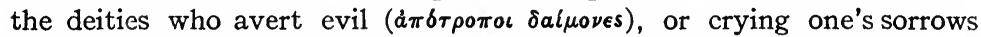
or visions to the sun; cf. the following passages: Sophocles, $E l .86,401,420$, 424, 427, 637 ff., 645; Euripides, El. 59; Iph. Taur. 42, 43; Med. 56 (compare the parody by Philemon, Athenaeus, 7, 288d); Aristophanes, Frogs, 1338 and scholium; Theophrastus, Char. 16, 11; Apollonius Rhodius, 4, 660-662; 668-669; Plautus, Mil. Glor. 394; Merc. 3-5; Ennius, Med., in Cicero, Tusc. Disp. 3, 26, 63; Vergil, Culex, 380; Aen. 3,147 ff.; 8, 68-69; Propertius, 3, 8, 11; 3, 10, 13; 4, 4, 24; Plutarch, De Superst. 166a; Persius, 2, 15-16; Statius, Theb. 9, 573; 601; Juvenal, 6, 522; Martial, 11, 50; Valerius Flaccus, 5, 332; the scholiast on Soph. Elec. 424: see infra, 80; 91.

236205-214. The use of the eagle and the hawk here may find its source in Penelope's dream about the eagle and the geese, Od. 19, 535-581, or in the dove and the hawk portent of Od.15,525 ff. In Od. 19 the allegorical, obscure part of the dream is interpreted by the eagle, which declared itself Odysseus (supra, $30 \mathrm{ff}$.); here the obscure visions of the night are confirmed by the omen. 
for the messenger of disaster who enters at line $249^{237}$ and tells the famous tale of Salamis and Xerxes' retreat. ${ }^{238}$ But the future is on the knees of the gods, and, since Darius appeared in the dream commiserating his son, his spirit may yet turn ill to good. So the chorus calls upon his soul to arise, and in answer to its libations and prayers the ghost of Darius appears (681 ff.). With warnings and explanations Darius bids Atossa prepare for the immediate return of Xerxes, and then descends beneath the earth (842). Xerxes enters at 907 and the play ends with an amoebaean lament between the Great King and the chorus over the disaster which has befallen the barbarian arms.

The importance of this dream for the unfolding of the story can be seen from this outline. As has been pointed out by the editors, ${ }^{239}$ it dominates the economy of the tragedy. It may not be the most beautiful dream in Greek literature, ${ }^{240}$ but certainly it is the most impelling. The artistic portrayal of the supreme crisis of classical history finds the chief source of its action in a dream. This is the more notable and the more important from the standpoint of technique when one recalls that the Persae is the earliest Greek tragedy which we can exactly date (472 B. C.), ${ }^{241}$ that it is the only extant Greek tragedy on a historical subject, ${ }^{242}$ and that the introduction of the dream motif was probably optional with the author. ${ }^{243}$ Such

${ }^{237}$ In lines 518-519 the queen expresses her realization of the fact that the dreain ?ad foretold the news of the messenger.

238353-471. The dream also motivates the appearance of Darius, a scene which that discriminating critic Richter, 99 , has rated so highly for dramatic effectiveness.

${ }^{239} \mathrm{Cf}$. Richter, 89 . See Wilamowitz's statement of the importance of this dream, Die Perser des Aischylos, Hermes, 32, 386.

${ }^{240}$ That palm goes to the dream in the Iph. Taur.; see infra, 91-96.

${ }^{241}$ Christ, 1, 290.

${ }^{242}$ Cf. supra, 61, n. 232.

${ }^{243}$ W. Nestle, Die Weltanschauung des Aischylos, Neue Jahrbücher für d. k. Alt. 19, 331, suggests that Aeschylus may have based his Persian material upon Dionysius of Miletus, one of the early logographers, who wrote $\Pi \epsilon \rho \sigma \iota k \dot{~ i n ~ t h e ~ I o n i c ~ d i a l e c t ~(C h r i s t, ~} 1,453$ ). There are only two short fragments of this work of Dionysius, however; so the evidence either way is unsatisfactory, as Nestle frankly admits. 
is the importance of the dream in its larger literary historical aspects.

For its influence on the plot of the Persae it finds its model in the dreams of Iliad $2,{ }^{244}$ and Odyssey $6 .{ }^{245}$ But the importance of the dream in the Persae as an essential element of the plot, the directing principle of the action, is much greater than in either of the two epics. The growth is natural enough. In the drama more than in any other literary genre all that is introduced must contribute to the plot; and so this epic germ it was the pleasure of tragedy to develop and to augment and to pass on to literary successors, until in the poems of a later period we often find the whole plot closely knit together by means of crossreferences, backward and forward, to the dream. ${ }^{246}$

The dream in the Persae belongs to the allegorical type, in this feature following Penelope's dream about the geese. ${ }^{247}$ But the symbolism is so patent as to be easily understood by the chorus of graybeards and by Atossa. ${ }^{248}$ It requires no Joseph. ${ }^{249}$ At the same time, it shows an advance in technique on the Homeric form of allegorical dream. It will be recalled that the epic poet, alarmed, perhaps, at the boldness of his innovation, enclosed within the limits of the allegorical dream its own interpretation. ${ }^{250}$ Aeschylus does not follow so primitive a plan, but he does make his figurative language so plain as to be unmistakable to an audience unfamiliar, we may assume, with

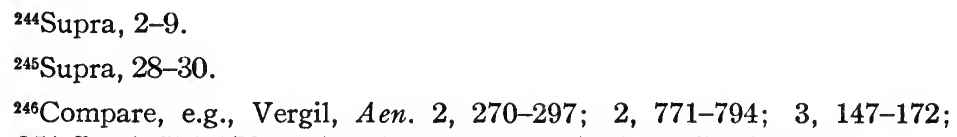

${ }^{249}$ Artemidorus, Onir. (ed. Hercher), 3, 18, has a ready explanation for such dreams, probably drawn from this passage; it is well known that Artemidorus was an admirer of Aeschylus. They indicate, he says, slavery, trouble and sickness, particularly if the dreamer is famous or of gentle breeding!

${ }^{250}$ Supra, 30. 
the allegorical dream in tragedy. For though the poet's representation of Europe and Asia under the form of women ${ }^{251}$ is the earliest use of this personification with which the extant literature acquaints us, nevertheless no one of the audience could fail to grasp the import of the figure. By this device Aeschylus wished to put vividly before the Athenians the magnitude and meaning of the struggle with the Persian. $\mathrm{He}$ could not afford to leave his meaning obscured. The content of the dream, hereafter, is for tragedy usually allegorical. ${ }^{252}$

The vision is sent to a woman, a practice already followed in the Odyssey and later conventionalized in Greek tragedy. ${ }^{253}$ It persisted long, appearing in numerous plays of the Renaissance. The sender of the dream is not mentioned, but the connection of the anxious ghost of Darius with the message of the dream may be noted. ${ }^{254}$ This appearance of the dead king in a dream also has its prototype in Homer. The starting point, as I have said above, ${ }^{254 a}$ for the appearance of the dead in dreams in European literature is the scene in Iliad $23,{ }^{255}$ in which the ghost of Patroclus appears to Achilles. But the situations are essentially different. Patroclus' ghost came to demand burial. ${ }^{256}$

${ }^{25}$ See the scholiast's comment on line 184 (O. Dähnhardt, Scholia in Aeschyli Persas, Leipzig, 1894).

${ }^{252}$ In Choe. 525-550, Clytaemestra dreams that she was delivered of a serpent; in Sophocles, Elect. $417 \mathrm{ff}$., she dreams that Agamemnon returns to earth and snatches from the hand of Aegisthus his scepter, which thereupon grows till the whole land of Mycenae is overshadowed; in Euripides, Iph. Taur. $42 \mathrm{ff}$., Iphigenia dreams of an earthquake that leaves standing but one pillar of her ancestral mansion, a pillar that symbolizes Orestes; in Hec. $90 \mathrm{ff}$., Hecuba dreams of the hind torn by the wolf; in Rhesus, 780-788, we have the charioteer's dream of the wolves and the horses of Rhesus.

${ }^{253}$ For the practice in the Odyssey, see pp. $27 \mathrm{ff}$.; for the convention in tragedy, cf. Staehlin, 171, n. 1; 215 and 215, n. 3.

${ }^{254} 184 \mathrm{ff}$.

254a Pages 12-13.

26523, 62-107.

${ }^{266} \mathrm{Cf}$. line 71. See infra, 75 . 
Darius was in need of no such rites. Hence the parallel between the two dreams lies entirely in the idea of the dead appearing in a dream. A much closer approximation to the Homeric situation is found in Pindar, Pyth. 4, 163, where Phrixus appears to Pelias and requests an $\alpha \nu \alpha$ ' $x \lambda \eta$ his soul, ${ }^{257}$ a request differing little from that of Patroclus.

\section{The Prometheus Vinctus}

In the Prometheus Vinctus the dream plays a secondary, but still highly important part in the economy of the tragedy by aiding in the motivation of the meeting of the hero and Io. A low estimate has been put upon this incident by some scholars, ${ }^{258}$ but such an estimate misses the whole point of the structure of the play and is based upon a wrong conception of Aeschylus' dramatic technique. He was, as Croiset well says, ${ }^{259}$ prone to introduce into his plays rôles of the second or even of the third order, not only to assist in the evolution of the plot, but also to emphasize the principal rôle and to aid in developing and in refining it. Particularly is this true in the Prometheus of the rôles of Hephaestus, Oceanus, the Oceanides, and Io. The incidents connected with these characters emphasize the rôle of Prometheus, and help us better to understand him. In the long Io episode, covering over 400 lines, ${ }^{260}$ the attitude of Prometheus to the immortals, the mainspring of the legend, and the indomitable will of this benefactor of mankind are depicted by the conversation of Prometheus and Io. In proportion as a

${ }^{257} \mathrm{As}$ I have noted above (notes 63 and 203; see the references there), the connection of the dead with the sending of dreams, spooks, spirits, is primitive and widespread. To these dead, as to the chthonic divinities in general, gifts were offered, to appease them, for the activities of the dead were universally looked upon as harmful, not as beneficent. The offerings were the toll of fear and not the promptings of affection.

${ }^{258}$ Richter, $56 \mathrm{ff}$., belittles it; Christ, 1, 295, misunderstands it; Weil, $33 \mathrm{ff}$., rescues it-and similar scenes-from the strictures of Richter.

268193.

${ }^{200}$ More than one third of the entire play. 
knowledge of these factors is necessary to the working out of the play, so indispensable will the device appear which brings this knowledge before the audience.

I give now a synopsis of the passage, to show the connection of the dream with the plot. Io, when driven forth by her father, Inachus, meets Prometheus (669 ff.). Her oft-repeated dreams (645 ff.) moved her father to consult Pytho and Dodona and it was in obedience to an oracle of Loxias that the saddened Inachus forced his daughter from her home. In the wanderings consequent upon the warnings of dream and oracle Io meets Prometheus, and the conversation which ensues reveals, more than any other single factor in the play, the character of Prometheus and his feelings toward his arch-enemy Zeus. ${ }^{261}$

The indefiniteness of dream messages and the uncertainties of dream interpretation contrasted with the comparatively greater clarity and definiteness of the oracle prevent the former from attaining an equal significance with the latter in relation to the plot. But one of its most frequently recurring functions is, as in Atossa's dream in the Persae $e^{262}$ or in Io's dream here, to prepare the way for an omen or an oracle upon which the action may be safely based. This combination of dream and omen or of dream and oracle is found nowhere in the Iliad or the Odyssey. Aeschylus, or whatever writers preceded him, ${ }^{263}$ has to this

261Weil, 33-35.

${ }^{262}$ Persae, $176 \mathrm{ff}$; supra, 60-66. In the Persae the portent has at least as great a degree of certainty as is usually predicated of the ambiguous oracle.

${ }^{263} \mathrm{I}$ am convinced of some partial interdependence, at least, between the dreams in the Prom. Vinc., the Persae, and Pindar, Pyth. 4, 163. The chronological relations of Aeschylus and Pindar are hard to establish. There is much in the literary activity of the one which parallels the literary activity of the other. Their paths in life would appear to have crossed frequently. The question is Gine of the priority of the Prometheus or of the fourth Pythian. Each shows a development and refinement of the type of dream found in the Persae. The question is: Was the dream of the $P . V$. modeled on that of the fourth Pythian, or did the latter appcar first? I have devoted some time to these interrelations, but have not yet reached any conclusions which seem to me wholly convincing. 
extent improved and added to the dream device. This change may have been brought about, partially at least, to conform to a more sophisticated view of the nature of the psychic processes involved; ${ }^{264}$ but, as I shall have occasion frequently to repeat, this factor is of small moment. The determining consideration was the developing and refining of literary devices which were already in use in other poetry. This change is natural in view of the different conditions in the dramatic vehicle. In the epic the god can be pictured fashioning and sending a dream phantom, a being whose message will compel immediate credence because its source is visibly shown to the reader. One can hardly expect a like method in tragedy. The story of the dream can come only from the lips of the dreamer, ${ }^{264 a}$ and this fact introduces that element of uncertainty about the vision (an uncertainty lacking in the epic) which must be confirmed by the direct omen. This latter has much of the immediate connection with deity which can be expressed in the body of the dream itself in the epic.

Io does not name the sender of the dreams nor does she tell the form in which the speaker addressed her. The reader might infer that Zeus, as the divinity interested, sent the visions of the night; but this is nowhere stated. ${ }^{265}$ Io merely tells us that dreams by night announce that Zeus desires her as a mistress

${ }^{264}$ Cf. P. V. 448-449; 485-486; Ag. $274 ; 491 ; 980-981$. These references recur frequently. Where the poet was talking out of his rôle, that is, where he was not composing an artistic dream (for the models of such a dream he would be dependent upon literary sources), but talking off-hand and permitting an unimportant side glance at the phenomena of the dream to creep in by way of illustration, he shows us that he had made fairly accurate observations of the apparent phenomena of dreams. To no such extent is a similar knowledge shown in the epic. The great defect in the work of Hey and others lies in the assumption that the poet's scientific explanations of dream phenomena in real life do not go beyond the evident theory of the dreams, which he employs for literary ends.

${ }^{264 a}$ For a more elaborate device see infra, $74 \mathrm{ff}$. and the notes there.

${ }^{285}$ The speaking oaks of Dodona address her as the bride of Zeus, 829835. 
and demand that she comply with the god's wishes (645 ff.). Harassed by their repeated visits she finally informs her sire about them, and he sends frequent messengers to Pytho and Dodona. But of the two it is the oracle of Loxias (669) which clearly interprets the dream, charging Inachus to thrust his daughter from her home and country, under threat of destruction to his whole family by the thunderbolt of Zeus if he does not obey. ${ }^{266}$ Hence one cannot assert from any information given in the text that Zeus sends the dream, since he permits the oracle of Apollo to interpret the vision, while Dodona refuses to divulge any information.

The epic dream is, as a rule, definitely assigned to some divinity, but it will be remembered that the single allegorical dream of Penelope was not, nor was the appearance of the ghost of Patroclus. ${ }^{267}$ Definite information as to the source of the dream in the tragedy will generally be lacking, a situation arising from the limitations of this department of literature, to which attention has been called above. ${ }^{268}$

The dream in the Prometheus is conceived in the epic form to the extent of being represented as external in origin, but it is not further personified. For in just what outward appearance the 'visions of the night' (645) visit Io she does not declare. But the message which they speak in lines 647-654 is such an address as would come from the lips of a daimon or a god or some $\varepsilon^{\prime \prime} \delta \omega \lambda . \mathrm{V}$ that heaven might fashion. It will be noticed that the dream is not allegorical in the sense that Penelope's dream about the geese is. ${ }^{269}$ There the prophecy of the future is told in symbols. Here the desire of Zeus and his orders to Io are explicit and are expressed without the use of tropes. The need of explanation

${ }^{266}$ For the account of the dreams and the questioning of the oracle, Acusilaus (a logographer of Argos [see Christ, 1, 453]) might have been used; cf. Nestle, 331 .

${ }^{267}$ For the power of the dead to send up dreams, see supra, nn. 62, 203, and 257 .

$26840-42$.

${ }^{269}$ Od. 535-581; supra, 30 . 
arises from two sources: first, the characters of the play are unable to believe the divine communication though it is of itself unambiguous; secondly, even if this credence were gained, the action ensuing upon it would not find favor with an unprepared audience. The poet must satisfy by some dramaturgic device familiar to his hearers the need for an explanation felt by the persons of the play or by his audience. The demand for oracular confirmation, then, comes from the source I have indicated, to wit, the department of literature in which the poet is writing. The consultation of the oracles and the reply of Apollo act as the dramaturgic substitute for the divine machinery which the epic poet is permitted to show to his hearers or readers. The epic poet can gain belief for his dream by portraying Zeus in the act of sending "Oveıpos to Agamemnon, ${ }^{270}$ Athene dispatching Iphthime to Penelope, ${ }^{271}$ or going in person (though disguised as the daughter of Dymas) to Nausicaa. ${ }^{272}$ To the dramatic poet this door is barred. He must gain entrance to his hearers' belief through some equivalent for the Homeric machinery with which they are familiar. This he finds in the confirming oracle or omen. We shall see Aeschylus solving this problem in different ways in other plays.

\section{The Choephori}

The Libation Bearers come to Agamemnon's tomb, sent to expiate a dream-terror ${ }^{273}$ which had visited Clytaemestra. Aeschylus' description in verses $32-36$ gives unearthly weirdness

${ }^{270}$ Iliad, 2, 1-47.

${ }^{271}$ Od. 4, 787-841.

${ }^{272}$ Od. $6,13-51$.

${ }^{273} \mathrm{Line} 32$. If one reads $\delta \rho \theta b \theta \rho \xi \xi \phi b \beta 0 s \kappa \tau \lambda$.; see Weil's Praefatio, LIII. If one reads $\Phi_{0 i \beta}$ os with $M$, which Wecklein (ed. Berlin, 1885) adopts, Apollo, instead of the murdered king, is the sender of the dream; but cf. 929. The reading $\phi \delta \beta$ os seems to be supported by the interpretation

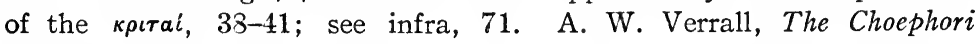
(London, 1893), reads poîßos and interprets it as a generic term, 'an inspiring power', suggesting that the poîsos of Delphi, the inspiring power of Delphi, was later identified with Apollo. Cf. Verrall's note on this passage and Appendix, 1, 2. 
to this dream-terror as it shrieks aloud in the depths of night from the women's quarters. In this description the poet would seem to wish to emphasize the external source of the dream, though the dream required interpretation. He shows us both sides of the shield: in these lines, 32-36, the features of the dream as it affects others appear; in lines $526 \mathrm{ff}$. we have the dream picture as Clytaemestra saw it. The arrival of the maidens at the tomb causes the discovery of the lock of hair and the footprints and the resultant recognition scene between Electra and Orestes. Orestes announces that he has come to avenge his father in answer to an oracle of Apollo. When he expresses his desire to know why the offerings are being sent to Agamemnon's tomb, Orestes learns the story of Clytaemestra's dream (526 ff.): she had dreamt that she was delivered of a serpent; when she gave it the breast, it drew in blood with her milk; thereupon Clytaemestra awoke from sleep, screaming.

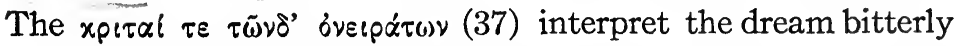
enough for the guilty woman, "that the dead beneath the earth were complaining against the slayers' $(38-41),{ }^{274}$ but they keep the interpretation to general terms and make no reference to Orestes as avenger..$^{275}$ The queen sends gifts to pacify the angry spirit of Agamemnon. When the chorus has finished the telling, Orestes immediately prays to earth and to his father's grave that the dream may be fulfilled in him. He then interprets the dream and applies it to himself: he is the serpent which Clytaemestra has suckled (540-549). He declares that he will be the slayer of his mother (549-550):

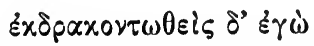

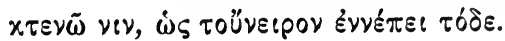

${ }^{274}$ That is, from the standpoint of the interpreters the dream was sent not by a god but by the murdered husband. Cf. supra, 70, n. 273.

${ }^{\mathbf{9 7 5}}$ Aeschylus may have intentionally suspended any more definite interpretation of the dream at this point so as not to weaken by anticipation the very artistic and highly effective passage where Orestes identifies himself with the serpent, 542-550. 
The chorus accepts his interpretation and promises him its aid (551 ff.). Clytaemestra also, when she finds her son determined upon her destruction, realizes that Orestes is the serpent of whom she had dreamed (928), and he confirms her fears.

The oracle of Loxias is the source of the main outline of the plot throughout the trilogy to which the Choephori belongs, and especially in this play ${ }^{276}$ maintains that headship as conductor of the action to which I have called attention above as one of the principal functions of the oracle in tragedy. ${ }^{276 a}$ The dream, here again, is less ambitious, but of closely secondary importance, as the foregoing synopsis shows. It sends forth the Libation Bearers to the tomb, causing the meeting of Electra and her brother and bringing about the famous anagnorisis, and in addition it strengthens Orestes in his determination to kill his mother.

This dream is very effectively employed to produce suspense. It is first mentioned in line 32 , but it is not told in detail till line 526. Its shadow is over the whole play. It enters among the earliest lines and is the last word on Clytaemestra's lips as her son takes her within to slay her (928). It blocks the tender appeal which the queen makes to the day when, a toothless child, Orestes was nursed at her breast (896 ff.). It gives an atmosphere of foreboding and foreshadowed disaster. In such auxiliary functions the dream is very significant.

In technique, this dream too is in the class with Penelope's dream in that it is allegorical and so requires interpretation to make its import clear to the audience. In the Persae the poet uses symbolism so patent as to require no Oedipus and, to guard further against misinterpretation, confirms its meaning by the omen of the hawk and the eagle. ${ }^{277}$ In the Prometheus the clear injunction of the oracle makes it impossible to apprehend wrongly the essence of the dream. ${ }^{278}$ Here the poet handles the interpretation with increased dexterity: first, the errand of the

${ }^{276} \mathrm{Cf}$. the references to the sources of the action in the oracle, $558-560$, $900,940,953,1029$.

$$
{ }^{276} \text { Supra, } 59 . \quad{ }^{277} \text { Supra, } 62 . \quad{ }^{278} \text { Supra, } 67 .
$$


chorus to the tomb suggests the intent of the dream; then the 'interpreters of dreams' hint broadly, but in general terms, that those beneath the earth (i. e. Agamemnon) are complaining (37 ff.); Orestes gives a full and confident interpretation (540 ff.); the chorus accepts his reading of the dream and piously prays that it may come to pass. ${ }^{279}$ The climax in this confirmation is reached when the queen realizes that Orestes has come as the serpent to slay her (928): o ' ' $\gamma \dot{\omega} \tau \varepsilon \times .0 \tilde{\sigma} \sigma \alpha \tau \delta$ ' $\delta^{\prime}$ ö $\phi เ \nu$ $\varepsilon \theta \rho \varepsilon \psi \alpha \dot{\mu} \mu \nu$, and the son replies (929-930):

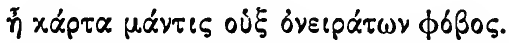

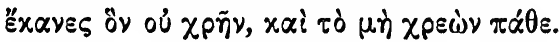

This handling of the interpretation far surpasses in refinement of workmanship that of any other dream in Aeschylus.

The introduction of the serpent is noteworthy. Stesichorus, according to a fragment of his Oresteia, preserved by Plutarch, ${ }^{280}$ had already introduced a serpent in a dream, but he had identified the serpent with the dead Agamemnon instead of with Orestes. In this version of Stesichorus we see the older conception that the serpent is the soul of the dead man. ${ }^{281}$ Staehlin ${ }^{282}$ thinks that Aeschylus has contaminated two primitive ideas: according to a widespread belief serpents drank milk and would draw nourishment even from the human breast;283 to this

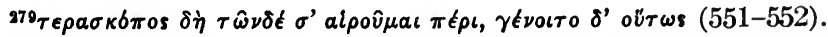

${ }^{280}$ De Sera Num. Vind. 10 (Bergk, 42). For the Greek of the Stesichorus fragment see infra, 83 .

${ }^{281}$ See Frazer, Adonis, Attis, and Osiris, 153 (London, 1907); Frazer, Pausanias, 3, 65 ff.; 5, 44-45; Frazer, Totemism and Exogamy (London, 1910), Index, s. v. Snake; Frazer, Golden Bough, Index, s. v. Snakes; Rohde, 1, 133; 1, 196; Jane E. Harrison, Prolegomena to the Study of Greek Religion, 217, 233, 301, 306, 326, 392, 418, 535 (London, 1903), and Journal of Hellenic Studies, 19, 204; 223; J. B. Deane, Worship of the Serpent, $245 \mathrm{ff}$. (London, 1830).

28236-37.

${ }^{283} \mathrm{He}$ cites Olbrich, Mitteilungen der Schlesischen Gesellschaft für Volks-

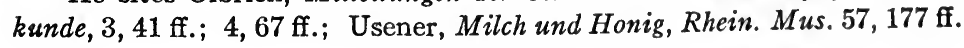


Aeschylus adds a vampire belief, already current in Eastern Europe, a belief in the existence of a being, generally supposed to be the soul of a dead man, which sucks by night the blood of living persons. ${ }^{284}$ In the Eumenides Apollo distinctly speaks of the vampire-like qualities of the Furies. ${ }^{285}$

The sender to whom we are to ascribe the dream in the Choephori is not mentioned specifically (unless we follow Wecklein and read, with the Codex Mediceus, $\Phi_{0 i} \beta_{0}$, in 32 ), but the inference is that the soul of the dead sent up the dream-the ancient view. ${ }^{286}$

\section{The Eumenides}

The boldest use of the dream device is in the Eumenides. ${ }^{287}$ There Aeschylus out-Homers Homer in emphasizing the objectivity of the dream. The Furies are disclosed asleep upon the stage and dreaming. Aeschylus has a living actor portray their dream. ${ }^{288}$ This actor enters in the rôle of the ghost of Clytaemestra and for forty-five lines ${ }^{289}$ addresses a rebuke to the sleeping Furies because they have allowed their ardor in the pursuit of Orestes to abate. This rebuke $i s$ the dream. The theatrical effectiveness of such a visual representation is selfevident. The extent to which this scene has been imitated confirms this feeling. It was copied by Euripides in his

284The belief in vampires is, at the present time, largely confined to Slavonic countries and those lands in which the Slav has settled-Russia, Poland, Servia, Albania, Greece and Slavonic Austria. The vampire is generally supposed to be the soul of a witch, or of a suicide, or of someone who has met a violent death (in this case the murdered Agamemnon).

$285183-184$.

${ }^{286}$ Sophocles, in the Electra, who borrows the dream from the Choephori, makes Electra declare pointedly that the dead Agamemnon sent the dream, 459-460; cf. also nn. 63, 203, 257 and 323.

$28794 \mathrm{ff}$.

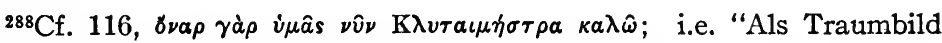
mahne ich euch, ich, Klytämnestra", Richter, 222.

28994-139. 
Hecuba, ${ }^{290}$ and in the tragedyOctavia ${ }^{291}$ written in the early Empire; on the contemporary stage it has had immense vogue. ${ }^{292}$ Its effectiveness on the stage explains sufficiently why Aeschylus chose to cast the dream in the external, objective form. One attempts, of course, to draw no conclusions from the type of dream here employed as to the poet's philosophic beliefs concerning the origin of dream phenomena.

In regard to artistic philosophical background the dream in the Eumenides belongs with the dream in which Patroclus appeared to Achilles :293 the return of the ghost of Clytaemestra to demand vengeance is of a type with the return of the soul of Patroclus, to demand burial. Both conceptions find their basis in folk-beliefs, ${ }^{294}$ but the artistic prototype of the dream in the Eumenides is the description of the return of Patroclus in the epic.

As a factor in outlining the plot of the Eumenides the dream assumes considerable importance. It is the propelling force behind the action of the Furies. While they sleep, they have let their prey escape them, spirited off by Apollo. The dream awakes them and sends them out again to overtake the matricide. One of the Sisters plainly states (155-161) that it is the ghost of Clytaemestra which arouses them again to pursue Orestes.

The necessity for this pursuit and the consequent importance of the dream which motivates it, Wilamowitz has shown. ${ }^{295} \mathrm{He}$

29053; 69-89.

201Incerti Octavia, 593-645 (ed. Peiper and Richter, Leipzig, 1902), the ghost of Agrippina appears to Poppaea, and this appearance the latter relates as her evil dream in lines 721-734.

${ }^{292}$ Sheridan's The Critic, Shaw's Fanny's First Play, the play within a play, are all essentially descendents, however remote, of this idea.

${ }^{293}$ Iliad, 23, 62-107; supra, 12-20.

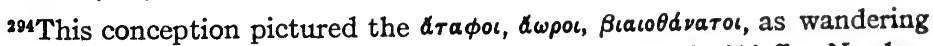
restlessly about this side of the Styx; cf. e.g. Rohde, 2, 411 ff.; Norden, in his Einleitung, 10-20. See also above nn. 44 and 50.

$295 \ddot{U}$ bersetzung der Eumeniden, 37 (in Staehlin, 39). 
finds in the Eumenides the union of two originally distinct legends: first, the purification of Orestes at Delphi through the medium of Apollo, and, secondly, the trial and judgment of Orestes at Athens. The value of the dream for the economy of the plot lies in the fact that it helps to explain the merging of these legends and the change of location of the ending of the play from Delphi to Athens. To Athens Apollo sends Orestes (79-84):

- . $\mu 0 \lambda \dot{\omega} \nu \delta \varepsilon \dot{\varepsilon} \Pi \alpha \lambda \lambda \alpha \dot{\delta} 0 \varsigma \pi 0 \tau i ் \pi \delta \lambda_{\iota \nu}$

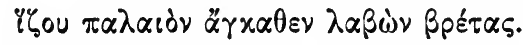

$x \dot{\alpha} x \varepsilon \tilde{\imath} \delta เ x \alpha \sigma \tau \dot{\alpha} \varsigma \tau \tilde{\omega} v \delta \varepsilon x \alpha i \theta \varepsilon \lambda x \tau \eta p i o u s$

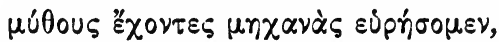

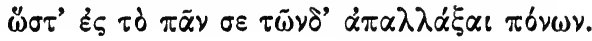

Thither in pursuit of him the Furies are sent by the dream, the ghost of Clytaemestra which will not let them rest at Delphi.

Here again a dead person appears in the dream. Indeed the connection of the dead with dreams throughout Aeschylus is noteworthy: compare the connection of Agamemnon with the dream in the Choephori, ${ }^{296}$ of Darius with the dream in the Persae, ${ }^{297}$ echoes, it seems, of the appearance of Patroclus in the Iliad, the earliest appearance, in the extant literature, of the dead in dreams. Clytaemestra also declares herself forced by the other dead to wander ( $95 \mathrm{ff}$.), as was Patroclus; ${ }^{298}$ as the ghost of Patroclus was the counterpart of the living hero, ${ }^{299}$ so she appears-calling attention to her wounds (102) - in form such as was hers when she lay dead at Orestes' feet. Unlike Patroclus, who did not know of the elaborate preparations to celebrate his funeral, she has knowledge of what has happened since her death, for, as she calls upon the Furies, while they groan and talk in their sleep ('like a dog dreaming of the

${ }^{296} 526 \mathrm{ff}$; supra, 70-74.

${ }^{298}$ Iliad, 23, 72-73; supra, 14.
${ }^{297} 176$ ff.; supra, 60-66.

${ }^{299}$ Supra, 13 f. Consult especially n. 42 . 
chase', says Clytaemestra [130 ff.]), ${ }^{300}$ she tells them that Orestes has escaped and fled $(111 ; 118-119)$.

Two concluding observations must be made. First, the dream is an exception to the allegorical type usual in tragedy; $; 01$ its message is direct and the Eumenides accept its rebuke (155). This fact takes it out of the category of Penelope's dream about the geese. ${ }^{302}$ Secondly, the dream is received by women, the feminine deities of revenge. ${ }^{303}$

\section{Minor References}

The shorter references in Aeschylus to dreams are, on the whole, unimportant, though some of them are picturesque and happy.

In the Septem, Eteocles the scoffer grants a late credence to the dreams which confirmed the curses of Oedipus (710-711):

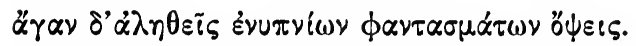

In the Supplices, when the herald attempts to carry off the

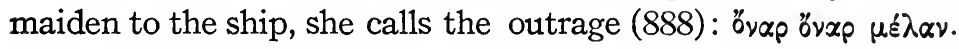
$\checkmark$ In the Prometheus, the hero declares that men, before his civilizing benefactions, having eyes saw not, having ears heard

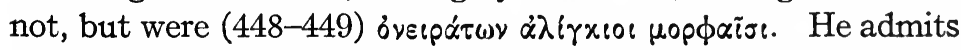
the need of interpreting dreams, and boasts himself the pioneer

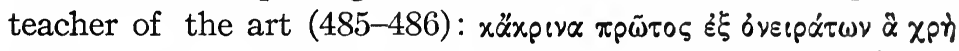
טँ $\pi \alpha \rho \varepsilon v \varepsilon \varepsilon \sigma \alpha$. The Oceanides liken feeble weakness to a dream

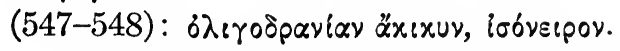

In the Agamemnon, the watchman speaks of his couch during

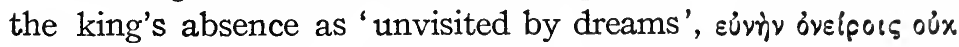

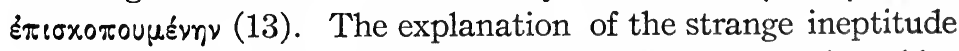
of the chorus to act at the crisis in 1343-1371 is foreshadowed by

${ }^{300} \mathrm{Cf}$. Lucretius, 4, $972 \mathrm{ff}$. (ed. Brieger):

venantumque canes in molli saepe quiete iactant crura tamen subito vocisque repente mittunt et crebro redducunt naribus auras, ut vestigia si teneant inventa ferarum, etc.

${ }^{301}$ See above, 33, n. 105.

${ }^{302} \mathrm{Od}$. 19, 535-581.

${ }^{303}$ Supra, 65, n. 253. 
the author early in the play: old age is as helpless as a child,

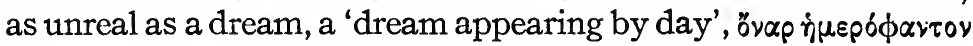
(82). In 179-180 there is indubitable reference to a dream state, as opposed to the treatment of the dream as external in

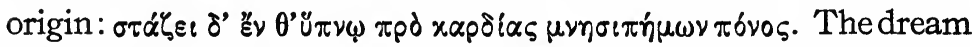

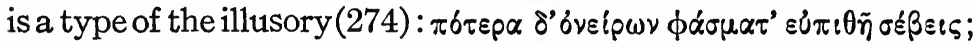
asks the chorus of Clytaemestra as she announces the fall of Troy. The queen accepts this description in her answer (275):

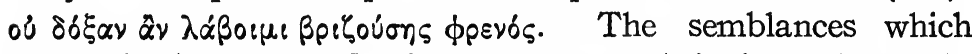
appear in dreams are fleeting, evanescent, bringing only a vain joy (420 ff.). The dream is used as the equivalent of 'untruth'

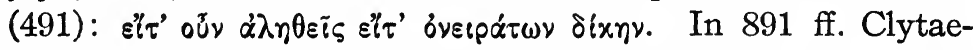
mestra, in her talk to Agamemnon, strikes a modern note. She recognizes that the common dream experiences cannot occur in the short time devoted to sleep. In 980-981, 'dark dreams' are

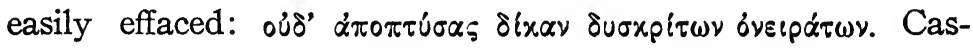
sandra in her vision of horrors (1214 ff.) sees the children of

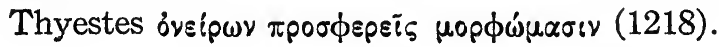




\section{SOPHOCLES}

$\angle$ Sophocles employs the dream device sparingly. There are in his extant plays but two lesser references to dreams and but one fully related dream. One of these smaller references is in the Oedipus Tyrannus, 980-982: to Jocasta the dream can at times be a satisfactory fulfilment of an unpleasant oracle. She comforts Oedipus with words to that tenor: $\sigma \dot{ } \delta^{\prime} \delta^{\prime} \varepsilon i s i d$

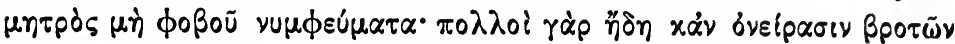

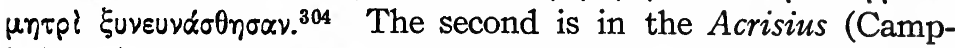
bell, 62) where fears are likened to winds which in the night the dreamer fancies he hears rising boisterously, but which he

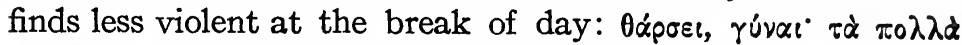

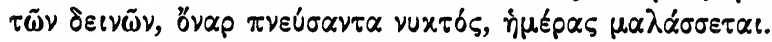

\section{The Electra}

$\angle$ This failure of Sophocles to use the dream device extensively could not have been other than deliberate.' For with the example of Aeschylus before him he might well have felt that a free handling of the myths would have permitted the introduction of the dream. There is only one important dream, however, in Sophocles' extant dramas. That is Clytaemestra's dream in the Electra. .05 / In introducing this motif Sophocles was, without doubt, following the lead of Stesichorus in the Oresteia fragment ${ }^{306}$ and that of Aeschylus in the Choephori. ${ }^{307}$ It is

${ }^{304}$ For examples of the type of dream to which Jocasta refers, cf. the dream of Hippias, Herodotus, 6, 17; the dream of Caesar when he was quaestor in Spain, Suetonius, Div. Iul. 7; Plutarch, Caes. 32; Dio Cass. 37,$52 ; 41,24$.

305417 ff., 480, 501, 644, 1390.

${ }^{306}$ Bergk, 42. See 73 and 83 , n. 280. For comment on the Oresteia of Stesichorus, cf. A. Müller, Aesthetischer Kommentar zu den Tragödien des Sophokles, 151 ff. (Paderborn, 1913). In this fragment the serpent is pictured as approaching with blood upon its head, $\beta \epsilon \beta \rho$ or $\omega \mu$ t vos (Clytaemestra had killed the king with an ax), and then being transformed into Agamemnon.

${ }^{807}$ Supra, 70-74. 
noteworthy that he introduces an entirely new version of the dream. In the Choephori Clytaemestra suckled a serpent which drew blood from her breast. ${ }^{308}$ In Sophocles' Electra the staff of Agamemnon sprouts and overshadows the whole of Mycenae. ${ }^{309}$

In the Electra Chrysothemis interrupts a dialogue about Orestes' return by entering with sepulchral offerings for Agamemnon, which her mother had sent her to make at his tomb (406). Clytaemestra has not told her the reason for the sending, but Chrysothemis thinks the cause 'an object of horror appearing by night' (410). As Electra presses her for a fuller explanation she gives the story of the dream, which someone had overheard as the queen related her dream to the sun $(417-425) .{ }^{310}$

If one compares this dream in its effect on the plot with the dream in the Choephori, he will find a notable difference. The latter was of great importance for the action of the play. In the Electra, on the other hand, the plot is independent of the dream. The vision brings Chrysothemis to the tomb, but she does not meet Orestes and the tokens which she has discovered there of his return are soon made to seem false when Electra maintains that he is dead (924-926). The dream produces no further effect on the progress of this episode than this bringing of Chrysothemis to the tomb. It plays, then, an entirely different rôle from that played by the Aeschylean dream. It is not surprising that this should be so: all the external machinery of

308533.

${ }^{309419-423 . ~ C f . ~ i n f r a, ~} 83$ and n. 318.

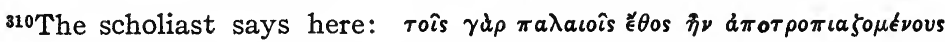

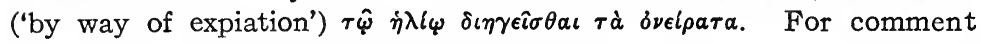
upon this and other customs usual after such a visitation of nocturnal spooks or dreams, see supra, 62 , n. 235 . Jebb, ad loc., suggests the following reasons for the address to the sun. Helios (1) is god of light and purity, $\dot{a} \gamma \nu \dot{\delta} s \in \sigma_{s}$ (Pindar, Olymp. 7, 60), who dispels the terrors of darkness; (2) he is the all-seeing god, $\pi a v b \pi \tau \eta s$, especially the detecter of guilt (cf. Od. 8, 270-271), and so able to reveal the lurking wrong which an evil dream might foreshadow; (3) generally he is a saving power, $\sigma \omega \tau \eta \dot{\rho}$ (Pausanias, 8, 31, 7; and cf. Sophocles, $E l .637 \mathrm{ff}$., where Helios and Apollo are identified). 
gods and oracles, the mechanism, in fine, by means of which the dramas of Aeschylus move, is kept more in the background by the greater craftsman, Sophocles.

What the dream does accomplish is in the realm of the portrayal of character. / It leads to the meeting of Chrysothemis and Electra as the former sets out for the tomb. This meeting gives the setting for that wonderful dialogue between the two sisters (892-1057) in which Sophocles displays his supreme ability to portray, with great strength and refinement, character by contrast. It causes the appearance of Clytaemestra on the stage at line 516.311 This entrance brings her face to face with Electra and there ensues one of the most important scenes in the play. In this scene is introduced a typical dramatic debate between mother and daughter, involving two long speeches, one for the defense (516-551), one for the plaintiff (558-609), and considerable attendant dialogue. The reader gets a more sympathetic insight into the queen's motives for the murder of Agamemnon and there is aroused that pity for her which is essential to make her part dramatic. The character of Electra, also, is illuminated from another angle and a different aspect of her indomitable determination is clearly portrayed.

This is exactly what one might expect. The reader feels that Sophocles accepted the dream which was part of the tale as it had been worked out by his two predecessors, Aeschylus and Stesichorus, and, having accepted it, took from it its important rôle of aiding in the development of the plot and made it perform a function more congenial to his artistic technique. We can illustrate this by noticing the point in the two dramas at which the dream enters. Sophocles mentions it late (417 ff.). In the Choephori, on the other hand, it is mentioned on the very threshold (32) and its influence is felt throughout the whole play. ${ }^{312}$

The problem which this dream presents to the dramatis personae is also deftly turned to the purposes of portraying

${ }^{311}$ She gives this information later, 634-636.

${ }^{312}$ Supra, 72. 
character. It is an allegorical dream. The audience, familiar with the main outline of the $\mu \tilde{0} \theta 0 \mathrm{~s}$, finds no difficulty with the meaning and interpretation of the dream. But the personae do not interpret and apply the dream with the same unerring confidence. The chorus hopes that it may foreshadow good for Electra and Orestes (479-481); indeed, the chorus is willing to stake its belief in oracles and dreams upon the favorable issue of this dream (499-501). But to Clytaemestra dreams are

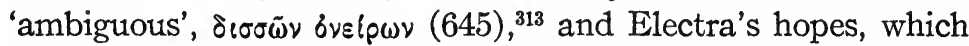
are at first aroused, are abandoned on the arrival of the message that Orestes is dead (673-674). The argument from silence on the part of the others indicates a like lack of any definite opinion as to the meaning of the dream. But some potency in its undoubted portent is realized throughout. Kaibel ${ }^{314}$ is certainly sound in his contention that Sophocles needed such an ambiguous dream to make possible the fine characterization of Clytaemestra in lines 634-659.

In massiveness the rugged, unambiguous dream of Aeschylus dwarfs this dream of Sophocles. ${ }^{315}$ The latter uses the dream with great delicacy and skill in his portraiture of character, but he does not make it play any large part in the development of the plot. One can see in Aeschylus the dream as part of the uncovered machinery of the plot guiding the course of the play; in Sophocles these divine agencies are as certainly assumed, but their mechanical operation is less patent. He accepts the epic view that the vengeance is justifiable. When that is once granted the plot moves on from its own internal forces. ${ }^{316}$

The details of the content of the dream are of interest. In the fragment from the Oresteia of Stesichorus the dragon approached Clytaemestra with gore upon its head (the blood which was upon

${ }^{313}$ For this interpretation, cf. G. Kaibel, Elektra, 172 (Lëipzig, 1896), and R. C. Jebb, 93-94.

${ }^{314}$ Loc. cit. 135.

315" "Der Traum ist dem Aischyleischen gegenüber (Choe. 526) dürftig", says Kaibel, 135.

${ }^{816} \mathrm{Jebb}, 32$. 
the head of Agamemnon from Clytaemestra's ax) and then was turned into Agamemnon. ${ }^{317}$

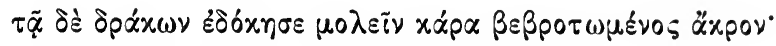

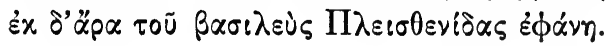

In Aeschylus, again a dragon appears: it draws blood from the breast of Clytaemestra. The dragon here symbolizes Orestes. Both these conceptions have a basis in folk-lore in the widespread cult of the serpent, a cult which has had various ramifications. ${ }^{317 a}$ Sophocles turned from the serpent type, which after all has something of the gruesome and the abhorrent, to an equally familiar folk-legend of the sprouting staff ${ }^{318}$ - a type of legend certainly not employed for the first time in the story of the rod of Aaron. Herodotus used the same type of dream: Astyages dreamt that there grew from the womb of his daughter Mandane a vine which overshadowed the whole of Asia. ${ }^{319}$ The vine was Cyrus. Sophocles was perhaps moved to this choice by the two passages in Homer dealing with the sceptre of Agamemnon, Iliad, 1, 234-239; 2, 101-108. Particularly happy does this choice seem, especially to moderns familiar with the use to which Lessing in his Laokoon put the pertinent passages. ${ }^{320}$ Without doubt its connotative force would be even more pregnant to the Greeks, to whom Homer was as well

317The prototype in literature of this transformation is that of the eagle into Odysseus in Penelope's dream, Od. 19, 535-581; supra, 30-35. For further comment cf. supra, 73.

${ }^{317 a}$ See supra, n. 281.

${ }^{318}$ For bibliography, covering a large number of monographs and references which treat the different aspects of this folk-legend, see Staehlin, 51-53, and footnotes there.

${ }^{319}$ Herodotus, 1,108 . See also, for the idea of the spreading branches, the dream of Xerxes, Herodetus, 7, 19.

${ }^{320}$ Laokoon, xv: "Was bekümmert sich aber Homer, wie weit er den Maler hinter sich lässt? Statt einer Abbildung giebt er uns die Geschichte des Scepters: erst ist es unter der Arbeit des Vulkans; nun bemerkt es die Würde Merkurs; nun ist er der Commandostab des kriegerischen Pelops". 
known as the King James version is to the Scottish member of a free kirk. ${ }^{321}$

Here, as in the earlier passages in which the dead appear in dreams, ${ }^{322}$ it is noticeable that there is no direct reference to any deity as the sender of the dream. To a great degree the ghost seems to return of its own accord (459-460). ${ }^{323}$ It might seem that Apollo's interest in the message of the dream is indicated by Electra's appeal to him 'to bring its fulfilment, if good; if bad, to allow it to recoil upon her foes' (644-647). The dream is half direct-Agamemnon appears as does Patroclus, an incident which requires no interpretation; half symbolical, in the sprouting staff, a wonder which is allegorical as are the geese in Penelope's dream. But the importance of the dream lies in its allegory, and the little of the non-symbolic which is left clinging to it in the form of the ghost of Agamemnon is perhaps a survival from the combination of the allegorical and the direct elements, which I have discussed, in the Odysseus of Penelope's dream. ${ }^{324}$ In being allegorical it follows the usual-but by no means unbroken-convention of tragedy, as it does also in appearing to a woman..$^{325}$

${ }^{321} \mathrm{Kaibel}, 137$, thinks that the passage in the Iliad $(1,234)$ where Achilles takes oath by his scepter which would never bloom again may have influenced Sophocles in the figure which he adopted.

${ }^{322}$ Od. 19, 535-581; Stesichorus, Oresteia (Bergk, 42); Pindar, Pyth. 4, 163; Persae, $176 \mathrm{ff.;}$ Eumenides, $94 \mathrm{ff}$.

${ }^{323}$ I have noted above, $20, \mathrm{n} .63$, how the dead seem to share with the chthonic divinities (and naturally so) the power of sending dreams. Cf. also n. 286.

${ }^{324}$ Supra, 34-35.

${ }^{325}$ Supra, 28, n. $83 ; 51$, n. 208; 61. For allegorical dreams, cf. 33, n. 105. 


\section{EURIPIDES}

Though there are four important dreams in the tragedies of Aeschylus, there is, as has been shown above (p. 79), but one in the works of Sophocles. Euripides, who, as is well known, carried on the Aeschylean tradition, ${ }^{326}$ shows two that are of larger import, one of lesser, and fairly frequent references to dreams or dream phenomena.

\section{The Hecuba}

In the Hecuba ${ }^{327}$ Euripides adopts the device which Aeschylus

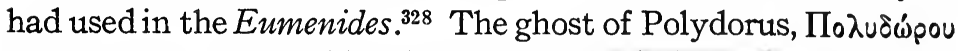

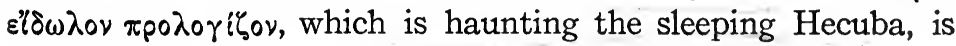
portrayed visibly on the stage before the eyes of the spectators (1-58). The ghost tells the audience how he had been sent by Priam to Polymestor for safe-keeping over against the fall of Troy (1-20); he describes his treacherous murder at the hands of Polymestor (21-27): he declares that his body had been left ¿ँ $\tau \alpha \circ \circ \varsigma(30)^{329}$ and floating about the sea, and that at this very moment he was gliding about his dear mother's head (i. e.

${ }^{326}$ For the general question of how Euripides carried on the Aeschylean tradition in vocabulary, meter, construction of plot and, in fact, in the whole matter of literary technique, see the doctoral dissertations of O. Krausse, De Euripide Aeschyli Instauratore (Iena, 1905); H. Burkhardt, Die Archaismen des Euripides (Hannover, 1906); and the bibliography cited in their footnotes. A still more recent essay is that by C. A. Manning, A Study of Archaism in Euripides (New York, 1916); see especially pages $68-72$.

${ }^{327}$ For a recent discussion of the technique of this prologue cf. E. Petersen, Die Attische Tragödie (Bonn, 1915).

328 Supra, 74-77.

${ }^{32}{ }^{\circ}$ For the folk-belief in regard to the $\alpha r a \phi o l$ cf. Rohde, $2,411 \mathrm{ff}$.; Norden (Einleitung), 10-20. See also n. 294. 
he was appearing to her in a dream), ${ }^{330}$ having hovered over the body three days (32), ${ }^{331}$ while the Greek ships were delayed through the appearance of the ghost of Achilles above his tomb demanding Polyxena as a victim $(35-41) ; 332$ he prophesies the death of his sister in answer to Achilles' demand (42-44), and the finding and burial of his own corpse (45-52); then he says $(52-54)$ :

$$
\begin{aligned}
& \text {. . } \gamma \varepsilon p \alpha i \tilde{\alpha} \delta^{\prime} \varepsilon \dot{x} \pi 0 \delta \dot{\omega} \nu \chi \omega p \eta \hat{\sigma} \sigma o \mu \alpha \iota
\end{aligned}
$$

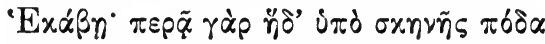

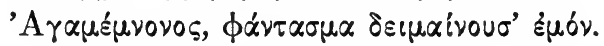

Finally after a few further lines of soliloquy the spectre is gone.

Hecuba now comes upon the scene, driven from Agamemnon's tent by disquieting dreams (68-97) concerning Polydorus and Polyxena.

$$
\tilde{\omega} \sigma \tau \varepsilon \rho \circ \pi \dot{\alpha} \Delta เ \delta \zeta, \quad \tilde{\omega} \sigma x \circ \tau\{\alpha \text { vú } \xi \text {, }
$$

she says as she sees the starry heavens, which make the night seem all the darker; ${ }^{333}$ she invokes earth, the chthonic divinities; ${ }^{334}$ she calls aloud for Helenus or Cassandra to interpret the dreams which she has had about her son and daughter. She distinctly uses the plural, bveipous (89), yet in what follows she narrates to the chorus but one dream, the dream of the hind and the wolf (which manifestly refers to Polyxena), for the apparition of Achilles, which she mentions (92 ff.), came not to her personally, but to all the Greek host, and was not a dream, but a

${ }^{230}$ This is the interpretation accepted by Bernardakis, ad loc. $\mathrm{He}$

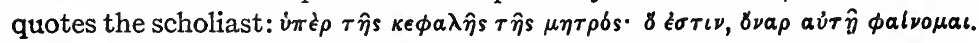
Cf. Iliad, 2, 20; 23, 68; Od. 4, 803, etc., and Weil, Sept Trag. 219.

${ }^{331}$ Three days was the usual period for the soul to linger about the corpse; cf. Bernardakis on this line.

${ }^{332}$ The appearance of Achilles is not a dream but a waking vision; cf. infra, 87, n. 335 .

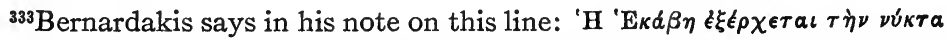

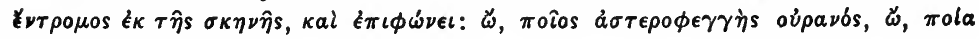

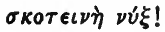

${ }^{334}$ Again the interpretation of Bernardakis. 
waking vision. ${ }^{335}$ What then was her vision of Polydorus? The answer is: the pertinent parts of the prologue which the ghost of Polydorus speaks. With consummate skill Euripides does not have Hecuba repeat what he has already portrayed upon the stage: the dream of Hecuba about Polydorus has been put before the audience by the ghost of Polydorus. Hecuba tells the chorus the vision which can be applied only to Polyxena. The proof of the correctness of this interpretation we may see by comparing with this dream prologue the passage (702 ff.), wherein Hecuba is shown the dead body of her son:

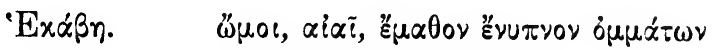

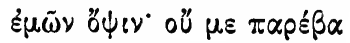

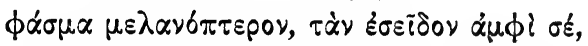

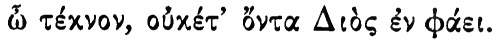

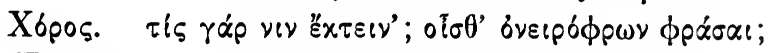

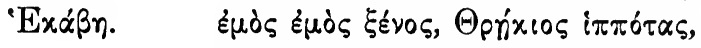

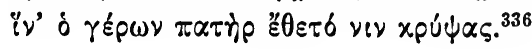

That the ghost which speaks the prologue is the dream has not always been understood by the editors, and no less a critic than Wilamowitz has gone so far as to declare lines 73-78 and 90-97 the work of an unskilled interpolator. ${ }^{337}$ Nothing could be further from the truth. To be sure there is not 'complete coextension' between what the ghost says to the audience ${ }^{338}$ and what Hecuba sees in the dream. For example, there is no need for telling Hecuba the well-known tale of Polydorus' being sent

${ }^{335}$ In the poets the waking vision may be seen by several, as here by all the Greek host, but in the dream the spirit commonly appeared to a single person; cf. Hardie, Lectures, 91.

336702-720.

${ }^{337}$ Hermes, 44, 446-449. He feels that this prologue is a combination of many variant archetypes thrown together by the Alexandrian scholars into a conglomerate mass for fear that something might be lost in the attempt to excise what was not genuine.

s381-58. 
to Thrace. But that Euripides conceives Polydorus as appear-

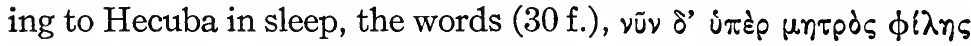

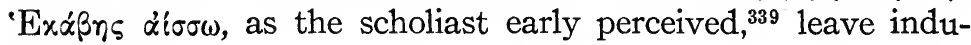
bitable.

The situation which seems to have caused this lack of entire coincidence is the following. Aeschylus in his Persae, it will be recalled, had introduced the ghost of Darius, ${ }^{340}$ frankly, admittedly a ghost, talking to the waking Persians, not a dream. In his Eumenides, he portrayed the ghost of Clytaemestra on the stage. The appearance and words of Clytaemestra were the Eumenides' dream, for all that Clytaemestra says is addressed to the sleeping Furies and is easily understood as the content of their vision. There are no words intended for the ear of the audience alone. Euripides, notoriously fond of Aeschylean devices, ${ }^{341}$ has been guilty of a contaminatio of these two conceptions. He has united the idea of the ghost of the dead speaking in a waking vision (from the Persae) and that of the ghost of the dead appearing and speaking in a dream (from the Eumenides). The situation is further complicated because he brings this dream to the forefront of the drama and uses it

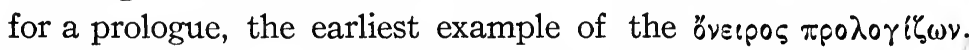
The very heavy share of the burden of advancing the plot put upon the dream in this position has led to some infelicities and some illogicalities, due to the fact that the author is handling an unfamiliar bit of technique. ${ }^{342}$ Strictly, all that can be intended only for the audience rather than for the worried Hecuba should have been excised from this dream, as Aeschylus was careful to do in the Eumenides. But in spite of these strictures, we must see that the prologue remains of one texture, technically, with Clytaemestra's dream in the Eumenides.

${ }^{839} \mathrm{Cf}$. the statement of the scholiast, quoted in n. 330 .

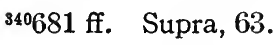
${ }^{341}$ Supra, 85, n. 326.

${ }^{342}$ The infelicities Wilamowitz, Hermes, 44, 446 f., has, perhaps, overemphasized. 
In regard to the economy of the play this dream has even a heavier duty to perform than the usual Euripidean prologue. ${ }^{343}$ The subject of the play is the psychology of Hecuba under the lash of sorrow and revenge. ${ }^{344}$ This psychology is depicted by the joining of two incidents, which have no inner connection or necessary relation, the sacrifice of Polyxena and the discovery and punishment of the crime of Polymestor. ${ }^{345}$ This joining is effected, so far as the incidents can be joined, by the dream prologue..$^{346}$ It is emphasized again by Hecuba, at her first entrance $(73-76)$ :

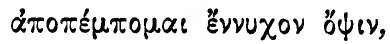

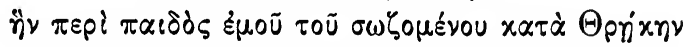

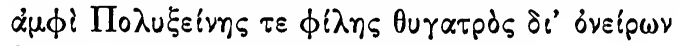

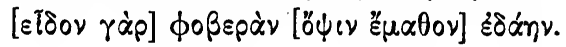

and then, as if to introduce the second incident, the poet makes the following the last words which pass between Polyxena and her mother as the daughter is led away for immolation (428-430):

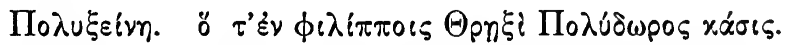

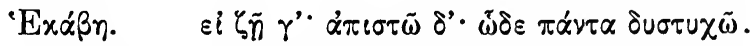

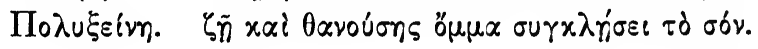

The chorus sings a lyric, after which Talthybius enters and the Polydorus-Polymestor episode begins.

${ }^{343}$ The greatest changes in the external form of the drama made by Euripides were (1) in the prologue, and (2) in the use of the deus ex machina, i.è. the epilogue. Cf. P. Masqueray, Euripide et ses idées, 39-45 (Paris, 1908); F. Commer, De Prologorum Euripideorum Caussa ac Ratione (Diss. Bonn., 1864); also the ridicule to which Aristophanes subjects them, Frogs, 1198-1247. For a defense of the deus ex machina see H. H. Yeames, The Classical Weekly, 10, 202.

${ }^{344}$ The lines $422-423$, seemingly so colorless, could really be taken as the text of the play, "das ergreifende Pathos der unglücklichen Königin", says Christ ${ }^{2}, 1,273$.

${ }^{345} 1-52$.

${ }^{346}$ See Wilamowitz, 1. c. 446; Staehlin, 89-90. 
This dream does not control any long succession of incidents as dreams do elsewhere. It does indeed bring Hecuba from the tent to cry her dreams to heaven, ${ }^{347}$ but beyond that it does not affect the action. In this point of technique Euripides here differs signally from Aeschylus, who employed dreams so freely as part of the machinery of the plot. The aim of this play of Euripides primarily was to depict human psychology and not to portray human action. The function of the dream lay, then, in a different dimension and in this dimension, as I have indicated in the preceding paragraph, it carried successfully an important burden.

Turning now to details, we find that many of the stereotyped features which I have hitherto noticed are present. The $\varepsilon(\delta \omega \lambda$ ) of Polydorus takes the traditional position of the dream of Homer (30), i $\pi \dot{\varepsilon} \rho \mu \eta \tau p \dot{s} \phi \hat{\imath \lambda \eta \varsigma^{348}}$ Its epic prototype is the returned Patroclus of the Iliad; to this are added tragic refinements taken from the poet's predecessors, particularly Aeschylus. Polydorus comes, as do Patroclus ${ }^{349}$ and Clytaemestra, ${ }^{350}$ because something prevents his spirit from resting in peace. Like Patroclus, ${ }^{351}$ Polydorus has prophetic sight. ${ }^{352}$ The part of the dream which deals with Polydorus is epically direct and unallegorical..$^{353}$ The portion dealing with Polyxena is allegorical; the symbolism, which involves a dappled hind and blood-marked wolf, is drawn from the animal world (90-91). Again a woman is the recipient..$^{354} \mathrm{X} \theta \omega \nu^{355}$ is definitely mentioned as the sender. Finally, as coming from the earth, dreams are black winged $(71 ; 705) .{ }^{356}$

${ }^{347}$ Consult the discussion of purification after dreams, supra, 62, n. 235. ${ }^{348} \mathrm{Cf}$. Iliad, 2,$20 ; 10,496 ; 23,68 ;$ Od. 4,$803 ; 6,21 ; 20,32$; supra, 6 , n. 22.
${ }^{349}$ Iliad, 23, 71.
${ }^{350}$ Eumenides, $97 \mathrm{ff}$.
${ }^{351}$ Iliad, 23, 80-81.
${ }^{352}$ Lines $42-52$.

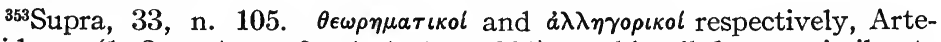
midorus $(1,2$, p. $4 ;$ p. $9 ; 4,1,1$, p. 201) would call dreams similar to these. The Polyxena section he would class with the a $\lambda \lambda \eta \eta \gamma o p \iota k o l$.

${ }^{354}$ Supra, nn. 81. and 83.

${ }^{355}$ Cf. Iph. Taur. 1262.

${ }^{356} \mathrm{Cf}$. Od. 24, 12; Aeneid, 6, 283. 


\section{The Iphigenia Taurica}

The second dream which bulks large in Euripides is in the Tauric Iphigenia (42 ff.). Iphigenia dreamt that she was sleeping once more in her native Argos when suddenly an earthquake drove her in terror from the house. Stopping without she looked back and beheld the palace thrown down in ruins, so that but one pillar was left standing. This pillar received the golden ${ }^{357}$ locks and voice of a mortal. She, weeping, sprinkled this mortal as a victim for slaughter.

In this play, as elsewhere in tragedy, ${ }^{358}$ the oracle of Phoebus is the mainspring of the action (77 ff.). But Euripides, probably writing under an evergrowing Aeschylean influence, ${ }^{359}$ promotes the dream to the Aeschylean rôle of aiding in situation and incident. Recognizing, then, that the oracle is the foundation of the action, we must nevertheless notice that the dream lends no meager assistance to the progression of the plot. Iphigenia, brought upon the stage by it to tell her vision to the sky, ${ }^{360}$ sketches the historical background and setting of the play (1-41). ${ }^{361}$ She then tells her dream and fastens upon it a wholly unnecessary and, as the sequel shows, a false interpretation. ${ }^{362}$ 'Orestes is dead' $(55-58)$ :

${ }^{367}$ Euripides is careful to help to the understanding of his allegory by hints: $\xi a \nu \theta d s$ is a word that he generally uses to describe the hair of the members of the house of Atreus.

${ }^{368} \mathrm{Cf}$. supra, 59.

${ }^{859}$ Supra, 88, and nn. 326 and 341 .

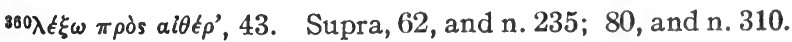

${ }^{361}$ Verses 1-41 comprise the usual Euripidean narrative prologue. Our author uses such prologues to all his plays except the Iphigenia in Aulis and the Rhesus. The lines following verse 42 , where the real dream begins, form an integral part of the action. Iphigenia with the telling of her dream enters for the first time into her dramatic rôle.

${ }^{362} \mathrm{This}$ employment of a false interpretation of a dream to advance the action is, for the extant literature, an invention of Euripides. The source of the suggestion is conjectural. In Iliad, 2, $1 \mathrm{ff}$., the message of the dream is direct, without need of interpretation, and its essential falseness 


$$
\begin{aligned}
& \text {. . } \tau 0^{\circ} \nu \alpha \rho \delta^{\prime} \tilde{\omega} \delta \varepsilon \sigma u \mu \beta \alpha \alpha^{\prime} \lambda \lambda \omega \tau \delta \delta \varepsilon^{\circ}
\end{aligned}
$$

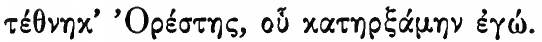

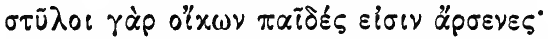

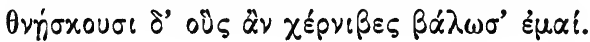

Her misinterpretation gives an atmosphere of somberness and foreboding to the play. This conclusion, previously reached, had moved her to summon her Greek fellow-captives and attendants of Artemis to aid in performing rites to the brother who, she is sure, is dead $(63 ; 138)$. Their delay in coming (64-66) clears the stage for the short scene between Orestes and Pylades $(67-122)$. Finally they enter in answer to her call (123) and ask the reason for the summons (137-142). Iphigenia breaks forth into lamentations: 'what a dream have I seen in the night of which the darkness has departed' (150-152). The chorus is asked to join her dirge for the dead, for that Orestes is no more she can entertain no doubts: compare her positive words $(156-158 ; 230-231):{ }^{363}$

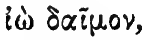

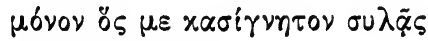

$$
\begin{aligned}
& \text { 'A } \delta \delta \alpha \tilde{\varepsilon} \mu \psi \alpha \varsigma, \text {. . . }
\end{aligned}
$$

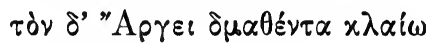

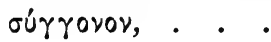

The chorus in joining in the dirge for the brother supposedly dead draws in still darker hues the tragedy of the house of Atreus (179-202).

(not a misinterpretation of it) causes many woes to the Greeks. So also the dream which the wily Pelias reports to Jason, Pindar, Pyth. 4, $163 \mathrm{ff}$., may have been looked upon by Euripides as an invention of the faithless monarch, that is, as a fictitious dream. Either of these dreams may have suggested the Euripidean conception of the false interpretation of a true dream. Or the hint may have been transferred from the realm of oracular responses, traditionally ambiguous, notoriously susceptible of conflicting interpretations.

${ }^{363} \mathrm{Cf}$. also $373-374,378-379$. 
This device of misinterpretation leads to a truly tragic situation; Iphigenia hardens her heart against the entrance of any human kindness when the capture of the stranger Greeks, Orestes and Pylades, is announced: as the result of the dream she will show no pity (348-350):

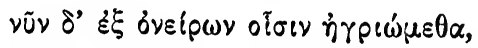

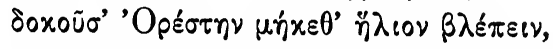

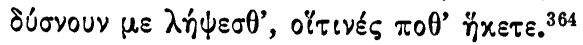

When the unrecognized Orestes tells her that her brother is not dead, she does not reinterpret the dream, but immediately declares it false (569):

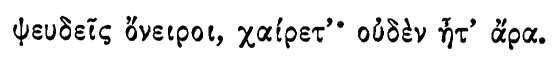

And Orestes, who has made all his moves under the influence of Apollo's oracle, in reply declares that Apollo is falser than winged dreams $(570-571)$ :

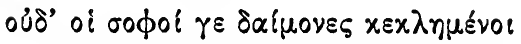

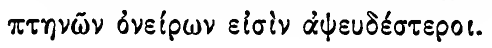

Here the two leading forces in the development of the action of the play up to this point, the dream, sent, as usual, to a woman, and the oracle delivered, as usual, to a man, are brought into contact, and both woman and man repudiate their former beliefs..$^{365}$ At this place all influence of the dream on the action ceases. ${ }^{366}$ The remainder of the plot, till the entrance of the

${ }^{364}$ See the entire speech beginning line 342 .

${ }^{365}$ Correctly interpreted, both dream and oracle are fulfilled. One may compare the similar fulfilment of the oracle in the Oedipus Tyrannus, 980-982, at which Jocasta scoffs.

${ }^{366}$ Staehlin's statement, p. 113, "Hätte Iphigeneia den Traum recht gedeutet, so dass sie in ihm nur eine Lebensgefahr für Orestes, nicht seinen schon erfolgten Tod gelesen hätte, so müsste sie wohl ohne weiteres in einem der beiden Griechen ihren Bruder erkennen", is without justification. The anagnorisis is not hastened by her early recognition that the dream has deceived her. The utmost effect of the misinterpretation is as I have stated it. 
$\theta \varepsilon \dot{s} \varsigma \dot{\alpha} \pi \dot{\partial} \mu \eta \chi \alpha \nu \tilde{\eta} s$, develops naturally from two factors: first, the interplay of character and situation, which turns the thoughts of the priestess toward home, and, secondly, the oracle of Loxias, which demands that the image of Artemis be carried to Athens. ${ }^{367}$

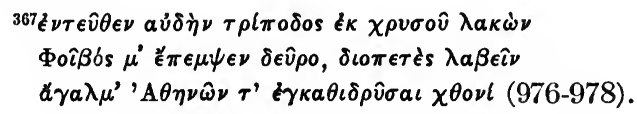

Those who, on the basis of the words of the chorus (1262 ff.), pronounce $\mathrm{Ge}$ the sender of the dream (see Paley's note ad loc. and the editors quoted there) unmistakably err. This chorus (1234 ff.) is connected with the rest of the play by a very slender thread, as is so common in Euripides. The oracle from Delphi which brought Orestes among the savage Taurians and exposed him to death - the oracle which he has thrice reproached as false $(77,570-$ $571,711 \mathrm{ff}$.) - not only has saved him when at the point of death, but has discovered for him a sister who, he thought, had been sacrificed. Hence the moment is well chosen to chant the glory of Apollo and his oracle (see Weil, Sept Trag., on this line). The chorus makes the subject of its lyric the fable of how the clear, bright divination of Apollo replaced the earlier chthonic incubation cult which had its seat at Delphi. The chorus tells the story of the strife. When Apollo had dispossessed Themis, the ancient prophetic goddess of Delphi, Earth, Faî, sent up to mortals prophetic dreams to rival the oracle of Apollo. Apollo appealed to Zeus and the latter deprived Gaia of this competing power (1262-1283). The import of this passage as symbolic of the triumph of a later over an earlier religion has been everywhere recognized (cf. Rohde, 2, 58: "Einst hatte $z \mathfrak{u}$ Pytho, über dem Felsspalt, aus dem der erregende Erddunst aufstieg, ein Orakel der Gaia bestanden, in dem vermutlich die Rathsuchenden durch nächtliche Wahrträume belehrt wurden [Eurip. Iph. Taur. $1230 \mathrm{ff}$.$] . Apoll setzte sich an die Stelle der Erdgöttin, hier wie an$ anderen Orakelstätte"; Hey, 22). But the factors which those who apply this story to the dream of Iphigenia have not recognized are two: (1) the strife is looked upon as in the past, so far in the past that the long-exiled chorus chants it as one of the famous legends of Apollo; hence the dream of the night preceding cannot be referred to this rivalry; (2) the dream of Iphigenia is not unfulfilled, only her misinterpretation of it is found to be incorrect. Hence Earth does not on this occasion send up a lying dream to balk Apollo. Indeed, Apollo took over, at least partially, the ancient practice of sending dreams till Asclepius assumed the incubation function. We can only say, then, that Euripides chose to leave the sender of the dream indeterminate. Apollo had replaced Gaia and it 
When we look at this dream as a dream, the first thing that strikes us is its elaboration; it is the most intricately and artistically fashioned of the dreams yet discussed. It may be divided into four episodes. First, there is the picture of Iphigenia, removed from the barbaric land of the Tauri and again restored to her native Argos, slumbering in the chamber ${ }^{368}$ in which she slept as a child (44-46). ${ }^{369}$ The second picture disturbs this idyllic scene with the panic and desolation of the earthquake. When the earth is shaken, Iphigenia rushes forth and turns to see the house falling, stone after stone, until but one pillar is left standing (46-51). The third episode introduces the element of the weird and the supernatural: the pillar is made man with yellow locks and human voice (51-52). In the fourth picture the stern reality of the horrid office of her waking hours breaks even into her slumbers. With tears she performs her priestly function, anointing the human victim for immolation. ${ }^{370}$

may be that he here sent the dream, also, which cooperated so well with his oracle to advance the action. This discussion is, of course, far more important from a philosophical, psychological standpoint; but it is also not without meaning in a survey of the elements entering into the use of a literary device which showed such a strong tendency to become stereotyped.

${ }^{268} \mathrm{I} \operatorname{read} \pi \alpha \rho \theta \epsilon \nu \hat{\omega} \sigma \iota \delta^{\prime} \epsilon \nu \mu \epsilon \sigma o \iota s ;$ see Weil's note in his critical appendix.

${ }^{869}$ The basic theory of the famous Viennese psychologist, Professor Sigmund Freud, is that the dream always represents the fulfilment of a wish. The conscious wish becomes a dream inciter only when it succeeds in arousing a similar unconscious one. In his view the wish as represented in the dream must, as a rule, be an infantile one. Iphigenia's dream of slumbering in the chamber where she slept as a child closely fulfils the terms of this formula. Cf. also supra, 47, n. 194.

s7oIt should be noted here that Iphigenia never performed the actual

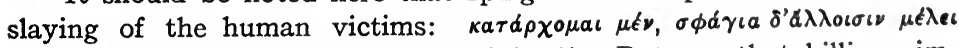

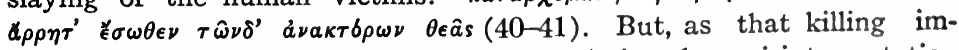
mediately followed her consecration of the victims, her misinterpretation of the dream was natural enough. Her impiety lay in declaring the dream false on the basis of this wholly unnecessary interpretation. 
This brief description shows how the internal technique of the dream is developing toward a greater complexity. The dream under discussion marks an advance toward the long and elaborate dreams which the later literatures developed. There is a romantic, a sentimental note, so beloved by the Alexandrians, ${ }^{371}$ in the picture of Iphigenia's sleeping again in the maiden quarters of her old home, a note which tends to arouse the pity and the sympathy of the audience. It is nearly related to the emotion aroused by the feeling of desertion and bewilderment which Ilia expresses in the Annales of Ennius. ${ }^{372}$ Euripidean technique wielded a strong influence among the Alexandrians ${ }^{373}$ and this highly complex and romantic dream was the forerunner of similar elements in the dreams of that later period. Other dreams were awe-inspiring or pity-arousing, perhaps, but only for their influence upon the rest of the story, externally so. Here the dream seems to acquire a personality of its own. It has a value and beauty independent of its connection with the story and of its meaning to the play. It differs from earlier dreams as a finished building differs from the architect's plan or a painting from a blocked-in sketch. It approximates the perfected and highly-chiselled miniatures in which the Alexandrian period delights. ${ }^{374}$ Tendencies are of long growth and obscure origin. One need not end his search for the eipétns of this type of Alexandrian love of intricate detail at Euripides. It is worth while, however, to call attention to its existence here in a dream for the first time in the extant poetry.

${ }^{371}$ Cf. Couat, 80 ff.; Ellis, xxxvii.

${ }^{372}$ Cicero, Div. 1, 20, 40; Vergil repeats the note in Dido's dreams, Aen.4, $465 \mathrm{ff}$. The dependence of Ennius upon the Alexandrians in respect of at least one type of dream I have attempted to demonstrate in another place; see above, n. 224.

${ }^{373}$ Cf. Couat, vi; 59; Ellis, xxxv; 278-279.

${ }^{374}$ Ellis, xxxvi ff.; Couat, 517 ff.; and the various Einleitungen and Schlussbemerkungen to the accounts of the different literary genres in the Inhalt of Susemihl. 


\section{The Rhesus}

The dream mentioned above ${ }^{375}$ as of lesser import, yet related in full, is found in the Rhesus (780-788). Homer had suggested it. Diomedes, he said, slew Rhesus

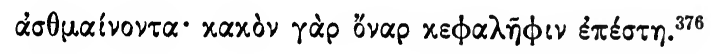

The Rhesus is the one extant tragedy the plot of which parallels an incident from the Iliad. Euripides assigns the dream to the charioteer - a change prompted, presumably, by the department of literature in which the poet is composing, since, otherwise, some such elaborate device as that found in the Hecuba would have been necessary to make the content of the dream known-and relates it in full..$^{377}$ The charioteer had discovered two men prowling about the camp. Thinking them petty plunderers he frightened them away and then lay down again and slept. In his sleep a vision stood at his side (780). ${ }^{378} \mathrm{He}$ beheld two wolves mounted upon the backs of the mares of Rhesus, where the driver usually sits. With their tails they lashed the horses till the steeds plunged and reared. The charioteer attempted to drive off the wolves, but the activity involved in the attempt and his fright aroused him from slumber.

This dream is interesting from many points of view. The Rhesus has been the subject of endless controversy. By some

${ }^{375}$ Supra, 85.

${ }^{376}$ Iliad, 10, 496. See the discussion of the technique of this dream supra, 9-12.

${ }^{377}$ On this point cf. my words supra, $56-59$, in regard to the changes in technique which the same dream may experience in its progress through the different literary types. In the story of the Iliad, Rhesus carried the subject-matter of the dream with him to the grave. Of course one predicates his statement of these changes on the basis of the extant literature. We are always at a disadvantage in discussing the source of a supposedly Homeric suggestion. In this case, for example, Euripides may be following some current Doloneia differing from Iliad 10, and perhaps even older than the version there given.

${ }^{378}$ See above, 6, n. 22. 
its authenticity has been assailed. By others, who have accepted the Rhesus as genuine, it has been assigned to various dates. Those critics who have discussed the play recently admit it, as a rule, to the Euripidean canon and consider it among the earliest of the plays of Euripides. ${ }^{378 a}$ With this decision the writer is inclined to agree. The older view tended to place the play late. The form of dream employed indicates either an early date for the Rhesus or else a conscious return to an earlier manner. For we find in the description of the dream many details which are reminiscent of the epic treatment. The position of the dream is given as in the earlier Homeric dreams ( $\pi \alpha p i \sigma \tau \alpha \tau \alpha$ l, 780). It appears to a male, as the dreams in the Iliad ${ }^{379}$ appear to males, whereas the conventional recipient of the dream in tragedy is a woman. ${ }^{380}$ It contains a simple allegory, as simple as the allegory of the geese and the eagle of Penelope's dream-the wolves which leap upon the backs of the mares are Odysseus and Diomedes of the Homeric story..$^{381}$ The charioteer's efforts to save the horses wake him as do Achilles' attempts to throw his arms about the phantom of Patroclus. ${ }^{382}$ Finally, in its general lack of complexity the description in the Rhesus approximates the epic norm.

In relation to any furthering of the plot, on the other hand, its kinship with the Homeric type of dream is very distant. ${ }^{383}$ The dream is added to the tale rather as an embellishment than

${ }^{378 a}$ W. N. Bates, Transactions of the American Philological Assoc., 47, 5, footnotes 1-3, gives the bibliographical clues to the older and the more recent views.

${ }^{379} 5,150 ; 10,496 ; 23,62$. ${ }^{380}$ Supra, 65, n. 253.

${ }^{381}$ Iliad, 10, 498-514. It will be recalled that Athene warned the heroes to leave before securing the chariot.

${ }^{382}$ Iliad, 23, 99-102.

${ }^{383}$ Care must be taken here to note that I am comparing the Homeric dream such as is related in full with the dream in the Rhesus similarly related in full. It is not my intent to compare the dream of the charioteer with the epic poet's mention, in passing, in one line, of the dream of Rhesus, Iliad, 10, 496. 
as an integral and necessary part of the story. For it is narrated well along toward the end of the play (at line 780; the play contains 996 lines) and even there is unimportant. It plays no rôle in influencing the action: dream and fulfilment are told within twenty lines (780-797). In the large it gives nothing to the play in the way of atmosphere, as do the dreams in the Choephori, the Persae, the Electra of Sophocles, and the Tauric Iphigenia. The suspense which the dramatic recital of the dream causes is too momentary to affect the play as a whole. The full function and purpose of this dream seem to be the minute elaboration and adornment of a detail.

All this is not without explanation. Rationalistic Euripides scarcely believed in the divine origin of dreams. ${ }^{384}$ He accepted the dream as a valuable artistic device. He was not averse, as a craftsman, to giving it a position of the utmost importance in advancing the plot. The Tauric Iphigenia illustrates this statement. But the dream had lost for him all that religious and artistic awe and sanctity which it had held for Aeschylus. It was to him an instrument to be used for any purpose which would serve artistic ends as he conceived them. Any idea of 'remembering the dream to keep it holy' was as foreign to his dramatic practice as to his philosophy. Euripides wanted an episode to give vividness and distinction to the narration of the messenger (for that is what the charioteer really is). This little prettiness could have been secured by other devices, of course, but the epic story suggested a dream. Our author, therefore, pitched upon a fairly simple epic type, the artlessly

${ }^{384} \mathrm{Hey}, 22$, who cites Hec. 69-70, Iph. Taur. 1262-1266, and Aristophanes, Frogs, 1331 (which levels ridicule, evidently at the head of Euripides, for over-doing the dream of horror), says: "Auch Euripides also ist wie Sokrates trotz seiner aufklärtılden Tendenz als traumgläubig zu betrachten (wenigstens in seinen Dramen), wenn wir auch bei ihm das spielerische Moment, das zum Teil eben in der Ubertreibung liegt, nicht verkennen wollen". The truth lies in his protasis rather than in his apodosis; see Staehlin, 217-218; P. Decharme, Euripide et l'esprit de son théatre, $95 \mathrm{ff}$. (Paris, 1893). 
allegorical, and used it in quite Alexandrian fashion for local adornment.

That the dream is effective in this small way no one can deny. But, however forcible it is in the context, this use of the dream to produce a momentary effect is a debasing of it from the high office which it filled in Euripides' fellow-poets. The overelaboration of details which came so much into vogue among Hellenistic writers had caught the dream too in its net. Euripides, so eminently the first of the Alexandrians in other respects, was here also the precursor of those who used the dream for small ends or unimportant prettinesses.

\section{Minor References}

The smaller references in Euripides to the dream are of natural frequency. I shall follow roughly the chronological order of the plays in noticing them.

Silenus, in the Cyclops, after boasting of his prowess in

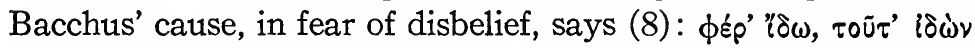
oैvap $\lambda \varepsilon \hat{\varepsilon} \gamma \omega$; Here dream experiences are looked upon as merely fanciful, existing only in the imagination.

In the Alcestis, Admetus, in his touching leave-taking from his wife, hopes that in dreams she may appear to him and cheer

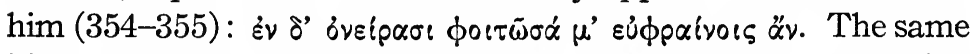
idea occurs in the Hercules Furens. Megara calls upon her husband to appear to her if only as a shade (494). She adds

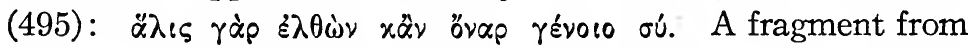
the Alope (Nauck 108) exhibits a like idea. ${ }^{385}$ In the Tauric Iphigenia the chorus of captive Greek women pray that they may see their native land and homes again if only in dreams $(452-455)$. And Orestes in the same tone wishes that he had never known Troy, not even in a dream (518).

In the Hercules Furens, the Theban ancients declare themselves, in view of their age, to be 'mere words, the gloomy-

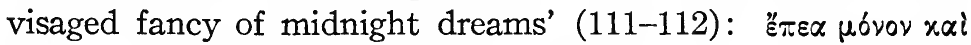

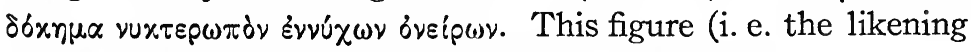

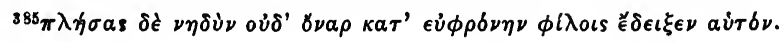


of the feebleness and helplessness of old age to a dream) is used by the chorus to excuse its inability, though loyal, to aid Megara and her children. It falls far short, however, of the beauty and startling unexpectedness of the phrase employed by the aged chorus of the Agamemnon (82) for a like purpose, ovap $\eta \mu \varepsilon \rho 6 \phi \alpha \nu \tau o \nu .{ }^{386}$ In two other places the dream is a synonym for the feebleness of age. Antigone, in the Phoenissae, leads forth her aged father, who calls himself a grey, unsubstantial wraith, 'a winged dream' (1545). This description the daughter recurs to when she calls him to her, 'like a dream in respect to strength' (1720-1722): $\tau \tilde{\alpha} \delta \varepsilon \tau \tilde{\alpha} \delta \varepsilon \beta \tilde{\alpha} \theta i \mu \circ \iota, \tau \tilde{\alpha} \delta \varepsilon \tau \tilde{\alpha} \delta \varepsilon \pi \delta \delta \alpha \tau \imath \theta \varepsilon i \varsigma, \omega ̆ \sigma \tau^{\prime}$ öveıov loxúv. In the Aeolus (fr. 25, Nauck) ${ }^{387}$ the old men say:

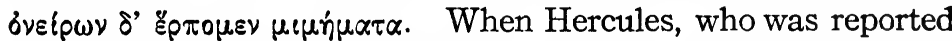
dead, suddenly appears, Megara is at first amazed, but, when immediately afterward she is convinced that Hercules is really come, she has recourse to the figure of the dream to express her conviction (516-519):

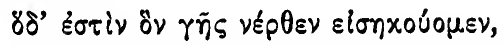

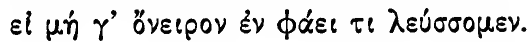

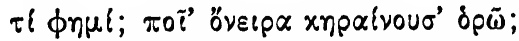

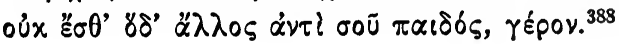

Tyndarus in the Orestes (615 ff.) turns his anger against Electra also, saying that she has incited Orestes by telling him the dreams sent up from beneath the earth by Agamemnon. This is a reference to the dream of Clytaemestra which had by this time become famous because it had been recounted by Aeschylus in his Choephori and, in modified form, by Sophocles in his Electra. Both these plays were produced long before the

${ }^{386}$ Supra, 78.

${ }^{387}$ Nauck, fr. 25, 3 (Leipzig, 1891).

${ }^{388} \mathrm{Paley}$ 's assignment of 517 to Amphritryon and his explanation of this passage are entirely indefensible. Heracles is not looked upon by Megara as appearing in a dream. After her first ejaculation of amazement, 514, she is aware that he has really returned in the flesh unless the impossible is true, as 517-518 mean 'How could I dream in broad daylight, especially anxious as I am?' 


\section{The Dream in Homer and Greek Tragedy}

Orestes. ${ }^{389}$ Euripides then in the Orestes makes a single reference in passing, as it were, to a well-known tale. ${ }^{390}$

In the Helena, Theoclymenus asks Helen whether she is groaning because of dreams she has seen by night (1190-1191):

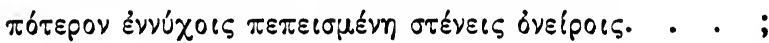

One more passage completes the list. In the Meleager (fr. 537, Nauck) the idea of Alcestis $692 \mathrm{ff}$., that life though short is sweet and death long and dreary, is repeated in the declaration that it is unpleasant for mortals even to dream of the darkness of Hades.

${ }^{389}$ The Choephori was produced 458 B. C., the Sophoclean Electra some time between 429 and 412, and the Orestes, 408 (see Christ, 1, 297, 331, and 354 respectively).

${ }^{390}$ Staehlin, 131, thinks that the dream referred to here must be different, asserting that not Clytaemestra, but Electra dreams. This inference is not necessary. Electra arouses her brother by interpreting to him her mother's evil dream. 


\section{LIST OF ABBREVIATIONS 1}

Ameis-Hentze = Ameis-Hentze. Homers Ilias ${ }^{3-6}$ (Leipzig, 18941906).
Anhang zu Homers Ilias ${ }^{2-8}$ (Leipzig, 1882-1900).
Homers Odyssee ${ }^{8-11}$ (Leipzig und Berlin, 1895-1901).
Anhang zu Homers Odyssees-4(Leip- zig, 1889-1900).

Aust $=$ E. Aust. Die Religion der Römer (Münster i. W., 1899).

Baumeister $=$ A. Baumeister. Denkmäler des klassischen Altertums

(München und Leipzig, 1885-1888).

Bekker = I. Bekker. Carmina Homerica (Bonn, 1858).

Bergk $=$ T. Bergk. Poetae Lyrici Graeci4 (Leipzig, 1878-1882).

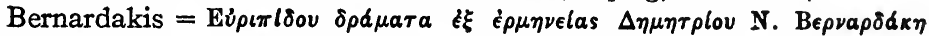
(Athens, 1894).

Boisacq = E. Boisacq. Dictionnaire étymologique de la langue grecque (Heidelberg and Paris, 1916).

Boissier $=$ G. Boissier. La religion romaine d' Auguste aux Antonins (Paris, 1874).

Bouché-Leclercq =A. Bouché-Leclercq. Histoire de la divination dans l'antiquité (Paris, 1879).

Buchholz = E. Buchholz . Die Homerischen Realien (Leipzig, 1881).

Büchsenschütz $=\mathrm{B}$. Büchsenschütz. Traum und Traumdeutung im Alterthume (Berlin, 1868).

Campbell = L. Campbell. Religion in Greek Literature (London and New York, 1898).

Cauer, Ilias $=$ P. Cauer. Homeri Ilias (Leipzig, 1890-1891).

Christ $=$ W. Christ. Geschichte der Griechischen Literatur ${ }^{5-6}$ (München, 1911-1913).

Christ, Ilias $=$ W. Christ. Homeri Iliadis Carmina (Leipzig, 1884).

Couat = A. Couat. La poésie alexandrine (Paris, 1882).

Croiset = A. and M. Croiset. An Abridged History of Greek Literature (English translation by G. Heffelbower, New York, 1904).

Cumont $=$ F. Cumont. Oriental Religions in Roman Paganism (English translation, Chicago, 1911).

De Marchi = A. De Marchi. Il culto privato di Roma antica (Milan, 1896).

${ }^{1}$ Where one abbreviation covers $t$ wo or more works (e. g. Ameis-Hentze), the particular work to which reference is made in any citation will be clear from the context. Except where otherwise indicated, I have used for Homer and Euripides the Oxford texts, for Aeschylus the Teubner text of Weil, and for Sophocles the text of Campbell. 
Deubner $=$ L. Deubner. De Incubatione Capita Quattuor (Leipzig, 1900).

Dieterich $=$ A. Dieterich. Kleine Schriften (Leipzig, 1911).

Dieterich, Nekyia = A. Dieterich. Nekyia. Beiträge zur Erklärung der neuentdeckten Petrusapokalypse ${ }^{2}$ (Leipzig, 1913).

Dill = S. Dill. Roman Society from Nero to Marcus Aurelius (London, 1905).

Düntzer $=$ H. Düntzer. Homers Ilias (Paderborn, 1866).

Dyer $=$ L. Dyer. Studies of the Gods in Greece (London, 1891).

Ellis = R. Ellis. A Commentary on Catullus ${ }^{2}$ (Oxford, 1889).

Eustathius = Eustathius. Commentarii ad Homeri Iliadem (ed. J. G.

Stallbaum, Leipzig, 1827-1829).

Commentarii ad Homeri Odysseam (ed. J. G.

Stallbaum, Leipzig, 1825-1826).

de Félice $=$ P. de Félice. L'autre monde (Paris, 1906).

Fick = A. Fick. Die Homerische Ilias (Göttingen, 1886).

Frazer, Belief in Immortality = J. G. Frazer. The Belief in Immortality (London, 1913).

Frazer, Golden Bough $=$ J. G. Frazer. The Golden Bough ${ }^{3}$ (London, 1911-1915).

Frazer, Pausanias = J. G. Frazer. Pausanias' Description of Greece ${ }^{2}$ (London, 1913).

Freud $=$ S. Freud. Die Traumdeutung 4 (Leipzig und Wien, 1914).

Gilbert = O. Gilbert. Griechische Götterlehre (Leipzig, 1898).

Gomperz, Greek Thinkers = T. Gomperz. Greek Thinkers (English translation by L. Magnus and G. G. Berry, New York, 1901-1911).

Gomperz, Essays = T. Gomperz. Essays und Erinnerungen (Stuttgart, 1905).

Granger = F. S. Granger. The Worship of the Romans (London, 1895). Hamilton = Mary Hamilton. Incubation (London, 1906).

Hardie $=$ W. R. Hardie. Lectures on Classical Subjects (London, 1903).

- Hey = F. O. Hey. Der Traumglaube der Antike (Programm des kgl. Realgymnasiums München, 1907-1908 [München, 1908]).

- Hey, Religion = F. O. Hey. Die Wurzeln der Griechischen Religion, in besonderem Zusammenhang mit dem Traumglauben (Programm des kgl. Gymnasiums in Neuburg, 1909-1910 [Neuburg a. D., 1910]).

$\mathrm{Jebb}=\mathrm{R}$. C. Jebb. The Electra of Sophocles (Cambridge, 1904).

Kaibel = G. Kaibel. Sophokles Elektra (Leipzig, 1896).

Kammer = E. Kammer. Die Einheit der Odyssee (Leipzig, 1873).

Kiessling-Heinze $=$ A. Kiessling-R. Heinze. Q. Horatius Flaccus. tiren $^{4}$ (Berlin, 1910).

Lang = A. Lang. Homer and his Age (London, 1906).

La Roche $=$ J. La Roche. Homeri Ilias (Leipzig, 1873).

Leaf $=$ W. Leaf. The Iliad ${ }^{2}$ (London, 1900-1902). 
Maury, Magie = L. F. A. Maury. La magie et l'astrologie dans l'antiquité et au moyen âge (Paris, 1860).

Messer $=$ W. S. Messer. Ad. Cic. Tusc. Disp. 3, 19, 45 (in Mnemosyne, N. S. $45,78-92)$.

Migne, P. G. = J. P. Migne. Patrologiae Cursus Completus. Series Graeca (Paris, 1854-1866).

Migne, P. L. = J. P. Migne. Patrologiae Cursus Completus. Series Latina (Paris, 1844-1880).

Nägelsbach, Ilias $=$ K. F. Nägelsbach. Anmerkungen zur Ilias (Nürnberg, 1864).

Nägelsbach, Hom. Theol. = K. F. Nägelsbach. Homerische Theologie ${ }^{2}$ (Nürnberg, 1861).

Nägelsbach, Nachhom. Theol. = K. F. Nägelsbach. Die Nachhomerische Theologie des Griechischen Volksglauben bis auf Alexander (Nürnberg, 1857).

Nestle $=\mathrm{W}$. Nestle. Die Weltanschauung 'des Aischylos (in Neue Jahrbücher für d. kl. Altertums, 19).

Norden $=\mathrm{E}$. Norden. Aeneis, Book vi2 (Leipzig, 1916).

Patin $=$ M. Patin. Études sur les tragiques grecs. Eschyle (Paris, 1890).

Preller-Robert = L. Preller-C. Robert. Griechische Mythologie (Ber- $^{4}$ lin, 1894).

Prellwitz $=$ W. Prellwitz. Etymologisches Wörterbuch der Griechischen Sprache (Göttingen, 1905).

Richter = P. Richter. Zur Dramaturgie des Äschylus (Leipzig, 1892).

Robert $=$ C. Robert. Thanatos. (Berlin, 1879).

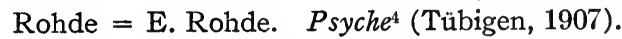

Roscher $=$ W. H. Roscher. Hermes der Windgott (Leipzig, 1878).

Seymour $=$ T. D. Seymour. Life in the Homeric Age (New York, 1907).

Spencer $=$ H. Spencer. The Principles of Sociology ${ }^{3}$ (New York 18991900).

Staehlin $=$ R. Staehlin. Das Motiv der Mantik im Antiken Drama (Giessen, 1912).

Susemihl = F. Susemihl. Geschichte der Griechischen Litteratur in der Alexandrinerzeit (Leipzig, 1892).

Tylor = E. B. Tylor. Primitive Culture (London, 1903).

Vahlen $=$ J. Vahlen. Ennianae Poesis Reliquiae ${ }^{2}$ (Leipzig, 1903).

Weil $=$ H. Weil. Étude sur le drame antique (Paris, 1897).

Weil, Sept Trag. $=$ H. Weil. Sept tragédies d'Euripides (Paris, 1905).

Zuretti $=$ C. O. Zuretti. Omero. L'Iliade (Torino, 1896-1905). 


\section{VITA}

William Stuart Messer, the writer of this dissertation, was born in Washington, District of Columbia, August 19, 1882. $\mathrm{He}$ was graduated from Columbia University with the degree of Bachelor of Arts in 1905. From the same institution he received the degree of Master of Arts in the year 1909. With the exception of a short residence at Yale University, his graduate work has been done entirely at his Alma Mater, where in 1909-1910 he was University Fellow in Classical Philology and in 19101911 Gottsberger Fellow in Classical Philology. In 1905-1909 he taught Latin and Greek in Barnard School, New York City. Since 1911 he has been Instructor in Classical Philology in Columbia University.

He has taken courses at Columbia University with Professors James C. Egbert, Roscoe Guernsey, Charles Knapp, Gonzalez Lodge, Nelson G. McCrea, George N. Olcott, Harry Thurston Peck, Edward D. Perry, James R. Wheeler, Clarence H. Young, and also with two distinguished visitors who conducted seminars or courses during his residence, Professors James S. Reid and Christian Huelsen. To all of these preceptors, and especially to those whom he met and under whose influence he fell during his undergraduate days, he owes no small measure of gratitude for their unfailing kindness and inspiration. To Professor Knapp, who has subjected this dissertation to his usual careful and judicious criticism, he can only tender his heartiest thanks, thereby adding himself to the ever increasing number of those who have given similar testimony in so many recent American text-books and dissertations in the field of Classical Philology. 

RETURN EDUCATION-PSYCHOLOGY LIBRARYO

IO $\rightarrow 2600$ Tolman Hall

\begin{tabular}{c|l|l}
\hline $\begin{array}{c}\text { LOAN PERIOD } 1 \\
\text { SEMESTER }\end{array}$ & 2 & 3 \\
\hline $\begin{array}{c}4 \text { SEMTESTER LOANM } \\
\text { NO TELEPHUNE }\end{array}$ & 5 & 6 \\
\hline
\end{tabular}

ALL BOOKS MAY BE RECALLED AFTER 7 DAYS

2-hour books must be renewed in person

Return to desk from which borrowed

\section{DUE AS STAMPED BELOW}

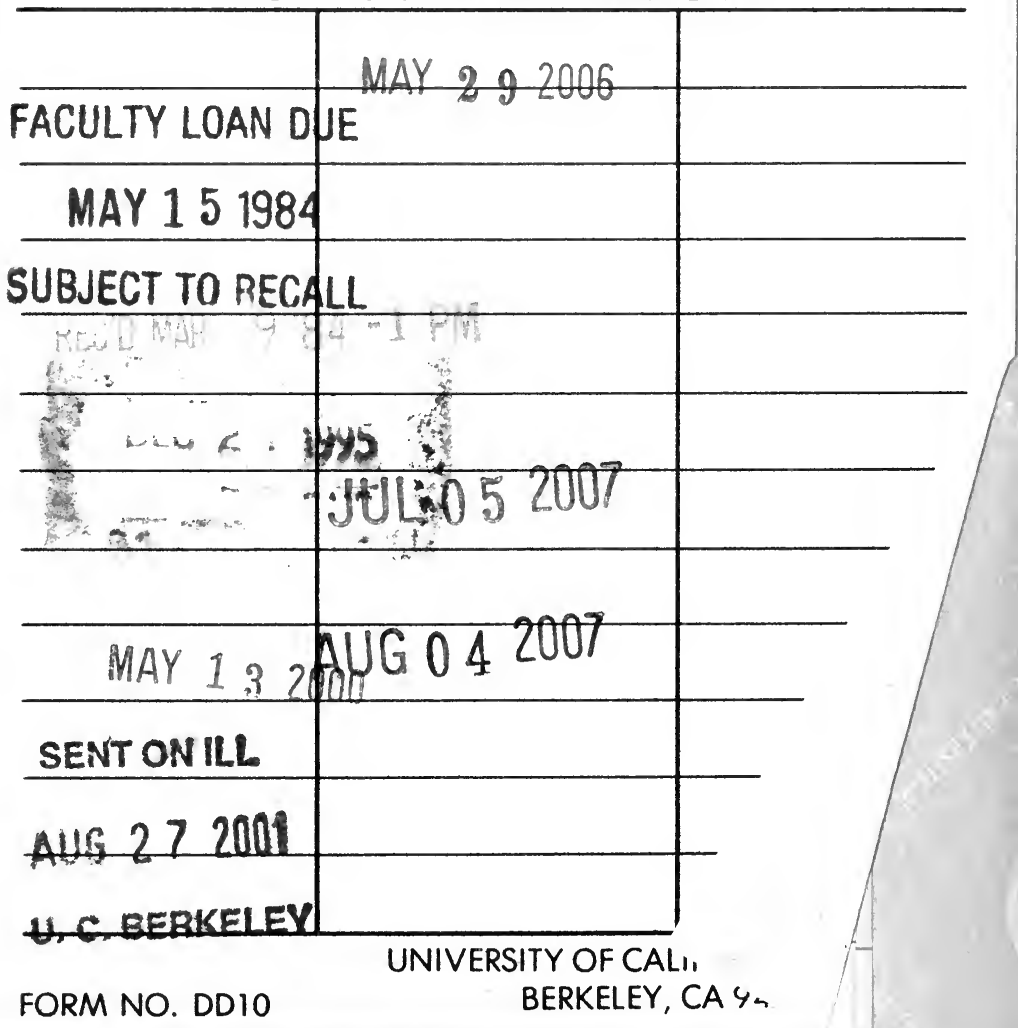




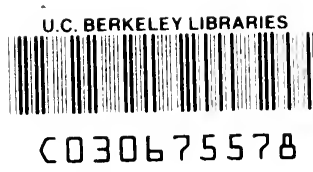


